\title{
The Language of Traditional Design*
}

\author{
Geleneksel Dizaynın Dili
}

\section{T. M. P. DUGGAN**}

\begin{abstract}
The article reasons that traditional Islamic design, in addition to the employment of scriptcalligraphy, was, and is at times still today, deliberately employed to serve as an aid to the practice of the remembrance of the Almighty and has both its origin and justification in the Holy Koran, as for example in Sura Al-'Ankabut, 29:46, "Nothing is greater than the remembrance of God". Remembering the Almighty within the man-made environment was traditionally addressed through the application to the surfaces of objects and structures of meaningful design that visually served as both direct-explicit and indirect-implicit reminders to this task, as the 'Word' is not to be forgotten and is to be seen, as well as spoken and heard, and there are its reminders, that is the employment of specific numbers, of colours, of a particular motif or range of motifs, individual letters, and of patterns in a design, and these meaningful designs also serve on a number of levels as aids towards, and reminders towards this remembrance. Some of the particular associations with the numbers from 1 to 10 , the number of sides to a particular tile shape, the repeating of the same motif or of a particular number of different motifs, of borders, of a number of different colours, each a particular number of times, are given; together with indications of the implications of an alphanumeric script for symbolism and for the practice of remembrance.
\end{abstract}

Keywords: Rememberance of God, Islamic Design, archangels, wav, tulip, donkey, star, crescent moon

Özet: Makale, hat sanatı-kaligrafinin kullanımına ek olarak geleneksel İslami dizaynın zaman içinde ve günümüzde Kadir-i Mutlağı yad etme pratiğine yardımcı bir işlevi yerine getirmek amacıyla bilinçli olarak uygulandığı ve hem orijinini hem de gerekçesini örneğin Al-“Ankabut Suresi’ndeki (29:46) "Hiçbir şey Allahın zikredilmesinden daha yüce değildir” ifadesinde olduğu gibi Kuran-ı Kerim'den aldığı sonucuna varır. İnsan işi ortam içinde Kadir-i Mutlağı hatırlama eylemi geleneksel olarak objelerin ve yapıların yüzeylerine bu görevi görsel açıdan hem doğrudan-açık ve hem de dolaylı-örtük bir şekilde yansıtan anlam yüklü dizaynın uygulanması şeklinde oluyordu. Böylelik 'Söz' konuşulması ve işitilmesinin yanı sıra aynı zamanda unutulmayacak ve görülecektir. Ve 'Söz'ün hatırlatıcıları da spesifik sayıların, renklerin, belirli bir motifin ya da motifler dizisinin, tek tek harflerin ve şablonların bir dizayn içinde uygulanmasıdır. Bu anlamlı dizaynlar birkaç seviyede yad etmenin yardımcıları ve hatırlatıcıları olma misyonunu da yerine getirir. Örneğin kenarların sayısından belirli bir çini şekline, aynı motifin veya belirli sayıdaki farklı motiflerin, bordürlerin, birkaç farklı rengin her biri belirli sıklıkta olmak üzere tekrarlanmasına kadar 1-10 arasındaki sayılarla oluşturulan bir kısım özel çağrışımlar sembolizm ve yad etme pratiği için alfanümerik bir yazıya ilişkin imalara yönelik göstergelerle birlikte verilmektedir.

Anahtar Sözcükler: Zikr, Geleneksel Süsleme Sanatı, başmelek, ve (vav), lale, eşek, yıldız, hilal

\footnotetext{
* The first version of this paper was given at the Organisation of the Islamic Conference (OIC) Research Center for Islamic History, Art and Culture (IRCICA), bi-monthly lecture at the Çit Qasr, Yıldız Palace, Beşiktaş, İstanbul, June $24^{\text {th }}$, 2000. A second version of this paper was given at Doğuş University, Istanbul in May 2003.

** Sanat Tarihçi, Akdeniz Üniversitesi, Akdeniz Uygarlıkları Araştırma Enstitüsü, Antalya, tmpduggan@yahoo.com I have been fortunate in receiving the assistance of A. Akçay and A. Aygün in the preparation of some of the visual material in this article.
} 
There is a fundamental purpose to the use of design, pattern and motif in works of Islamic art, regardless of period and place. This purpose is to take a worldly material - a plain stone and mortar wall, a bare clay pot or tile, a sheet of copper, a piece of timber, or the warp and weft of a carpet, kilim or textile - any raw material surface; and to remove its appearance as a worldly or material substance through the application to it of design, of a literally 'meaningful' pattern. The results of this action transform the manmade environment within which a person lives from being an environment of base material into an environment of base material which has been ennobled by design.

\section{Why?}

The pattern of a design dissolves the material nature of our man-made world and so can release the inhabitant from the bondage of the temporal, of the material world and can free the contemplative person from the distractions of this place. Thus design permits the spirit to ignore the base material substance - the raw material of the objects and buildings of our temporal world - and instead, to de-couple and thereby to obtain the opportunity within the manmade environment to focus upon another order of living.

There is a Barakah, a blessing, to the natural world and a Barakah is likewise to be obtained from works made in the traditional manner which carry their clothing of meaningful pattern and design and where the raw material and naked functional use of an object is dressed in meaningful number, pattern, motif and design. The use of these designs is a richness of much importance to the well-being of the community, as through covering raw material with meaningful design we are thereby provided within our man made surroundings and on the surface of the items employed in our everyday life, with the necessary material for contemplation and can be reminded of our true nature as people when we otherwise become distracted, trapped and lost within the world of raw material, ensnared by the material world.

This is no longer the case in our naked modern man-made environment where surfaces may be polished, coloured or raw, depending on the fashion of the moment, but where the patterns of meaningful design, relating to the submission to, and the consequent need for the remembrance of the Almighty, are typically missing from the modern man-made environment.

Within the designs, script, patterns, colours, numbers and motifs to be found on the manmade artefacts produced in the lands inhabited by traditional Islamic society are the signs and indications to permit, to enable and to invite us to join in an other-worldly remembrance and recitation. The objects, materials and buildings ennobled by their garment of design, colour and meaningful symbolism are a tangible and visible reminder, both on a conscious and at a subliminal level of our human situation and of its duties. To live everyday within this traditional environment, filled with design and pattern, from carpets, kilims and textiles to decorated ceramics, metalwork and carved and painted wood and stucco-work, is to inhabit this temporal physical world but not necessarily to be a part of it - that is, to be in this world but not to be of this world (From the hadith, "The Messenger of God said, "Be in the world as if you were a stranger, or a wayfarer". Hence the caravanserai of the world, only a brief or lengthy stopping place, a halt on the journey). This is because the surface of the materials clothing and surrounding the person have been reworked and covered by both explicit and also by more subtle reminders towards the remembrance of the Almighty.

The designs, patterns and symbolism used in this practice of embellishment are structured to create an even, although not a static balance, both over the whole of a carpet, building, vase, plate, tile or kaftan, and, on a much smaller scale, with the individual elements of the pattern, between the empty or plain areas and the pattern, motif or script - the balance between the presence and the absence, the script and the void, reminders of the Real and the only relatively 
real. As also between the different planes of the areas of pure colours employed. Are the areas of turquoise blue, in front of, or level with, or behind those areas of cobalt blue, of red, of yellow, of green, of black and of white? As with a mashrabiya - kafes, a screen, or with the veil of this temporal world, is it the pattern and the shape of the bars of the screen itself which are of lesser, or are of the same importance, or of a greater importance, being visually and it appears physically closer than the spaces between them, although the Almighty is in reality closer to one's self, than ones' own jugular vein (Eg. Holy Koran Sura Qaf, 50:16), the screenmashrabiya being an analogy to this world and the greater world, of worlds within worlds, a matter of the individual's particular visual and spiritual orientation and focus; as well as the screen serving the practical function of providing diffuse lighting and a degree of seclusion.

As God's vice-regent on earth, the created man has great need of meaningful pattern, of thought through design, which serves to remind within the manmade environment of the majesty of creation and of the "Great Designer" or Nakkaş (The Arabic words hattat, calligrapher, nakkaş, designer/decorator, and mühendis, geometrician-engineer, contain within them the meaning to design, as script can be a pattern and as pattern can be read like a language, as an engineer was trained in geometry before employing it in the construction of a building), The Almighty, - Al Sattar- who both veils through the act of Creation and, through this veiling, both conceals and at the same time reveals this truth. A design likewise, be it painted or woven, moulded or cast, embossed or punched, embroidered or engraved, carved or inlaid, is the result of an activity which both conceals the raw material and reveals a different vision, a reorientation away from the purely material, as does script - like night and day, light and shade, ink and paper. Islamic design serves within the manmade environment as a sign, a reminder of the signs visible in the natural world and in ourselves, as recorded in the Holy Koran with its numerous references to the "signs of God", as for example:

1) In Sura Fussilat, 41:53, "We will show them Our signs in all the regions of the earth and in their own souls, until they clearly see this is the truth".

2) In Sura Al-Dhariyat, 51:22, "On earth and in yourselves there are signs for firm believers. Can you not see them?”.

Signs such as the diversity of colors and languages, as recorded in the Sura Al-Rum, 30:22, "Among His other signs are the creation of the heavens and the earth, and the diversity of your tongues and colors. Surely there are signs in this for all mankind".

Muhammad ibn-i Munawwar, the grandson of Abu Sa'id ibn Abi'l Khayr (d.1049), in his Asrar al-Tawhid, (The secret of God's Mystical Oneness) remarks on the function of the spiritually awake, that: "They may turn men at large from the world of appearances to the world of higher meaning" (J. Renard, Seven Door to Islam-Spirituality and the religious life of Muslims, University of California Press, Berkley and London, 1996, 82).

And Islamic design serves this same function, by both dissolving away this 'world of appearances,' this world of temporal appearance and of material substance, of conditional reality, through the application of meaningful pattern, and through the use of symbolism rooted in revelation in the design of both patterns and motif, articulates in an explicit and also in an implicit fashion, the call to attend upon God, to attend 'to the world of higher meaning', that is, to the everyday waking task of the remembrance of the Creator, the Almighty.

The explicit symbolism is calligraphy - The Names of God, words, parts or whole Sura of the Holy Koran, hadith, invocations, script and letters - bound up within a design and often acting as punctuation to the overall pattern(s) clothing a building, lamp, ewer or brocade (Figs 1-3).

However, implicit symbolism forms the largest quantity of Islamic design and these designs can operate on a number of levels of meaning, as is likewise the case with literary symbolism, 
and can serve as a reminder of the fact that, "God speaks in metaphors to men" (Holy Koran, Sura Al-Nur, 24:35).

Firstly, as the expression of praise, given definition by detail, mastery of execution, balance and beauty, as an exhibition of servant hood, Islamic design does not attempt to rival the Creator, but instead shows due restraint in reflection.

Secondly, in consequence of the particular use by a designer of signs, symbols and numbers (of particular motifs or parts thereof as also in the number of the colours employed), a whole panorama of significance to the informed intellect of the observer can be brought to mind. It is this point at which it becomes a matter of what the individual - the viewer knows - that establishes the level, or the vocabulary of understanding, of what one can perceive of the meaning that is contained within a motif, a pattern or a design. This is a blessing of inclusion rather than exclusion, in that one can comment on the colours, their range, number and variety, the form of the pattern, its wonder and intricacy and at the craftsmanship and the materials employed, without necessarily being aware that the particular design employed itself carries a meaning or sense, nor of what this meaning or combination of meanings may be. This is because, like the use of ishara - of allusion in literature, this implicit symbolism operates by alluding to a framework of Islamic knowledge, and thus the depth of this symbolism is dependent upon the extent of the education, knowledge and the time that the particular individual is able to bring to the veil of design. This veil of traditional design covering the surface of the raw material is not to be exhausted by a glance, by a brief look - nor yet by years of study, while the reservoir of meaning contained within a traditional Islamic design is replenished and grows with the time, thought, education, experience and the knowledge that is at the disposal of the viewer. The levels and layers of meaning within a thought-through and meaningful Islamic design call to mind the range of meanings between As-Zahir - The Outward and Al-Bartin - The Inward.

Ibn Qutayba in his kitabu'l ma'arif of 898, 285 hijra, records the knowledge that was required to understand the court poetry at that time, and thereby provides us with some indication of the associations, the intellectual climate, within which the $9^{\text {th }}$ c. Islamic court tirazhane and court based design studios operated. He gives, in addition to knowledge of the Holy Koran, the Hadith, of Arabic and of other languages, a list of the knowledge of the following subjects which was required for a person to be considered educated and for that person to be able to understand the various symbolic meanings and references made to this body of knowledge shared by the educated courtier-nadim, and which was referred to and was reflected by $9^{\text {th }}$ c. court poets in their poetry, and it is aspects of this cultural climate that are reflected in the works that were produced by the palace-court design studios in Bagdad, at Samarra, as elsewhere:

"The Creation, Sacred history, Prophets and Patriarchs in the Old Testament and the Koran and Christ. The history, chronology and racial divisions of mankind, true believing Arabs before the Prophet of Islam, genealogies of the Arabs, genealogy and kinsfolk of the Prophet, his wives, children, clients and horses. The history of his mission, wars, triumph and death. The history of the first four Caliphs, of Ali's sons, of Zubayr, Talha, Abdurrahman b. 'Awf, Sa'd b. Abi Waqqas and other eminent Muslims of earlier times concluding with a list of Hypocrites. The history of the Umayyad and Abbasid Caliphs, biographies of famous statesmen, officers and governors of the Islamic world and of notable rebels. The Successors to the Companions of the Prophet, the biographies of the chief doctors and teachers of Islam, of the founders of its principle 
schools of thought, of the traditionalists, the readers of the Koran, geneologists and historians, grammarians and transmitters of Verses (Sura and hadith) etc., of the principle mosques, of the early conquests of the Muslims and of other matters concerning them, of the chief outbreaks of plagues and pestilence, of the battles of the Arabs, of their religions before the time of Islam, of the chief sects of Islam, of the way for example Kurds and Jews came by their names, of the histories of the Kings of Yemen, Syria, Hira and Persia from the time of Jamshid to the end of the Sassanid dynasty and (also) technical knowledge: the science of ideas and expressions, euphuism, so he will recognise similies, metaphors, innuendo, hyperbole. Antithesis, quotations, aetiologies, amphibologies, homonomies, anagrams and tropes" (Browne, 1997, 387-89).

It is this knowledge which formed the extent and parameters of the cultural climate at court current at that time and to which reference would need to be made in any serious attempt to understand the cultural context of palace works of art and the copies thereof, and the meaning(s) these works conveyed to their audience of educated contemporaries. Not therefore any matter of like or dislike, nor of personal taste, but rather a matter of the possession of a particular education (For further examples of the particular range of knowledge required of a courtier within this court context, see for the $12^{\text {th }}-13^{\text {th }}$ c. as is recorded in the work Ravendi, 1999, or as earlier, by Muhammad b. Ishaq an-Nadim in his Fihrist of 987-8, Browne, 1997, 387-389; or earlier of the slave girl called Sympathy at the time of the Caliph Harun al-Rashid, or later, recorded in the Tale of Sympathy the Learned, in, Mardrus, \& Mathers, 1996, 142-169) and of this particular knowledge informing understanding and having a quite particular importance, given the status awarded to the possessors of knowledge at court and in society, both settled and nomadic, in the Islamic world down to the present day.

Thirdly, by concealing the raw material of an object through design, the symbolism of God The Concealer and The Revealer - is itself repeatedly hinted at through every act of design carried out by a master designer and which a master craftsman executes. Islamic design and pattern can be understood to serve as both a reminder of meaning and as a reminder of The Designer of the universe, of the worlds within worlds, but in a manner somewhat different from script.

Fourthly, there is fact that colours are themselves to be read as a sign of the Almighty in the world, as for example is recorded in the Holy Koran Sura Al-Nahl, 16:13, "On the earth He has fashioned for you objects of various hues".

The colours themselves are mentioned as given by the Creator in the Holy Koran Sura AlFatir, 35: 27, "Did you not see how God sent down water from the sky with which We brought forth fruits of different hues? In the mountains there are streaks of various shades of red and white, and jet black rocks. Men, beasts and cattle have their different colours, too".

It seems probable that the choice of red, white and black for the colours employed in colouring of the designs on many carpets, woven for example in North Africa, in some Turkish heybe, and in some Afghan Ersari (For example, Bennett, 1977, 117), was a consequence, not of any random or fanciful choice, nor because of the availability of only these three colours as dyes, but because of a quite deliberate and considered choice, based upon these three colours, red, white and black, being named in this Ayet of the Sura Al-Fatir - The Creator, for the weaving of carpets in these three colours and, in consequence, these three colours woven on these carpets and flat-weaves can be "read" and can be understood to carry a meaning, serving as a visual reminder both of this particular Ayet and, through this verse, of The Creator, of the Almighty. 
Yet further, there is the deep matter of the meaning contained within the Holy Koran Sura Al-Baqarah, 2: 138, which raises the whole matter dyes and of colour, of colour symbolism and of reflective and transparent surfaces within an Islamic context: "We take on God's own dye. And who has a better dye than God's! Him will we worship".

This Ayet was not only of importance in respect to the repetition of, reflecting upon and absorbing to the individual's particular capacity, the Names of God, thereby dyeing the soul of the person with the Names of the Almighty through "dhikr Allah"; but also in the physical matter of the production of coloured dyes, of the choices made in their use in textiles, on parchment and paper, of staining, of colour and colour symbolism. This Ayet may not only have motivated and given support to the weaving of certain highly valued, reflecting, transparent and iridescent cloths, as for example produced in the tirazhane at Tinnis in Egypt, as elsewhere, where cloth such as was, "called Bukalamun (Chameleon, the textile named after the light sensitive skin of the creature), the color of which changes according to the hour of the day" was woven; (Serjeant, 1972, 142) as well as probably having an impact upon the support for the development of, and for the use of gold dissolved in mercury in gilding, as also in the invention, support for and employment of lustre on Islamic ceramics (See for example, Caiger-Smith, 1985, as for example the use of luster tiles around the mihrab of the Great Mosque at Kairouan, Tunisia) for iridescent glazes, for reflective pools of mercury in palaces, (As in the palace of Khumarawayh , 884-95) in Old Cairo, where air filled leather cushions, moored by siken ropes to silver columns, supported the Sultan and others as they floated on this pool of mercury, Hitti, 1991, 454; and at the $10^{\text {th }}$ century palace of al-Madina al-Zahra, by Cordoba, Irwin, 1997, 121), for the use of mirror glass, as also for the production of enamelled glass in Egypt, Syria, Turkey and elsewhere, as is also indicated in the famous story of the competition between the Rum (East Roman) and Chinese painters at court, where the polish, the reflection, the reflected image, rather than the application of the paint itself, gave the victory to the Chinese over the East Romans (The contest between the Chinese and the Rum is recorded in Nizami's Iskandername of 1200 and cited in Arnold, 1965, 67-8. For the practice at court of contests between renowned artists from different places see the Fatimid mid- $11^{\text {th }}$ c. example cited in Arnold, 1965, 21-2; between an Egyptian and an Iraqi. Jelalad-Din Rumi remarks in Discourse 10 of the Fihi ma Fihi: "For the mirror is without any image of itself; if an image shows in the mirror, it is an image of another.", and to the numerous references in Islamic mystical literature to "polishing the mirror of the heart". In the Mathnavi, Book 1, verse $3469 \mathrm{ff}$, the positions are reversed, with the Chinese painting and the Rum-Greeks, polishing the mirror: "The Chinese said, "We are the better artists"; the Greeks said, "The (superiority in) power and excellence belongs to us". "I will put you to the test in this matter", said the Sultan, "(and see) which of you are approved of in your claim". The Chinese and the Greeks began to debate: the Greeks retired from the debate. (Then) the Chinese said, "Hand over to us a particular room, and (let there be) one for you (as well)". There were two rooms with door facing door: the Chinese took one, the Greeks the other. The Chinese requested the Sultan to give them 100 colours: the Sultan opened his treasury that they might receive that (which they sought). Every morning, by (his) bounty, the colours were dispensed from the treasury to the Chinese. The Greeks said, "No tints and colours are proper for our work, nothing (is needed) except to remove the rust". They shut the door and went on burnishing (the walls): they became clear and pure like the sky. There is a way from many colours to colourlessness: colour is like the clouds and colourlessness is like the moon. Whatsoever light and splendour you see in the clouds, know that it comes from the stars and the moon and the sun. When the Chinese finished their work, they were beating drums for joy. The king entered and saw the pictures there: that (sight), as he encountered it, was robbing him of his wits. After that, he came towards the Greeks: they removed the intervening curtain. The reflection of those (Chinese) pictures and works (of art) struck upon 
these walls that had been made pure (from stain). All that he had seen in there (in the Chinese room) seemed more beautiful here; 'twas snatching the eye from the socket"), and which seems to indicate the importance given at that time to the world of archetypes and of their reflection in the temporal world, as for example later Jelad-Din Rumi clearly expresses when he writes of this imaginal world of archetypes in his Divan Shams-i Tabriz:

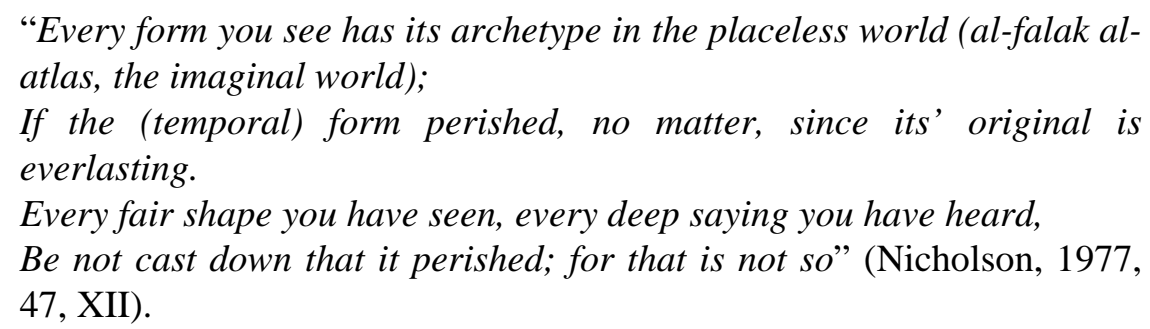

The patterns, motif and colour forming these designs are invaluable man-made signs, supports and man-made reminders of the path through this temporal world within the manmade environment. This is because one can, as T. S. Eliot wrote, be distracted from distraction by distraction (From the first of T. S. Eliot's Four Quartets, Burnt Norton III; “Neither plenitude nor vacancy. Only a flicker / Over the strained time-ridden faces / Distracted from distraction by distraction / Filled with fancies and empty of meaning / Tumid apathy with no concentration / Men and bits of paper, whirled by the cold wind "), but in this context meaning that one can be refocused from the distractions of this place, this temporal material world, through the remembrance of another world, as Majnun was distracted from this temporal world through the remembrance of Leyla, with this remembrance for the believer facilitated by these man-made signs and these reminders deliberately placed by designers within the man-made environment; as one can be struck in nature, and stop and wonder at the light on a leaf, at an empty landscape, at the series of three, five and seven leaflets below the rose bud on some rose bushes (Fig. 1), at the segments of a fruit, and count them, attend to the design of a sea shell, the pattern on the rind of a water melon, the veins on the underside of a leaf, at the distribution of seeds in a fruit, or at a vista between the black trunks and branches of trees, and so be reminded of the Almighty through the design and designs of the Creator in the natural world, Holy Koran Sura Al-Shura, 42:29, "Among His signs is the creation of the heavens and earth, and the living things which He has dispersed over them".

Fifthly, there is the serious matter of idolatry of the script, and the self-evident fact that the Word of God, recited and in script, the Arabic Koran ("We have revealed the Koran in the Arabic tongue so that you may grow in understanding". Sura Yusuf 12:1: "Thus have We revealed it, A code of judgements in the Arabic tongue". Sura Al-Hijr 15:38; "We know they say: 'A mortal taught him'. But the man to whom they allude speaks a foreign tongue, while this is eloquent Arabic speech". Sura Al-Nahl 16:103; "We have revealed to you the Koran in your own tongue that you may thereby proclaim good tidings to the upright and give warning to a contentious nation". Sura Maryam 19:97; "Thus have We sent it down: a Koran in the Arabic tongue, and proclaimed in it warnings and threats so that they may take heed and be admonished ". Sura Ta Ha 20:113: "The faithful Spirit brought it down into your heart, that you might warn mankind in plain Arabic speech". Sura Al-Shu'ara 26:193: "A Koran in the Arabic tongue, free from any flaw, that they may guard themselves against evil”. Sura Al-Zumar 39:27: "Thus have We revealed to you an Arabic Koran," Al-Shura 42:7; "By the Glorious Book! We have revealed the Koran in the Arabic tongue that you may understand its meaning. It is a transcript of the eternal book in Our keeping, sublime and full of wisdom". Sura Al-Zukhruf 43:1-5; "It is revealed in the Arabic tongue, to forewarn the wrongdoers and to give good tidings to the righteous". Sura Al-Ahqaf 46:13), represents, and, as the link between the 
Almighty and man, is to be honoured, but it is not to be confused with the Almighty ("By the Glorious Book! We have revealed the Koran in the Arabic tongue that you may understand its meaning. It is a transcript of the eternal book in Our keeping, sublime and full of wisdom." Sura Al-Zukhruf, 43:1-5), to that to which all worship is to be directed (Idolatry is stated in the Holy Koran to be the one sin that the Almighty will not forgive, Sura 4, Al-Nisa: 116; and that "Idolatry is worse than carnage", Sura Al-Baqarah 2:191-4; also Sura Al-Ahqaf 46:5; Sura AlNahl 16:20-21 and 73; and Sura Al-A'raf 7:190-200). This matter formed an implicit part of the long lasting dispute concerning the created or the uncreated nature of the Holy Koran, the Umayyad Caliph Hisham (724-43) ordered the execution of al-Ja'd ibn-Dirham in 741 and Jahm bin Safwan in 745 for teaching that the Koran was created (Hitti ,1991, 430), which continued in the dispute between those who in the $9^{\text {th }}$ c. called themselves the ahl al-'adl wa al-tawhid (People of the Divine Justice and Unity), and who advocated, amongst other things, the created nature of the Holy Koran (Bishr al-Marisi in 803 advocated it and was in consequence thrown out of the lecture hall in Bagdad. See for example the references to this matter in, Jokisch, B. 2007), and who were called in consequence by their opponents, Mu'tazila (Withdrawers-from Islam), but who were supported by some Abbasid Caliphs in the $9^{\text {th }}$ c., including the Caliph alMa'mun (813-33) who proclaimed in 827 the belief that the Koran was created, khalq alQur'ann, as distinct from the view that it was an exact copy of a celestial original, and who in 833 decreed that no kadi-judge could be appointed to office who did not believe in the created Koran, and he was the Caliph who instituted the mihnah to bring to trial all those who denied this official belief in the created Koran, a policy which was continued by his two successors, the Caliphs al-Mu'tasim (833-42) and al-Wathiq (842-47), under whom the ahl al-'adl wa altawhid view of the created Koran remained Caliphal policy, leading to the failed uprising in Bagdad led by Ahmad ibn Nasr against this policy in 846. In its implications it has been the most important internal dispute in the Islamic world, of more consequence than the split caused by the still on-going dispute concerning the legitimacy of the succession to the Caliphate in the $7^{\text {th }}$ c. This second internal dispute during its course caused the foundation of the Hanbali school of law, Ahmad ibn Hanbal being the most public opponent of the ahl al-'adl wa al-tawhid policy of the Caliph al-Ma'mun (To whom and his followers the Wahabi and Salafists of today trace their stance), and which for some was resolved by the Caliph al-Mutawakkil (847-61) who reversed in the second year of his reign the ahl al-'adl wa al-tawhid policy of the Abbasid Caliphate and who, in 850 decreed the death penalty for anyone who taught that the Word of God is created, and who in 851 ordered the demolition the tomb of Husain at Karbala, and which was resolved for many more through the formulation developed by al-Ash'ari (d. 935) amongst others, and which became widespread, propagated as official policy as a consequence of the Great Seljuk largely Shafi-Asharite anti-batini and anti-Fatimid policy from the $11^{\text {th }} \mathrm{c}$. onwards, particularly through the work of the scholar Muhammed al-Ghazzali (1058-1111) and the teaching provided at the Nizamiyya medrese system established from the $11^{\text {th }}$ c. onwards in Sunni territory. The Sunni formulation reached was: "that the Koran is God's uncreated Word, but the writing or sounds by which men have access to it are created things" Williams, 1962, 189; and somewhat modified from Ahmad ibn Hanbal's, "Nothing which is of God is created and the Qur'an is of God", cited in Black, 2001, 37). There is implicit within this long lasting dispute, the script being the invaluable reminder of and guide to the Truth, that the written script itself would become the focus-object of worship, which would be idolatry, unless the Word was itself co-eternal with the Almighty that is it is uncreated and so immutable (The find of early Koran texts from the Yemen, together with historical and textual issues raised recently in various publications denying the immutability of the text and consequently questioning belief in the uncreated Koran, in addition to the abrogated verses, and those verses that are reported as missing, eg. Peters, 1994, 247, in reference to Umar's relation; as also the absence of diacritical 
marks in early copies of the text, indicate this dispute will continue into the foreseeable future and God knows best). The importance of this dispute for aspects of Islamic art is apparent, for example in respect to the use of script on carpets and kilims which might well be walked or sat upon, the formerly common use of explicit text woven in them seems to have been greatly reduced from the $14^{\text {th }}$ c. onwards, a consequence of fatwa issued by Hanbalite scholars concerning this matter (see below), combined with the great reduction of the state tirazhane system itself, a source of carpets as well as textiles carrying inscriptions, although not of tiraz, following the Pagan Mongol sack of Bagdad and the execution of the Abbasid Caliph in 1258 (Although some state tiraz continued to be produced, as for example the surviving example probably from the reign of Sultan Yıldırım Beyazıt 1389-1402, carrying the name Bayazid Khan in the Studenica Monastery, Bosnia, Blair, 1998, 176).

\section{The Centres of Design}

The prestige of Islam in the world, distinguished by its script and designs, has been considered as being a matter of very great importance, of state importance by rulers from the mid- $7^{\text {th }} \mathrm{c}$. onwards (As for example when questioned about ostentatious display in the East Roman manner, the Umayyad Caliph Mu'awiya, 661-680, remarked, 'I desire to rival the enemy in martial pomp, so that he may be witness to the prestige of Islam', cited in Hillenbrand, 1999, 16-17) until the state design institution's decline, with the decline of the Ottoman nakkasshane (places for the creation of works of design), and its final closure in the $19^{\text {th }}$ c. by the reforming Ottoman Sultan Mahmud II. The centres from which much Islamic design has originated have been those palace nakkaşhane which, at various times and places have been of paramount importance in developing variations of design and types of patterns and modes of expression. The modulations of style, that distinguish for example Abbasid from Fatimid, Ottoman from Safavid, or Mamluk from Seljuk works of art have their origin in the exemplary work carried out in the respective palace tirazhane and later nakkaşhane by figures such as: Babba Nakkaş, Bihzad, Shahkullu Baghdadi and Kara Memi. This institution seems to have initially developed with the designers who were employed to supply the designs and text woven in the early state Dar al-tiraz, tirazhane of the Omayyad and Abbasid Caliphates (Serjeant, 1972, in particular, 727, 203 and 262-3) and to supply the designs for the coinage struck at the state mints, and who would have been closely connected to the Caliph and the Companions, as later to the ruler, chancellery and high state officials, as this work involved the public official expression of legitimacy and of the titles, formula and name of the ruler and therefore required the correct design and use of the appropriate words, forms, motifs and patterns.

The nakkaşhane under a variety of names, from the time of the early Caliphs was one of institutions associated with ruler ship, and both the designs and the institution of the central nakkaşhane in Baghdad, seat of the Abbasid Caliphate, were, as time passed, copied by regional rulers (For an outline of the importance of this institution for pattern and design and the circulation of these patterns and designs, see for example, Duggan, 2006, 165-74), together with the institution of the tirazhane (For the origin, location and function of tirazhane, see, Serjeant, 1972, in particular, 7-27; also for the Fatimid tiraz treasury of the banners employing a staff of 3,000, Bierman, 1998, 121), where the clothing often issued twice a year, in spring and autumn, which was worn by the official class, was woven in a variety of qualities of cloth, with its characteristic tiraz bands of inscription and decoration on the upper sleeves recording the name and titles of the ruler and Caliph, and thereby visually marking an official as an official, and in the quality of textile employed marking the officials' rank, and, proclaiming in script and design the name of the state's ruler and the ruler's legitimizing affiliation (Fig. 2). The tirazhane was also where the kiswa, the annual coverings for the kaaba with its woven inscriptions, and where the khil'a, the robes of honour often embroidered and always carrying inscriptions, were made, 
which were given as gifts to some important guests, high state officials and envoys; and it was the place where palace carpets, many carrying inscriptions in Arabic and Persian from the earliest times, including prayer rugs carrying inscriptions (For references to Persian and Arabic texts woven in carpets before the $14^{\text {th }}$ c., see, Serjeant, 1972, in particular, 9, carpets from the reign of al-Mustansir with inscriptions in Persian; 51, at the time of Harun al-Rashid with an inscription reading, 'What Hammad 'Adjrad ordered to be made'; 75, for carpets with inscribed with poetry from Tabaristan at the time of the Caliph al-Mu'tasim; 97, for the weaving of carpets in the tirazhane in Merv; 155, for every carpet produced at the tirazhane at Bahnasa, Egypt, to carry the name of the tirazhane on it, and that of the recipient; 203, for prayer carpets, musalla, and other carpets with inscriptions, recorded at the time of Harun al-Rashid; 68, for the forbidding in Tabriz in 1293 of making of inscriptions on gold brocade textile except at the ruler's court, that is, in the palace tirazhane, Tabriz; and also the possibility of a carpet type that was so covered in script, that it was recorded as, 'read', that is 'maktu' carpets, from Akhmim in Egypt, 156, fn. 171, citing Ya'kubi), were woven. In the Rum Seljuk Sultanate there was a tirazhane (The silk tiraz with paired lions and recording the name Alaed-Din Keykubat I, found in an abbey in the Auvergne, that is today in the Lyon, Musee Historique des Tissus, 23.465, France, was almost certainly woven in the Rum Seljuk tirazhane located in Konya, the place where much tiraz were woven, and it seems probable that the carpets provided for the mosques founded by Rum Seljuk as other sultans also came from the palace tirazhane, as it is evident given the original considerable size of some of the Seljuk carpets, $2.58 \times 5.50$, that they were woven in a factory, as also for example, Serjeant, 1972, in particular, 155, "for every carpet produced at the tirazhane at Bahnasa, Egypt, to carry the name of the tirazhane on it, and that of the recipient" and, 97, recording the weaving of carpets in the tirazhane in Merv. It seems probable that the fine $13^{\text {th }}$ c. carpets recorded from Aksaray by Ibn Said, d. 1274, were initially from, or were associated with another tirazhane at the Aksaray palace, working to designs supplied by the palace designers, as later for example, the designs of Mamluke and Uşak carpets, as also the design of the Ardabil carpets, which are clearly the work of palace designers) and nakkaşhane were established at Konya, Sivas and Malatya, probably following the nakkaşhane precedent established by the Abbasids that had been copied by the Great Seljuks and the adjacent Artukids; while Ottoman nakkaşhane existed at Bursa, Edirne, at the Topkapı Palace (For official record of the international membership of a palace nakkaşhane see for example, Atıl, 1987, 289-297), at Amasya and Manisa. Likewise the majority of Beylik states had nakkaşhane, at Bursa for the Ottoman Beylik and at Adana for the Ramazanoğlu Beylik.

In terms of generating Islamic design, the nakkass - the designers, were and remain the interpreters between the Spirit and the viewer by finding the appropriate modes of expression for this remembrance. The particular design was then spread through its application to a range of different materials and was, in its turn, applied in varied and various ways within differing social contexts: from the workshops in or supplying the palaces and those buildings and furnishings related to the ruler and family, to the viziers, lords and notables, to the town and village craftsmen, to being copied by the nomadic weaver. Record survives of cartoons of designs for carpets being sent in the $16^{\text {th }}$ c. from Istanbul to Egypt for weaving in Egypt (Cartoons of floral design carpets, including tulips and hyacinth, rather than the geometric designs of Mamluke carpets. For the use of cartoons made by calligraphers c. 1000 for building inscriptions, see for example Schimmel, 1984, 25; for example of Arabic text sent to Byzantine weavers to weave into a Fatimid tiraz in the $11^{\text {th }}$ c., see Bierman, 1998, 97); as of designs, including calligraphy, sent from the Topkapı nakkaşhane to be executed by the painters at the İznik potteries; while the transport of palace production, such as the lustre ceramic tiles sent from Bagdad to Kairouan for the mihrab of the Grand Mosque in the $8^{\text {th }}$ c. etc. and the movement, forced or otherwise of designers and skilled craftsmen also served to spread the 
design repertory as well as techniques and created variety within an overall unity of approach.

The impact of theologians of the spirit upon the nakkass and the design output from the nakkaşhane should not be underemphasized. Muhyil-Din ibn 'Arabi, between 1205 and 1221 visited Konya, Sivas and Malatya, he was in Konya 1204-5 and 1210, Sivas in 1216 and Malatya in 1216-18 and again in 1221 (Addas, 1993, 296-310), cities where Rum Seljuk nakkaşhane were situated and, as Semra Ögel has suggested, he had a profound impact upon Rum Seljuk geometric design. (Ögel, 1994, 100-106; 2002, 327). Ibn Arabi records in his work Al-Futuhat al-Makkiyya (Meccan Revelations), how he met a Byzantine painter in Konya, the main capital of the Sultanate, in 1210, and he describes how:

"We proved and assisted his art in respect of a proper artistic imagination, which he lacked” (Austin, 1971, 40-1).

A proper artistic imagination concerns the "what" that is to be expressed by means of art - not the "how", the method or skill, but the meaning that is to be expressed through the means of art and craft. It is noteworthy in this respect that ibn 'Arabi also in his Al-Futuhat al-Makkiya records of the Third Celestial Sphere of the Imaginal World that:

"This is the Celestial Sphere of complete form giving and harmonious arrangement. From this sphere is derived assistance for poets. From it also arrive arrangements, proper fashionings (proper making) and geometrical forms within corporeal bodies... From this sphere is known the meaning of proper fashioning, correct making, the beauty whose existence comprises wisdom, and the beauty that is desired by and is agreeable to a specific constitution" (Chittick, 1994, 81, citing ibn 'Arabi’s, Al-Futuhat al-Makkiya -Meccan Revelations, Vol. II, 275.13).

For further on the imaginal world, entirely distinct from, and different in kind from any imaginary world, see, Burckhardt, 1989. For the earlier statement made in regard to calligraphy, "In general, as it has been said, handwriting is spiritual geometry by means of a corporeal instrument", see, Abu Hayyan at Tawhidi's c. 926 to after 1010-11, work entitled, A treaties on penmanship, translated in Rosenthal, 1971, 27, where references in Arabic sources to Euclid as the original source for this remark are cited in the notes, and Plato and Galen are also attributed as sources for it, eg. Irwin, 2005, 124, although it may be a reference to the importance of due and proper proportion and its celestial origin, rather than to any direct citation from antiquity in reference to script and the spiritual origin of abstract proportion - the music of the spheres, in what survives of the work of Euclid, although possibly the citation was from some now lost part of his On Divisions of Figures - peri diaipeseon biblion, book on divisions of figures, although there is no mention of this phrase in the restoration based on Woepcke's text by A. C. Clare of 1915. It is also mentioned in a fragment attributed to Ahmad b. al-Tayyib al-Sarakhsî d. 899, although possibly later, a parody on the importance of geometry or, perhaps, on the reason and revelation argument with the host cast as Hanbalite influenced fool at the Shiite Buyid court: "Euclid (he continued) was the author of a book which contains many different figures leading to the knowledge of how things, both known and hidden, really are. This books (sic) sharpens the mind, refines understanding, and gives thorough knowledge. It clears the sensory perception and establishes intellectual insight. Handwriting was developed from it, and the qualities of the letters of the alphabet were recognized ", Allen, 2004, accessed 09.10.2012. Islamic Art and the Argument from Academic Geometry Occidental, Calif. Solipsist Press, no page numbers, electronic press, in the chapter entitled: Neo-Platonism and Geometry in Baghdad: an Anecdote. However, it is evident that ibn Arabi's cosmography, including the third celestial sphere, is considerably different from the theory of the harmony or music of the spheres of Plato and 
Pythagoras and their later commentators-followers).

It was of this knowledge, "the meaning of proper fashioning, correct making, the beauty whose existence comprises wisdom, and the beauty that is desired by and is agreeable to a specific constitution", that ibn 'Arabi imparted to the Byzantine painter in Konya mentioned above, knowledge of that which is to be made by means of art. The emphasis upon the geometry within forms, of proper fashioning and design in this passage, and the relationship of beauty to a specific constitution, are important, not only for the appreciation of Seljuk art but also because it clearly indicates the importance of this metaphysical contribution towards our understanding of the fashioning, the making of Islamic design and pattern.

Likewise Mevlana Jelal ad-Din Rumi and later Mevlevi dervishes provide us with a clear example of this link between the spiritual discipline and its expression in design, calligraphy, poetry and music. Many, perhaps all nakkaş - designers were members of a spiritual tarikat, together with the vast majority of the master craftsmen responsible for executing and so circulating these designs in a variety of media. This is so, because the burden of creating a design which leads both outwards and inwards to the ocean of God is an immense task. To articulate the diversity within the unity of the Truth, so far as is humanly possible within the constraints of human intelligibility and measure, is no simple accomplishment, or is perhaps very simple indeed; while a repetitive task, the application of the design to an object or material can be crowned with both meaning and therefore value to both the maker and to the user through the application of meaningful designs clothing the functional material form.

The employment of the same designs over a variety of different materials and in different social contexts formed a significant element in providing the Islamic community with a degree of unity and with a shared visual vocabulary of meaningful embellishment, enabling certain patterns of thought, and providing roads through the morass of matter for the alert mind looking for the signs of God. The use of this particular repertory of designs, enabling easy identification of a work as a work of Islamic art, related the community - in buildings, in everyday objects of attire and use - to the religion, Islam, by providing a tapestry of unified and meaningful symbolic designs which both distinguished the community and clarified and exhibited the intellectual domain of Islam, gracing matter with significance provided through the application of these design. Although, of course, a supporting element to the vocalized word of God in speech and prayer, and to script-calligraphy, these designs formed the visual framework within which the traditional Islamic community lived and which they chose to inhabit, a climate of signs, reminders and indications and which, over the course of lifetimes has had an incalculable impact upon minds looking for the certainty of Truth and for reminders of that higher meaning within the man-made environment, and of reaching towards the Truth aided in part through these reminders which were deliberately embedded into the designs and patterns covering the man-made things that surrounded a person every day - the eyes being the windows to the soul.

It is perhaps surprising that in an age of mass production, when the realization of a cultural climate through meaningful design employed on a wide scale and over a range of items is both easier and cheaper to do, given recent manufacturing and technological developments, than at any other time in human history, that with remarkably few exceptions, such as the Turkish KAV matchbox designs of the 1980's (Fig. 3), design-branding is tied to product image and to company identity, to the exclusion of the wider and deeper meaning and of the importance of pattern and design within the community and of its service, of benefit to both the individual and to the society as a whole. Is there, for example any particularly important reason for the exterior of a refrigerator to be white, rather than to carry a meaningful design? Why has meaningful design on the surfaces of the objects forming our man-made environment today been largely discarded, surfaces reduced to the level of carrying no meaningful pattern, often just a company 
name and a trade-mark logo? On a scale of relative values where does one place the remembrance of the Almighty and where the name or logo of the modern national or international corporation, and are these value reflected on the surface of the merchandise, as on the packaging, on the multitude of surfaces that surround and are consciously and indirectly seen by us in the course of our everyday lives?

\section{The Tulip and Crescent Moon, the Rose, Stars and Numbers}

One example of this deep well of meaning beneath the surface, hidden in the folds of Islamic pattern and design is provided by the tulip. This flower may have been first deployed in some of the designs of the carved stuccowork of $9^{\text {th }}$ century Abbasid buildings at Samarra in Iraq. It then appears on the Friday mosque at Kazvin in 1113 and from this point onwards the tulip is frequently to be found in mosques as elsewhere and forms a distinctive element of Islamic design, particularly but certainly not exclusively from the $15^{\text {th }}$ to the $19^{\text {th }}$ century within the Ottoman Sultanate. Another is the crescent moon, which from the early Abbasid period, if not before, was employed as a motif in Islamic works of art (For example it is recorded one of Harun al-Rashid's girls, "wore a crescent on the front of her dress with verses inscribed on it,", Serjeant, 1972, 203).

\section{Why?}

Hisab-i Cumel (abjad-ebced)(For the EBCED systems, see, Yakıt, 1992; Mercanligil, 1960. For the use of this system in the $13^{\text {th }}$ c. see for example the section in Muhammed b. Ali b. Süleyman er-Ravendi’s Rahat-üs-Sudur ve Ayet-üs Sürur, II cilt. “Galip ve Mağlup” Hakkında, 411-420, 1999) is the term used to describe the numerical equivalents of the individual letters comprising the alphabets of Arabic, Persian and Ottoman script, which are alphanumeric scripts. Number, mathematics and geometry are of course vital to Islamic design, as to architecture and engineering in its various forms, and an alphanumeric script enables the relationship between meaning, and the word-Word, and the pattern or design representing that word and meaning(s) that it supports, not necessarily synonymous, to be brought close together (For examples of a word written in Arabic script carrying a different meaning when its numerical equivalents are noted or are added together, see below). The "ebjed" - ebced system of letters employed to represent numbers was used for example to record the verse counts of early copies of the Koran (See for example, Blair, 1998, 221) and this relationship between letter or word and a number forms a fundamental part of the mindset of those educated in an alphanumeric language where letters also signify numbers and numbers are letters, and it is perhaps noteworthy that the Prophets of monotheism came from those peoples employing alphanumeric script, Hebrew, Aramaic and Arabic.

The letters that comprise the word Allah, when their numerical equivalents are added together, give a total of 66. Two other significant words carry this same numerical equivalent of 66 - Hilal meaning crescent moon (Crescent moons also form a design motif on a brass ewer from Syria dated 1232, probably used for ritual washing, Atıl 1975, Cat. No 26. Jelalad-Din Rumi describes the Prophets as moons, Mathnavi, 1982, book 5, 3542, that is casting a reflected light in the night of this temporal world, as the Prophet had described his Companions as stars, in a hadith, that is guides, in the night of this temporal world) and Lale meaning Tulip. In consequence of this numerical correspondence the form of the crescent moon and of the tulip were and are used as the visual symbols indicating and reminding of the Almighty (Figs. 4-7).

The crescent moon has been employed in the Islamic world as the alem (finial) of minarets, of domes, of mimbers in mosques, at the apex of mihrabs, as the finial of flag poles and on standards, woven in textiles, carved in stone and wood, and struck on coins for centuries. One can "read" the carvings of the crescent moon: as for example carved in the apex of some of the 
Fatimid stucco panels inside the al-Azhar Mosque, Cairo after 970; carved in stone crowning the mihrab frame surround in the Divriği, Kale Camii of 1080-1, (Barkırer, 2000, Res. 33) on the apex of the mihrab donated by al-Afdal to the mosque of ibn Tulun in Cairo before 1094, (Barkırer, 2000, Res. 18 from Creswell) the pair carved above the door on the wooden mimber of the Alaed-Din Mosque in Ankara of 1197-8, repeatedly on the exterior of the mosquehospital complex at Divriği of 1228-9, those on the lower ends of the stone carved frame and also at the foot of the palm on the relief to either side of the entrance to the Çifte Minareli Medrese at Erzurum of 1253, those carved in stone on the portal of the Inci Minareli Medrese in Konya by 1258, those on the Döner Kümbet in Kayseri of 1276, and forming the main repeat design in the decorative borders above and below the inscription band on the 1210 Eyyubid minaret at Silvan, simply as crescent moon shapes, but to the educated, given the location of these symbols, they were designed to be read as symbolizing and reminding of Allah. A crescent moon formed the finial, the "alem" of the standard sent by the Caliphs to Abbasid recognized rulers upon their accession (Bosworth 1977, 99, for the "hilal-i rayat" sent to the Ghaznavid Bahram Shah together with a black banner with a lion device and the black "chatr" or parasol. Many flags of Muslim territories carried the crescent moon in the $14^{\text {th }} \mathrm{c}$. as is clearly recorded on contemporary Latin portulan charts of the Mediterranean, as on later Ottoman $14^{\text {th }}$ c. and later flags, for numerous surviving examples see, Karatepe, 2008). Likewise the repeat design that fills the fields of several carpets from the Şarkışla Büyük Camii, dating from the late $16^{\text {th }}$ to the $19^{\text {th }}$ c., today in the Sivas Museum (Kayıpmaz, \& Kayıpmaz, 369-374, 489-493, 1999), perhaps unsurprisingly as they seem to have been woven as prayer carpets, represent the crescent moon alem (Kayımaz, \& Kayıpmaz, 1999, 372) at each apex of a repeat zig-zag pattern (For some of the religious and state associations of the zig-zag/joined chevron design see, Duggan, 149-219, 2006, see for example İstanbul, TSM Ktp. H.1221, of 1594, f. 97b, 123a and 223 for illustrations of the "kiswah" of this type in black and dark blue; Ibn Jubayr in his pilgrimage of 1184 records red bands on the green "kiswah" sent by the Caliph al-Nasir li-Din Allah, but it is unclear if these red bands were chevron-zig-zag bands, with perhaps the Abbasid "kiswah" providing the precedent for the use of this design in explicitly religious contexts. This design also employed horizontally on the woven silk tomb cover of Sultan Süleyman (1520-66) and also the design in red and black covering the coffin of İbrahim Pasha d.1536, depicted in the Hünername, İstanbul TSM Ktp. H.1524; this design in red and white also covered the coffin of Valide Sultan Nur Banu, depicted in the 1597 Şahinşahname, İstanbul, TSM. Ktp.Bağdat 200; on the coffin cover of Sultan Süleyman in green and black, bordered by the same pattern in red and orange, Tarih-i Sultan Süleyman, f. 115v., and forms the zig-zag-chevron pattern in inlaid ivory and black wood that covers the dome of a superb $16^{\text {th }}$ c. Ottoman Koran box, İstanbul, TIEM 5. It later forms pattern of the domed upper section of the tent of Sultan Ahmet III, depicted by Levni in his "Surname-i Vehbi" of 1720, f. 41v., 42r. It is possible that this design was employed on a dome in the haram at Mekka, Medina or Jerusalem, there is an indication of this design on the dome of the qubbat al-maqdis in the haram at Jerusalem, Aksoy, \& Milstein, 2000, fig 1, 4, p. 113, perhaps leading to its subsequent use on the interior of some Seljuk domes in Anatolia eg, in the Sirçalı Masjid Konya of 1242 and the Küçük Aya Sofya Masjid, Akşehir of 1278, as also the design on the exterior of some Mamluke domes in Cairo eg. Faraj b. Barquq, as also on the minaret of al-Nasir Muhammad's mosque on the Cairo Citadel of 1335, and on this Koran box and other Ottoman domes. It also occurs in tile-work on what appears to be a depiction of a mausoleum in a walled city in a Timurid Herat mss. of the Shahname, c 1444, Royal Asiatic Soc. London, Ms. 239, f.278r. It also occurs as a border design on the $10^{\text {th }}$ c. silk saddlecloth known as the "shroud of St. Josse", woven before 961 for the Samanid Emir of Khurasan, Abu Mansur Bakhtikin. This zig-zag pattern but vertical rather than horizontal, is depicted in a woven textile worn by a camel riding drummer in a miniature in 
the mid- $13^{\text {th }}$ c. Konya copy of "Varka and Gülshah", T. S. M. Ktp. H.841, s. 36 a; it also occurs vertically in blue and white on banners carried by Islamic forces in some Christian miniatures depicting the Crusades, as later in the first half of the $14^{\text {th }} \mathrm{c}$. on a miniature, İstanbul TSM. Hazine 52b-53a, where the banners carried by both armies carry this vertical zig-zag device. It is also on a triangular shield held by a mounted hunter fighting a spotted feline on an early $13^{\text {th }}$ c. dish from Rusafa?, Syria, Hillenbrand 1999, fig. 6.29, on another triangular shield on a glazed ceramic bowl from Raqqa, Syria, Hillenbrand 1999, fig. 7.38; and was depicted on a $10^{\text {th }} \mathrm{c}$. bowl from Nishapur, where the mounted huntsman armed with a sword and falcon, is dressed in a garment decorated with this design that may represent armor, Metropolitan Museum, New York, Rice 1975, fig. 43. It is also depicted vertically, alternating in red and white, on a brick or possibly a painted brick design, on a building having red doors, and red, black and yellow merlons, in an İlkhanid Shahname of 1331, İstanbul, TSM H.1479, s. 185a), the repeat zig-zag pattern like that which at times was woven in the kiswah that covered the Ka'ba in Mecca as on other textiles of evident religious importance. Although the crescent moon representing the Almighty as depicted for example on the copper dirhams struck by the Zangid ruler Nasir al-Din Muhammed in Mosul (1219-34) as in 1229-30, where a crowned seated ruler figure holds in front of him the crescent moon device (Falk, 1985, Fig. 529), is today sometimes mistaken for being only an astrological device representing a phase of the moon's orbit, it was rather, it seems, at that time of Latin Crusade, designed and minted to emphasise and publicise Nasir alDin Muhammed's commitment to Allah, to Islam and to the jihad, followed by his ancestor Nur ad-Din who had captured Edessa-Urfa from the Crusaders in 1144, rather than the crescent moon struck on these dirhams having primarily astrological connotations (For suggested astrological associations, see for example, Cayci, 85-6, fn. 77). It is for this reason, sense or meaning that crescent moons are placed where they are, in places such as mosque, medrese, standard finial, flag, coin and tomb, where this symbolic reminder is entirely appropriate (Fig. 8, 9).

Once the symbolism and power at the heart of these metaphors is understood, it can come as no surprise to find Du Fresne-Canaye recording in the $17^{\text {th }}$ century:

"One can scarcely imagine how fond the Turks are of flowers, how they always hold them in their hands or (tuck them) into the folds of their turbans, treating them almost as a sacred thing”.

This was simply because for example, roses, like tulips, were "like sacred things", being respectively symbols representing the Prophet and of the Almighty. As Kazasker Mustafa İzzet Efendi (1801-76) wrote, "To read beautiful calligraphy is like smelling the aroma of a tulip" (Derman, 1998, Exh. Cat. 44).

And, simply because tulips have almost no noticeable smell, one may realise that the reference being made is not to the flower itself, but to what the flower represents as a symbol, that is to the Almighty, to the words, that is the scent of the Almighty, issuing from the tulip, which are given to us recorded in beautiful script in the Holy Koran and ahadith. Therefore, when one walks into İstanbul's Rüstem Paşa mosque and sees the crescent moon at the apex of the mosque, on the alem (finial) of the minaret and surmounting the dome, and sees the many tulips on the tile-work inside, one may realize that the whole mosque from floor to finial is proclaiming, in a clearly visible, legible, symbolic language, the Name of God. Likewise the stylized rose-rosette design on the tile-work that covers not only parts of the mihrab-kıble wall of this mosque, but also covers some of the interior walls of the Topkapi Palace rooms that house the Emanat-1 Mukaddese, the sacred relics, may remind, through the known associations made with the rose and the Prophet, (Süleyman Çelibi d. 1422, in his Mevlûd-i Nebi of 1409 records, "Whenever the Prophet perspired, each drop became a rose, each drop as it fell became a treasure", which can be understood as marking through the rose device at the end of 
each ten verses of the Holy Koran, the arrival of the Word and its impact upon the Prophet. While the Hapsburg Ambassador to Kanuni Sultan Süleyman from 1555-60, Ogier de Busbeq, records in his First Letter dated $1^{\text {st }}$ September 1555, "They never allow rose leaves to lie on the ground; for they believe that the rose sprang from the sweat of Mahomet, just as the ancients thought it came from the blood of Venus". Busbeq, 2001, 19; in the 1927 version of the text it further records: "They never allow rose petals to lie upon the ground, for they believe the rose sprang from the sweat of (the Prophet) Muhammed"; and, "they picked up fallen rose petals because, superstitiously, they believed that such petals were the tears of Muhammad the Prophet”; Busbecq, 1927, 243; 252;. See also in respect to sweat and roses and the Prophet's example, as reflected through Sheik 'Abd al-Qaadir Jilani, 1078-1166, also known as, al-Baaz al-Ashhab -The Gray Falcon and, Sultaan al-Awliyaa' -"The Sultan of the Saints", and the founder of the Kardiri Order -Qadiri tariqah whose symbol is the rose: who was sent to $10^{\text {th }} \mathrm{c}$. Baghdad and, "On his arrival there, he received from the Sheik a cup filled with water, the meaning of which was that the city of Bagdad was full of holy people (transparent), and that it contained no place for him. This occurred during the winter season, and no flowers were in bloom. The Shaik, Abd-ul-Qadir-Gilani, put a rose in the cup, signifying that Bagdad would afford a place for him. Seeing this, all present exclaimed, 'The Sheik is our rose', and going to meet him they conducted him to the city, and showed him marked respect. This is the real origin of the rose of the Qadiris... and it is to his connection with the Prophet that we must ascribe his power to produce, miraculously, a rose... The rose of the Sheik is therefore a sign of the Prophet himself, like in the proverb, 'The son is the secret of his father". Brown, 1968, 100-102) of the Prophet (Fig. 10); while the symbol termed a rose-gül marks the end of each group of 10 ayet-verses of the Holy Koran. These 'roses' mark the tears shed by the Prophet, when reciting the Ayet of the Koran, which were gathered as a treasure, mentioned by Süleyman Çelibi d. 1422, in his Mevlûd-i Nebi, the rose marking this grouping of every 10 verses of the Holy Koran. Each group of ten verses marked by the rose = tear of the Prophet Muhammed, could be read therefore as closing with, yâ Muhammed, as the 10 of the 10 verses is yâ $\mathbf{~ a n d ~ w i t h ~ t h e ~}$ rose-gül representing the Prophet, (which is written kâf + lâm $=20+30=50=$ the letter nun $=\dot{\text { ) }}$. But these letters kâf + lâm, meaning rose, are also the first letters of the first two lines of the 37 Ayet of the 39 Sura, Al-Zumar: "Is God not all-sufficient for His servant? Yet they threaten you with those they serve besides Him. Truly, he whom God confounds has none to guide him. But he whom God guides none can lead astray. Is not God mighty and capable of revenge?”, and so, each group of ten verses followed by the rose-gül can also be marked mentally with a, "yâ Allah". The symbolic rose at the center of each hexagonal tile on some of the walls of the Emanat-1 Mukaddese, has 8 outer, 8 inner and a central petal, giving a total of 17, and 17 has a number of meanings, in addition to the sum of the numbers, $1+7=8$, and some of the meanings that can be associated with the number 8 are given below, while 17 can also be "read" as a reminder, signifying the 17 Raka's of obligatory prayer each day, as also the number of times the Takbir, "Allahu Akber", is given during a prayer of 3 prostrations. Consequently the roserosette motif repeatedly employed in Islamic art serves as a visual reminder of the Prophet while the number of petals-segments indicated on the rose-rosette indicates a range of meanings associated with the significance within this religious-cultural climate of a particular number. So when one sees the miniature depicting Sultan Mehmet Fatih smelling a rose one may realise that the reference being made is not just to the flower itself, but to what the flower represents as a symbol, that is to the Prophet and to the words, that is the scent of the Almighty, issuing from the Prophet signified by the rose.

Furthermore, the tulip has six petals, and in the conversion of numbers to letters, Hisab-i Cumel (abjad-ebjed), (See for example the $13^{\text {th }}$ c. account provided by ibn Arabi in chapters of his El-Futuhatu'l-Mekkiyye 1., 2. and 26, ibn Arabi, 2000, concerning the Arabic letters and 
meaning) the number six represents the letter wav, meaning 'and', and, the letter wav meaning 'and', has been regarded since the $12^{\text {th }}$ c., if not before, by figures such as Najm ad-Din Kubra (1145-1220) as being, "the letter of connection between man and God" (Schimmel, 1984, 100), linking the Muslim with the Almighty, with the 'wav/and', explicitly or implicitly meaning 'and Allah'; while the number 6 is also the sum of the letters 132, 132 being the number produced through adding the numerical equivalent of the letters comprising the name, "Muhammed" (Likewise the word Yasin, of the Holy Koran Sura, Yasin, provides the number 134 and, 134 is also the numerical equivalent of the name Samed -Samet صמمد, which is one of the Names of the Almighty, meaning the Eternal, the Most High. Thus the word, Yasin is, in this sense, the equivalent of Samed). Further and noteworthy is the fact that there are 114 Sura/chapters in the Holy Koran, and $1+1+4=6=$ the letter wav, meaning, and (Allah). A representation of a tulip showing the six petals can therefore be "read" as representing both lale and 6=wav, "and Allah, and Allah", and also "read" as representing, wav, and (Allah) and the whole Koran; while for example the 3, 5, and 7 physical leaflets on some rose bushes, $3+5+7=15=1+5=6$ (Fig. 1 ) can likewise be "read" within this religious-cultural perspective as wav, and thereby reminding of Allah, of Muhammed and of the whole Koran (In this respect it is worth remembering that traditionally there are said to be 6,666 words in the Holy Koran; and this can be represented by the letter wav repeated 4 times, that is mirrored on both a vertical and a horizontal axis).

Given what the number 6 can be understood to represent within this particular religiouscultural climate to the educated, and the importance attached to remembrance, is it therefore in anyway surprising that six-sided shapes, hexagons, were frequently employed in tile-work, in woodwork, as in architecture, with hexagonal columns, as at the Sinan Paşa Mosque in Besiktaş, İstanbul; or as the shape employed for the drum supporting a dome, as at the Umayyad Dome of the Chain in the Haram ash Sharif (Noble Sanctuary) in Jerusalem, or the Üç Şerefeli Mosque, Edirne, which also has two hexagonal piers; or for the design of a minaret, such as the hexagonal minaret of al-Ruha (Urfa) after 1146, of the 1568 Murad Paşa Mosque in Damascus, or of both the Al-Mehdi and also the minaret of the Akbariyeh Mosque in Lahijan in Gilan; as also for the plan of a tomb, such as the tomb of the Caliph al-Muntasir in Samarra, Qubba alSulaybiya of 862, the plan of the tomb of Osman Gazi and of the Yeşil Türbe (Green Tomb) in Bursa after 1421. Six pointed stars are frequently encountered in Islamic design, such as the 6 pointed star of cut tile work in the apex of the dome of the 1224 Ulu Camii, Malatya, with each arm of the two triangles forming the star, composed of cut-tile work carrying the word Muhammed in Kufi script read counter-clockwise (Fig. 11). The reason why the name Muhammed is repeated 6 times on the 6 sides of this 6 pointed star may be related to the same reason that the name Ali was at times repeated three times inside a hexagon (see below) in this same period, that is, the repetition itself may indicate to the educated a change from an alphabetical to a numerical "reading". Consequently this design can be "read" as a total of 6 from the 6 points of the star indicating the six directions $+6+6+6+6+6+6=42=4+2=6$, "reading" with the dome with its turquoise tile-work understood as the representing the universe, in sum total, the universe and with the letter wav, reading as, and (Allah) = the totality of the Almighty and the Universe, while also reminding of the Prophet Muhammed; or the "star" can be "read" as indicating the six directions and as 6, giving a reminder of the Holy Koran and the number of Sura in it, $114=1+1+4+6$ repeated 7 times; or the 6 points of the star can remind of the 6 directions and together with the sum of numbers represented by the letters of the word Muhammed on each arm of the star "reading" 6, meaning a total of 7 wav letters, reminding the viewer of, and (Allah), and of the 6 of the 6 attributes of Allah, Al Sifat Al-Dhatiyyah: that He is the Existing One (Al-Wujud), that He is the Pre-Eternal One (Al-Qidam), that He is the Everlasting One (Al-Baqah), that He is the Unique One (Al-Wahdaniyyah), that He is Unlike the created (Al-Mukhalafatun lil khawadith) and, that He alone is the Self-Existing One (Al- 
Qiyam bi'naf's uhi). It is perhaps noteworthy that the sum of the numerical equivalents of the 6 mim letters within the centre hexagon formed at the centre of the two triangles $=240=$ $2+4+0=6$. Other six pointed stars were composed of tile-work consisting of a hexagonal tile surrounded by 6 triangular tiles, with examples in the Muradiye Mosque, Edirne, as also in the turbe of Murad II at Bursa and in the Çinili Köşk and on the exterior of the Sünnet Odası, Topkapı Palace, İstanbul, with the 6 points to the star provided by the triangles, when added to the 6 sides of the hexagon, means this type of 6 pointed star can be "read" as 6 points plus 6 sides, and so can be "read" as $6+6,66$, and in consequence, like the mirrored wav, the lale-tulip and hilal-the crescent moon, remind of the numerical equivalent of the letters forming the word Allah.

The letter wav (Fig. 12) with the numerical equivalent of six was frequently doubled in calligraphy (Fig. 13, 14, 15) as also in calligraphic sculpture, as in the Ahmet III library in the Topkapı Palace which has, suspended from the ceiling, a gilded sculpture of the doubled wav, (Fig. 16) which can be read as sixty six (Schimmel, 1984, 101), and which therefore, like the tulip and the crescent moon, symbolizes and so reminds of Allah. This doubled wav was and remains a typical motif employed in the Kayseri Yahyalı seccade carpets that were woven from the $19^{\text {th }}$ c. onwards, where the doubled wav letter in white or yellow was placed at, or towards the top, of the doubled mihrab and in the field above it, contrasting with the representation of settlement confined to the border of the seccade (For examples see, Resim 1-6 in, Çağlıütüncügil, 1999. It seems probable that some Karaman Taşkale seccade carpets carry in the repeat tulip borders to the mihrap, the tulip flanked by a leaf on either side with the leaf terminating in a wav, see for examples, Resim 13, 15, and the drawing by Soysald, 181. Barışta, 43-48, 1999. This would indicate a combination of alphanumeric-symbolic readings, with 1. The wav+Tulip-Lale reading, "and Allah"; 2. The two leaves terminating in wav letters meaning a doubled wav reading as $6+6$ and so the numerical equivalent of the word Allah 66; 3 . While the tulip also represents the numerical equivalent of the word Allah); while some Central Asian silk Ikat carry the letter wav (Fig. 17); and some embroidered seccade made in Keçimushine Köy, Konya, in the $19^{\text {th }}$ and $20^{\text {th }}$ century, if not earlier, carry nine hundred and ninety nine copies of the letter wav, the repetition of the letter-word, 'and', forming almost the entire field of the carpet, each individual letter stitched in coloured thread, and in some examples, some of the coloured wav are stitched of a different coloured thread so that a large single, or a doubled wav is also visible in the design, while others, in addition to the wav covered field, also carry the word Allah in mirrored Kufi script six times, and also its resemblance, approximations to, and so visual reminders of this word, in the word, written eight times in square kufi below the word Allah, that can be read as, sanat, meaning the example of the Prophet, the Sunna, as also the word, year (See for it employed in this form on the coinage, to mean the mint date, Bernardi, 2007, 7), (Fig. 18).

Likewise the design employing groups of three circular motifs, each motif composed of one, two or three crescent moons which each enclose a full moon, that can be seen on objects from tile-work (Figs. 19, 20), other ceramics and carpets, to the kaftans of Sultans, which carry this motif which is today called chintamani (See for example, Birol, \& Derman, 2001, 169-170), have it seems in fact nothing to do with tiger skins, tiger stripes, "a combination of stripes and three dots" (Hillenbrand, 2005, 279), nor Chinese motifs, except for a passing meaningless resemblance, but instead repeat the Name of God in implicit symbolism. The three crescent moons, the three hilal, of the usual Ottoman "chintamani motif", as also on some Ottoman military flags (see Fig. 9), represent Allah repeated three times, 3 times in the crescent moons of the whole group forming the design. The number three carries a series of particular meanings (see the list given below, in addition to being the sum of $66,6+6=12=1+2=3$ ) while, in 
addition, if one troubles to add 66 together 3 times, once for each time Allah is represented by this crescent moon symbol, one arrives at a total of 198 . The number 198 carries a number of meanings, the 99 Names of God repeated twice, and also signifies as a number, the name of the Prophet Yakub-Jacob, the Prophet who was of the faith of Abraham, neither Jew nor Christian (Holy Koran Sura Al-Baqarah, 2: 135-7). Likewise, when this design is depicted, as sometimes it is, as a group of four crescent moons (Fig. 21), one can read this design in this way, that when 66 , the numerical equivalent of hilal, the crescent moon, is added together four times, one obtains the number 264, and, one of the words that is used in the Holy Koran which has letters, the numerical equivalents of which add up to 264, is, مدكر (To find the word(s) employed in the Holy Koran which are equivalent to a particular ebjed number, see for example: www.kurananaliz.com/ebcedgoster.asp This is certainly not to imply that this is all there is to the Word, as some Hurufi and others have maintained, but that the numbers provided through the use of the alphanumeric script employed, Arabic, can serve also a reminder of the Creator and of Faith and this common knowledge was deliberately employed by at least some of the designers responsible for Islamic design) meaning, remember-remembereth, and which is used repeatedly in the $54^{\text {th }}$ Sura of the Holy Koran, Sura Al-Qamar (The Chapter of the Moon), employed within the context of remembering the Koran, "We have made the Koran easy to remember: but will any take heed?". Consequently, to those who have been educated within the relevant cultural-religious context, that is furnished with the appropriate learning, this design speaks, not of any chintimani, nor of any Chinese influence, nor of any tiger skins, but of the need within this temporal world to remember the Almighty, Sura Al-'Ankabut, 29:46, "Nothing is greater than the remembrance of God", and to remind those who have been educated to remember, to pay heed to the words that are recorded in the Holy Koran.

It may be that the so called "tiger stripes", which are often to be found in groups of three beside the three crescent moon motifs of this design are to be read as representing Sirat, the narrow bridge over the fire leading to paradise, hence the usual red on either side of a thin white line, or perhaps, al-Barzakh, that is representing the isthmus, between the different orders of reality, the barrier between the salt water and the fresh, the two seas, or perhaps signifying the path taken by Islam (Holy Koran, Al-Fatihah, "Guide us to the straight path, the path of those whom You have favoured, not of those who have incurred Your wrath, nor of those who have gone astray"), neither Jewish nor Christian, although the Path, like Sirat, is usually described as being narrow or straight.

In the same fashion, the 40 different depictions of tulips to be found in the Fatih Mosque in İstanbul have a symbolic significance, each tulip standing, in the eyes of those of a contemplative educated disposition, as a reminder of God, and also, when the total of 40 different tulips is realized, of the various 40's mentioned in the Koran and in Islamic symbolism: The $30+10$, that is the 40 nights of Moses waiting before receiving the tablets of the law (Koran, Sura Al-Ar'af 7:142); the 40 years wandering of the Jews (Koran Sura Al-Ma'idah 5:26); the 40 years of age when the Prophets İdris, Hud, Salih and Muhammed began their vocations as Prophets; the 40 years for a man to reach completion (Mathnavi, Book 3, verse 3502); the 40 days to create Adam (Mathnavi, Book 6, verse 1216); and the 40 chapters of al-Ghazzali's Ihya'ulum ad-Din The Revivification of the Religious Sciences; and with forty often employed to mean many, rather than precisely forty, which give further pause for reflection and contemplation, of the reflection of the many aspects of the One in both the natural and within that manmade environment which has been ennobled by significant and meaningful design (Figs. 22).

The symbolism to be found in the writings of Najm ad-Din Daya Razi (died 1256) and of Nasir ad-Din of Konya, a contemporary of Jelal ad-Din Rumi (1207-73), given the cultural 
coherence and integrity of Islam, also provide us with indications as to how to interpret some contemporary Rum Seljuk designs. Both scholars wrote educational works, widely taught and read in the Seljuk Sultanate. Daya Razi's Mirsad al'ibad (Watchtower for Devotees), is divided into 5 sections formed by the 40 chapters of the book, and the author states clearly that these 5 sections represent the five pillars of Islam and that the 40 chapters that the book contains represent Musa's (Moses's) forty days communion with God and also the Prophet's recommendation that the seeker worship devoutly for forty days (Renard 1996, 211). Najm adDin also emphasizes 3, the tripartite nature of human life, from our origin, to the life in this world, to return to our Creator. Similarly Nasir ad-Din in his Tabsirat al-Mubtadi (Clarification for beginners and reminders for the advanced) uses a threefold division in his "Three Lamps": firstly, knowledge of the Creator, secondly, spiritual friendship and prophecy, and thirdly, the two worlds - this place and the world to come. This same three-fold division is to be found in his Mutali-i imam (The rising places of faith) to describe the three principles of belief: firstly, faith in God, secondly, faith in Prophecy and thirdly, faith in The Last Days (Renard 1996, 201).

This mode of thinking in terms of symbols and letters represented by numbers having a particular religious significance seems to find its visual expression in the order of geometric repetition and in the numbers of component elements within an Islamic design. Is it any wonder that certain numbers that define a particular motif or shape in a design occur so frequently, as for example, on the tile-work of the walls of a teaching institution such as a medrese? The shapes of the tiles themselves, as well as the designs upon them, can be understood to serve as a visual reminder and an enunciation of these same reminders of the principles of knowledge. Thus when one sees on the hexagonal tile-work of the Karatay Medrese of 1251, a design of 3 elements joined together on a tile, there is the implicit suggestion, given the intellectual framework of the period, the place and its function, that the informed observer would at times recollect not only the meanings attached to the 6 of the hexagonal tile; but of the various 3's spoken of in the Koran, mentioned by Najm ad-Din, Nasir ad-Din and by others: the 3 fold darkness of the womb (Koran Sura Sad, 39:6), the 3's of words, sounds and breath, and of giver, thing, receiver; to the 3 days silence of Zacharias (Koran Sura Maryam, 19:10), and "By that which is dual and that which is single" (Koran Sura Al-Fajr, 89:1) which provides a totality of 3, the 3's of Allah, Muhammed and Ali, and of, Imam, Islam and Ihsan, of Faith, Submission and Virtue, to the 3 forms of prayer - dhikr, salat and du'a (Fig. 23).

Likewise the use of 7 motifs forming the design on many hexagonal tiles, one in each corner and one in the centre, for example those of the Muradiye complex at Edirne of 1436, which may have been produced to line the walls of a medrese or a Mevlevihane and which were then reused in this mosque (Goodwin, 1992, 62, 73), as likewise the 7 motifs surrounding the mihrab on some embroidered susani (Figs. 24, 25) are reminders, implicit reminders, of the various 7's: of the seven Ayet of the First Fatiha-Hamd Sura explicitly mentioned in the Holy Koran, Sura AlHijr, 15:88, the 7 circumambulations of the Ka'ba, the 7 Heavens, the 7 Sleepers, the 7 Universal Faculties, the 7 Hells, to the 7 fold meanings of the Holy Koran (Mathnavi, Book 3, verse 1897) (for further examples, see the list given below).

There are numerous references to stars in the Koran and undoubtedly this resulted in the design and the use of the star patterns employed on many works of Islamic art, including on the portals of many $13^{\text {th }}$ c. Rum Seljuk, on Ayyubid, and other buildings, on carved mimbers, in manuscript illumination and bindings, on carpets and textiles, as on other works. For example, Sura 53 is entitled An-Najm, النج, The Star, Ayet 1: "By the star when it setteth" and this Sura also mentions the 7 Heavens, the star Sirius, and contains the account of the Night Journey made by the Prophet of Islam from Mecca to Jerusalem, to Paradise and the region of the Throne of the Almighty; while Sura 85 is entitled, Al-Buruj, The Mansions of the Stars and 
begins: "By the heavens, holding mansions of the stars and by the Promised Day.", while Sura 86 is entitled, At-Tariq, The Morning Star and begins: "By the heavens and the morning star. Ah, what will tell thee what the morning star is! The piercing star!". In addition, there is the hadith, reporting the words spoken by the Prophet of Islam: "My companions are stars; whomsoever anyone of you follow, you will be rightly guided". The numerical equivalent of the letters of the word, النج , The Star, are 124 and the sum of this number, 1+2+4=7 and the number seven has numerous associations (see the list below), including reminding of the $7 \mathrm{oft}$ remembered verses of the Fatiha, and of the 7 Heavens. Thus there are a complex of references, of both alphanumeric and Koranic meanings, deliberately employed by the designer that can be associated by the educated viewer with a work of Islamic art that includes a star or stars with for example, 5, 6, 8, 12 or more points, or which is covered by a star pattern, and both the presence of a star in a design and also the number of its points, conveyed a number of associations and reminders to the educated (Figs. 3, 11, 23, 24).

Once the significance of the abstract and symbolic use of number is realized within the context of the application of Islamic spiritual geometry, then the geometry embedded in much Islamic design can be understood as acting as a reminder, and it clearly served and still serves this particular spiritual function - it is not just decoration as a method employed of filling a given space (In this respect carrying a similar meaning to the later remark by St. Bernard of Clairvaux, c.1090-1153, concerning Cistercian architecture, "There must be no decoration, only proportion". It should be noted that Cistercian buildings carried decoration, but not decoration empty of meaning, and decoration in due proportion), and is far from that meaningless activity, as it carries implicit meanings, signs, and these can be read by those aware, as educated and in possession of this knowledge, as signs reminding of, and pointing towards the Truth. These designs are not ends in themselves, nor were they intended to be complete of themselves, but instead, it seems evident, were made to serve only as reminders towards that Truth. It may perhaps be hard today to enter into this traditional Islamic intellectual mind-set, of the informed intellect and of the heart, where repetition creates further resonances and where people formulated verbal, physical, mental, numerical, geometrical, mathematical and visual methods to ensure that they were reminded in their everyday of Allah the Almighty; but to discard the superb spiritual and intellectual accomplishments of generations of Islamic designers as being "just decoration", filling up an otherwise empty space, or as designs that are complete and entire of themselves, unrelated to the intent and the significance of these associations, is to misunderstand the reason and function of these designs, as though the designers of Islamic art for the past 1400 years have created designs because their patrons just wanted something to fill up an empty space, suffering from a 'horror vacui', as has been frequently stated by Western orientalists and which is frequently repeated today (Horror vacui, fear of the empty space, and the related Cenophobia fear of the empty, has been repeatedly employed by Western art historians in the attempt to explain away the initially overwhelming impact of Islamic design, as though filling an area with a repeat pattern carried no meaning beyond the desire not to see a bare wall or blank page or plain textile. See for examples of this strange assertion, Schimmel, 1984, 9, "The horror vacui, which is considered a formative principle in so much of Islamic decoration, seems to have contributed to the invention of these forms that, in the course of time, developed into the innumerable varieties of floriated and foliated Kufi, to which the plaited was very soon added", that is, that the so-called horror vacui caused calligraphers from Afghanistan to Egypt and Andalusia to develop these styles of calligraphy, and, if this is not sufficiently odd, as a way of explaining such a change, it's worth recalling the scholar Richard Ettinghausen and his, "The Horror vacui in Islamic Art", reprinted in, Rosen-Ayalon, 1984, 1309, who explains the so-called horror vacui of Islamic art in part through reference to the crowded nature of New Eastern cities, the empty spaces between them, and, "the tendency in the Islamic world toward 
exaggeration and lavishness, not outwardly in the streets, but in personal relations". I think these are both unfortunate and inaccurate remarks. Firstly, because the largely pejorative adjectives, 'exaggeration and lavishness' are not tendencies unique to human relations in the Islamic world and, it could be argued, have been and are regarded in the Islamic world as excesses which are known to be frowned upon by the Almighty, eg. Sura Al-Isra, 17:27, "Do not squander your substance wastefully, for the wasteful are Satan's brothers"; likewise, AnNisa 4:29. Secondly, because undecorated surfaces such as white or single coloured cloth were, and are, highly regarded, and because it is often the plain areas, "the vacui" in the design, that are employed to intensify the impact of the decorated areas. Thirdly because meaningful decoration is neither necessarily exaggeration nor necessarily lavish, the fact that gold and silver have been employed to carry the same pattern as that painted elsewhere in cheap pigment on a wall or stamped in leather, is rather a matter of wealth and context. Fourthly, because crowded cities and empty spaces between them are also characteristic of places outside the Islamic world, but these places do not necessarily chose to employ this same use of pattern, although presumably suffering likewise from this same so-called, and I think entirely imaginary, horror vacui. Interpretations, doubtless based in some part on western European unfamiliarity with arid landscapes, and as though to compensate for inhabiting this landscape Islamic designers covered surfaces with patterns. A somewhat shallow, temporal, orientalist orientated response to the intellectual domain and product of the educated intellects of Islamic state institutions such as were employed at courts and in the tirazhane and nakkaşhane in the Islamic world for centuries to produce meaningful designs and patterns), at a time when individual personal taste, corporate advertising and fashion have been elevated above spiritual meaning in the embellishment of surfaces, and which is to be understood perhaps rather as a sad reflection upon our own times and upon our own lack of seriousness and of awareness in this matter. The works themselves still speak today, it is however often the case that it is we who have forgotten how to look, how to listen, how and what to remember and what to attend to, with the loss of contemplation and concentration, of our attention span, and so have often forgotten that very thing of which we need to be reminded of in the present and for our own spiritual health and future.

Some idea of the range of associations that can be made between the repetition of a single motif a certain number of times on an object, or the number of times a different pattern or a different colour is employed on an object, or for a shape, employed in a pattern or as tiles, defined by its number of corners, $3=$ =triangle, $4=$ square $5=$ pentagon $6=$ hexagon, $8=$ =ctagon etc., is indicated in the list given below, giving of some of the well-known meaningful reminders and just some of the associations that would have been made, and which can be made today, within this Islamic context for the numbers from one to ten, that can lead to reflection and recollection of our human situation.

1)

- The unique, The One - Allah - God (Koran, Sura Al-Ikhlas, 112: Al-‘Ankabut, 29:46).

- The one religion (Koran, Sura Al-Mu'minun, 23:52).

- The formerly one community of mankind (Koran, Sura Al-Baqarah, 2:213).

- By that which is single (Koran, Sura Al-Fajr, 89:1) the singular, such as the alif, the one-like form, like the lance thrust in the ground as a marker for the direction of prayer (harba-harb-mihrab) used from 624 onward to point the direction of prayer and depicted on the coinage, such as the silver dirhams minted in c. 692-4 under Abd alMalik depicting the lance within a mihrab niche (See also, Treadwell, 2005; Miles, 1952, 156-71); and the Prophet's staff placed upright within the mihrab, as later indicated for example by the vertical strip of ornament in the marble mihrab niche from the Khassaki Mosque of $8^{\text {th }}$ c. Iraq; (Brend, 1991, Fig. 10) or, as in the alif/one-like form 
of the minaret, serving as visual reminder of the One and the visual marker of the place for public prayer to the One.

- The number 1 is represented by the Arabic letter, Alif.

2)

- Pairs (Koran, Sura Ya' Sin, 36:36) "Glory be to Him who made all things in pairs", as in night and day, male and female.

- The two seas (Koran, Sura Al-Furqan, 25:53, Al-Fatir, 35:12, Al-Rahman, 55:19).

- Angels with 2 or 3 or 4 pairs of wings (Koran, Sura Al-Fatir, 35:1).

- The pairs of recording Angels, that record the deeds of a person (Koran, Sura Al-Qaf, 50: 17-18) Munkir and Nakir.

- $\quad$ The 2 worlds (Divan Shemsi Tabriz IV).

- By that which is dual (Koran, Sura Al-Fajr, 89:1) meaning that which is not the Almighty

- The two gardens (Koran, Sura Al-Rahman, 55:49).

- The two Easts and the two Wests (Koran, Sura Al-Rahman, 55:17).

- The unknown and the manifest (Koran, Sura Al-Mu'minun, 23:93).

- The two, those of the Right and those of the Left (Koran, Sura Al-Hadid, 57:12).

- The double share of His mercy, a light to walk in and forgiveness (Koran, Sura AlHadid, 57:28).

- The mosque of the two Qiblas, the Kaba and Jerusalem, the Quba Mosque in Medina.

- The number 2 is represented by the Arabic letter, bâ.

3)

- The three parts to the bismilla = "Allah", "al-Rahman", "al-Rahim" (It may be worth noting that the ritual ablution entails saying the bismilla, and then the washing of: the 2 hands, mouth, both nostrils, face, both ears, both forearms, head and both feet, $2+1+2+1+2+2+1+2=13$ each three times $=13+13+13=39,3+9=12$ and the sum of $1+2$ giving 3 ).

- The 3 forms of the soul or nafs (Koran, Sura Yusuf, 12:53, Al-Qiyamah, 75:2, Al-Fajr, 89:27).

- The three of, those of the right, those of the left, and the foremost (Koran, Sura AlWaq'ia 8:10, 8:41).

- $\quad$ The 3 of Words, Sounds, Breath

of Nature, Action, Speech

of Sounds, Words, Talk

of Giver, Thing, Receiver.

- The 3 days to contemplate a transaction (Mathnavi, Book 3, 3496).

- The 3 days silence of purification of Zacharias (Koran, Sura Maryam, 19:10).

- The 3 fold darkness of the womb (Koran Sura Al-Zumar, 39:6).

- The total of 3 in: "By that which is dual and that which is single" (Koran, Sura Al-Fajr, 89:1).

- Angels with 2 or 3 or 4 pairs of wings (Koran, Sura Al-Fatir, 35:1).

- The three times washing in ablution before prayer.

- The number 3 is represented by the Arabic letter, jim.

4)

- The 4 Archangels.

- The 4 Books: Torah, Psalms, Gospels and Koran. 
- The 4 Rivers of Paradise of the Koran, of honey, milk, water and wine.

- The 4 Gardens of Paradise (Koran, Sura Al-Rahman, 55:46, Al-Rahman, 55:65).

- The 4 Angels supporting the Throne of God.

- The 4 Sacred Months of the year (Koran, Sura Al-Tawbah, 9:36) Muharram, the first month in the calendar, Rajab, the seventh month, Dhu'l Qa'da, the eleventh month and Dhu'l Hajja, the twelfth month.

- The four stages to the pilgrimage, $8^{\text {th }}-10^{\text {th }}$ Dhu'l-Hijja: The Departure for Arafat, The Standing on Arafat, The Day of Sacrifice and, The Journey to Mina.

- The four places where faith abides: in the heart, in the head, in the tongue, and in the members. The strength of the heart consists in joy, the strength of the head in knowledge of the truth, the strength of the tongue in sincerity, and the strength of the members in submission. Recorded in the Tale of Sympathy the Learned, in, Mardrus, \& Mathers, 1996, 154.

- Of the Lord of the two Easts and the Lord of the two Wests, Allah (Koran Sura AlRahman, 55:17).

- The 4 corners of the earth.

- The 4 main schools of law or Madhhab.

- The 4 wives legal to a Moslem who can support them equally.

- The 4 witnesses needed to testify in any case of adultery.

- Angels with 2 or 3 or 4 pairs of wings (Koran, Sura Al-Fatir, 35:1).

- $\quad$ The 4 friends, the first 4 Caliphs (Mathnavi, Book 6, verse 1895).

- $\quad$ The 4 birds (Koran, Sura Al-Baqarah, 2:260).

- $\quad$ The 4 natural properties: hot, cold, moist, dry (Mathnavi, Book 6, verse 448).

- The 4 elements (Mathnavi, Book 6, verse 48, Divan Shemsi Tabriz V).

- The number 4 is represented by the Arabic letter, dâl.

5)

- The 5 pillars of Islam, sometimes represented by a hand carved above gateways.

- The 5 canonical prayers per day, Divan Shemsi Tabriz XLIV "The senses are the 5 prayers...”.

- $\quad$ The 5 senses (Mathnavi, Book 4, verse 1811).

- The 5 capacities contained in the Name Al-Basir, The Seer, meaning He who knows: He who knows the Day of Judgement; He who knows the future; He who knows the place of every person's death, He who knows the time of rain; and He who knows the child hidden in the womb of the mother.

- The 5 digits of the, "hand of Fatima". Often worn as a talismanic amulet, as also born on military standards and a reminder of the 5 pillars of Islam.

- The number 5 is represented by the Arabic letter, hâ'.

6)

- Belief in the six: in God, Angels, Books, Messengers, the Resurrection and Fate.

- The 6 days of Creation (Koran, Sura Yunis, 10:3, Hud, 11:7, Al-Sajdah, 32:04 and Mathnavi, Book 3, verse 3500).

- The six most praiseworthy acts of piety: "prayer, alms, fasting, pilgrimage, fighting bad instincts and forbidden things, to take part in a holy war." Recorded in the Tale of Sympathy the Learned, in, Mardrus, \& Mathers, 1996, 148.

- The 6 directions, north, south, east, west, up and down (Mathnavi, Book 6, verse 4, Book 4, verse 1811 and Book 3, verse 3108).

- $\quad$ The 6 dimensions (Divan Shamsi Tabriz XXXIX). 
- The 6 hands of classic calligraphy.

- The number 6 is represented by the Arabic letter, wav, meaning, and (Allah).

7)

- The "7 oft repeated verses" of the Fatiha, (Koran Sura: Al-Hijr, 15:88, Divan Shemsi Tabriz VI \& XLIV, “The senses are the 5 prayers, but the heart is the 7 verses").

- The 7 Heavens (Koran Sura: Al-Mu'minun, 23:17, Al-Talaq, 65:12, Al-Mulk, 67:3, Nuh, 71:14, Al-Naba', 78:15, Divan Shemsi Tabriz II \& XLIV).

- The 7 fold circumambulation of the Ka'ba in Mecca (Tawaf).

- The 7 fold walk of the pilgrim between the hills of al-Safa and al-Marwa on the Haj.

- The 7 pebbles brought to Mina by the pilgrim on the Haj at Mecca.

- The 7 months it took to build the first mosque at Mdina for the community, $56 \mathrm{~m}$. per side.

- $\quad$ The 7 parts to a Rak'a of prayer.

- The 7 blue celestial spheres (Mathnavi, Book 6, verse 108).

- The 7 members of the body: head, chest, belly, two arms, two legs (Mathnavi, Book 6, verse 1799).

- The 7 openings in the head: two eyes, two ears, two nostrils and mouth.

- The 7 planets associated with the 7 heavens: firstly the Moon, Mercury, Venus, the Sun, Mars, Jupiter, and lastly Saturn. Associated by Nizami in his 1198 Haft Paikar (Nizami, XVIII-XIX) with the 7 stages of the spiritual path, Saturn with black and Saturday, the Sun with yellow and Sunday; the Moon with silvery green and Monday; Mars with red and Tuesday; Mercury with blue and Wednesday; Jupiter with sandalwood and Thursday; Venus with white and Friday. The association between particular colours and stages of the spiritual path has been often made but these have varied, for example, black sometimes exchanging places with white as representing Haqiqa-the Truth, like the black flag and also the white flag employed after the hijra.

- $\quad$ The 7 seas (Mathnavi, Book 5, verse 389).

- The 7 candles (Mathnavi, Book 3, verse 1983).

- $\quad$ The 7 fold meanings in the Koran (Mathnavi, Book 3, verse 1897).

- The $7^{\text {th }}$ Islamic month "Rajab", the $27^{\text {th }}$ day of which marks the Prophet of Islam's Night Journey - Laylat al-Mi'raj.

- The 7 canonical ways of reciting the Koran.

- $\quad$ The 7 roofs of Heaven (Mathnavi, Book 4, verse 1842).

- The 7 sleepers (Koran, Sura Al-Kahf, 18:9).

- The 7 earths (Koran, Sura Al-Talaq, 65:12).

- The 7 Suras of the Koran that begin with the two letters, ha mim.

- Muhammed Abu Hamid Ghazali's division of the 24 hours of the day into 7 parts, each part having its own wird or particular devotional exercises (Padwick, 1969, 21).

- The 7 universal faculties: Life, Knowledge, Will, Power, Hearing, Seeing and Speech (faculties possessed in their fullest by the Almighty and to a lesser extent by humanity).

- $\quad$ The 7 gates to Hell (Mathnavi, Koran, Sura Al-Hijr, 15:44).

- $\quad$ The 7 Hells (Mathnavi, Book 6, verse 4607).

- The 7 layers of the earth (Arberry, Fi Ma Fih Ch. 63).

- The 7 metals.

- The 7 colours, haft reng. For a version of the several versions of the 7 colours, see above under 7 planets.

- The number 7 is represented by the Arabic letter, zâ. 
8)

- $\quad$ The 8 Angels that carry the throne (Koran, Sura Al-Haqqah, 69:17).

- $\quad$ The 8 Gates of Paradise.

- The 8 Heavens of Paradise.

- The 8 kinds of livestock (Koran, Sura Al-An'am, 6:143).

- $\quad$ The 8 Paradises (Mathnavi, Book 5, verse 1737).

- The 8 Names to be seen on calligraphic roundels in many Ottoman mosques, of Allah, Muhammed, Abu Bakr, Omar, Osman, Ali, Hassan and Husain.

- The number 8 is represented by the Arabic letter, haâ.

9)

- The 9 Spheres of Heaven (Mathnavi, Book 4, verse 1823, Divan Shems Tabriz XIX, Ibn-i Sina etc.), that is the 7 planets plus $8^{\text {th }}$, the heaven of the signs of the zodiac falak al-Buruj and the $9^{\text {th }}$, the heaven of heaven falak al-aflak.

- The 9 clear signs of Moses (Koran, Sura Al-Isra', 17:101).

- The 9 creatures with wings named in the Koran: "the gnat, the bee, the fly, the hoopoe, the crow, the grasshopper, the ant, the bulbul and the bird of Jesus (upon whom be prayers and peace!), which is none other than the bat". Recorded in the Tale of Sympathy the Learned, in, Mardrus, \& Mathers, 1996, 155.

- The $9^{\text {th }}$ month in the Islamic calendar of fasting, "Ramadan".

- The 9 months of the child in the womb (Mathnavi, Book 6, verse 1215).

- The number 9 is represented by the Arabic letter, tâ.

10)

- The 10 fingers (Mathnavi, Book 6, verse 1658).

- The 10 hearts: "the heart of the believer is a pure and healthy heart, the heart of an Infidel is exactly the opposite; there is a heart attached to things of this world, and a heart attached to spiritual joys; there is a heart mastered by the passions, by hate or avarice; there is a slack heart, a heart burning with love, a heart puffed with pride; there is a lighted heart like that of the companions of our Holy Prophet; and there is the heart of the Prophet himself, which is the heart of the Chosen". Recorded in the Tale of Sympathy the Learned, in, Mardrus, \& Mathers, 1996, 154.

- The ten immaterial results of true prayer: "it lightens the heart, it brightens the face, it pleases the Compassionate, it infuriates the devil, it attracts pity, it repels evil, it preserves from ill, it protects against enemies, it fortifies the wavering spirit, and it brings the slave nearer to his Master". Recorded in the Tale of Sympathy the Learned, in (Mardrus, \& Mathers, 1996, 148-149).

- The 10 senses, being the 5 inner and the 5 outer senses (Mathnavi, Book 4, verse 2022).

- The tenth day of the $12^{\text {th }}$ month, Dhu al-Hijjah, marking the feast of sacrifice.

- The tenth day of the first month, Muharram, marking 'Ashura.

- The number 10 is represented by the Arabic letter, yâ.

Consequently, when one sees a traditional prayer carpet-seccade, carrying a repeat pattern of 3 , 6, 9 (Fig. 26), 11, 33 (Fig. 27) (The words for Sun, Shams, al-abraar khamr, and Light, noor, both appear 33 times in the Holy Koran; which if added together gives 66, reminding of the Light of Allah the Almighty), 66 or of 99 (As for example a Döşemealtı carpet, woven 50 years ago, has a field with 11 rows of 5 motifs, each motif an eight pointed star in a pentagram, alternating with 11 rows of 4 motifs of eight pointed stars, giving a total of 99 eight pointed stars in rows on a plain white field. The 99 Names of God al-asma al-husna are recalled in the prayer beads or tespih carried by many Moslems. These prayer beads can contain: 11, 33 or 99 
beads, and one can still see far longer chains consisting of 99 beads repeated 11 times, 1089 beads and others of 3267 beads -33 times 99 or even -99 times 99, 9801 beads. These longer chains used in rituals of remembrance of God, as are the smaller tespih, repeating the 99 Names of God along with other prayers such as the Shahada which expresses the unity of God and the Tahmid which gives thanks to God for His blessings in whatever form they may take, not only what is usually regarded as good, but for illness and ones' own fate, blessings given by God. People may speak aloud the prayer, as they tell the beads, or the prayer may be silent, as the beads are moved on the string. There is said to be an efficacy in this repetition that not only controls the breathing but helps one to practice concentration against the forces of distraction within the world, and using the tespih can also generate a perspective that puts this temporal world in its place relative to the Absolute) motifs, woven for example in 3 or 7 colours and having a particular number of patterned borders, one can be reminded, in addition to the 99 names of God (For the 99 Names, see for example, Al Ghazali, 1992; Sheikh Tosun Bayrak alJerrahi al- Halveti, 1985) implicitly suggested in the use of these numbers of motifs, sometimes explicitly represented as 9 or 11 beads within the mihrab of a seccade, or of 33, 66 or 99 flowers or other motif repeated within a border, one may be reminded of some of the many meanings associated with the number seven, forty (Fig. 22), sixty six, ninety-nine etc. One is therefore given, beyond the material object itself, something of meaning to contemplate in the colours, the design and the particular motifs and the numbers thereof employed, that can cause in us remembrance, the visual form of "dhikr Allah".

\section{The Lamp}

Likewise, if there is a depiction of a mosque lamp woven in the prayer rug, or forming the design of a work of calligraphy, or is depicted on a painted tile, or is carved in stone in the mihrab of a mosque (As for example carved twice, literally "light upon light", one above the other within the stone mihrab of the late $13^{\text {th }}-14^{\text {th }}$ c. Alevi Sultan Mescid, today in the İnce Minareli Müzesi, Konya, Inv. no. 907, Bakırer, 2000, 207); or a mosque lamp that is made from glazed ceramics (Fig. 28) or of metal, rather than of glass, that is a symbolic mosque lamp (For some examples of these symbolic ceramic mosque lamps, see for example, Atasoy, \& Raby, 1994, Figs. 78; 80; 88-91; 105-109; 157; 158; 283; 288-290; 293-296; 306; 355; 377; 568-574; $713 ; 721 ; 738 ; 768)$, one that serves to remind of a spiritual, not just or only of a temporal light, such as are often depicted within the stepped mihrab niche-Mt. of Mercy-Mt. Arafat (The stepped type of prayer rug, often with stylized lamps on each step, can be clearly related to the depictions of Mt. Arafat, the Mt. of Mercy, recorded in haj certificates dating from the $12^{\text {th }}-13^{\text {th }}$ c. See for examples, Aksoy, \& Milstein, 2000. One typical example from 608 AH, 1211 (Türk İslam Eserleri Müzesi no. 4091), shows a flight of steps up the sides of Mount Arafat, each step lit by candles and with a lamp on top. The steps of Arafat were lit by lamps for the standing at that time. See for example Ibn Jubayr who provides an account of his pilgrimage in 1184 in which a description is given of Mount Arafat (Jabal Arafat or Jabal Rahma - The Mount of Mercy: "The Mount of Mercy... is located in the middle of the plain (of Arafat). It was difficult of access until Jamal al-Din... had gentle steps made on all 4 sides by which it is possible to go up even with loaded animals... At the top is a domed shrine." He goes on to describe the candles: "It was the same on a Friday night for the Mount of Mercy and its Mosque, since the non-Arabs of Khurasan and other pilgrims of the Iraqi caravan are the most moved to bring candles and use them in profusion to illuminate the venerated sanctuaries” Peters, 1994, 125. This contemporary account describes accurately the appearance of Mount Arafat represented on the "stepped" type of prayer rugs lit with candles. These pictures on Haj certificates measure up to $50 \mathrm{~cm}$. across, and seem to have had a clear influence on the design of some prayer rugs and also the "garden" type of carpet with a pool and other structures, in part because they were 
placed on public display in mosques as the proof of pilgrimage. Both the design and the colours employed in these $13^{\text {th }}$ century pictures show a remarkable similarity to the design and colouring of much later surviving "stepped" prayer rugs. Perhaps therefore a more accurate name for this type of prayer rug should be the "Mount of Mercy" or "Mount Arafat" prayer rugs. The departure for Arafat on the $8^{\text {th }}$ Dhu'l-Hajja marking the first of the four stages of the pilgrimage and the standing on Arafat on the $9^{\text {th }}$ Dhu'l Hajja the second, and so, the stepped mihrab on the seccade can recalls to the believer, Jabal al-Rahma-Mt. Arafat, the Prophet's farewell pilgrimage, and the goal of the believer in this pilgrimage through life of reaching The Merciful) on a prayer rug (For example, Bennett, 1977, 197-201), one may come to realise through the repeated use of this depiction in and upon a variety of materials, that a meaning, a sign, a reminder, is being given to the aware, and, through this use of the representation of a lamp one can thereby be reminded of the lamp and of 'His light', of the Divine Light of the Almighty, and so of the Almighty, that is recorded in the Sura Al-Nur, (Chapter Light) 24:35, "God is the light of the heavens and the earth. His light may be compared to a niche that enshrines a lamp, the lamp within a crystal of star-like brilliance. It is lit from a blessed olive tree neither eastern nor western. Its very oil would almost shine forth, though no fire touched it. Light upon light; God guides to His light whom He will”. The image of the lamp itself thereby summoning up the text, serving as a reminder, with the Word being refreshed in the alert mind, brought to mind through this visible visual symbol of the One, be it on the prayer mat, carpet or carved or painted on a wall.

This was and remains the intention of the nakkaş, the human designer, which was, and remains to remind the believer in a subtle, deep and implicit manner of the thread of meaning linking Creator with man, of the need for us to remember, to remember what lies at the end of the letter wav, of each "and" that we utter - that is the Almighty; and this is because we human beings have, it is recorded, almost from the very first, been prone to forget what is truly necessary, what we truly are, as is recorded in the Sura Ta' ha', 20:115, "And We made a covenant with Adam, but he forgot".

Or Sura Al-An'am, 6:44-5, "And when they had clean forgotten Our admonition We granted them all that they desired; but just as they were rejoicing in what they were given, We suddenly smote them and they were plunged into utter despair. Thus were the evil-doers annihilated. Praise be to God, Lord of the Universe".

To combat our human propensity for forgetting, it was understood that we needed manmade visual reminders, both explicit and implicit, large and small, situated throughout our manmade environment, the natural world being clearly marked by the signs both large and small given to it by the Almighty, and it was the provision of these reminders, the clear and the subtle, the explicit and the implicit, within the man-made environment which was, and remains, the task of the designers.

\section{The Four Archangels}

The tiles produced in Adana to designs provided by the Ramazanoğlu Bey's nakkaşhane, form one of the finest displays of ceramic art in Turkey at the Ulu or Ramazanoğlu mosque in Adana (Fig. 29). The mosque was begun by Hilal Bey in 1513 and was completed by Piri Mehmet Bey in 1541. When the Ottoman Sultan Süleyman Kanuni "the Lawgiver" restored the Qubbat asSakhra, the Dome of the Rock in Jerusalem, (Figs. 30, 31) beginning in 1543 (Restoration work continued into the reign of Murad III, Goodwin, 1992, 291, fn. 18. For these tiles see for example, Porter, 1995, 102-4, the tiles were produced on site, some by 1545-6, others by 'Abdallah Tabrizi in 1552, but the origin/first use of this design is not given. This same design was repeated on Syrian $16^{\text {th }}$ and $17^{\text {th }}$ c. tiles and also on Kütahya tiles, often in cobalt blue on 
white, which were produced into the late $19^{\text {th }}$ and early $20^{\text {th }}$ centuries), his craftsmen employed the design which occur earlier in the tile-work of the Ramazanoğlu - Ulu Mosque in Adana and repeatedly in Ottoman Syria, as over the mihrab-kıble wall in the congregational Mosque in Aleppo. Why was it that at this time, when the Ottoman nakkaşhane in the Aslanhane in the first courtyard of the Topkapi Palace was producing superb designs for silk weavers as for the ceramic workshops of İznik and Kütahya, designs that defined the priorities and enveloped, enhanced and enriched the man-made world that the Ottomans inhabited through the surface designs applied to its objects, that this design from the Ramazanoğlu nakkaşhane was chosen to be used to clad and cover the exterior, as part of the important restoration work carried out by order of the Sultan Süleyman Kanuni, at the third holiest place in the Islamic world? This design was then taken into the Ottoman repertory of designs, and tiles were subsequently produced resembling this pattern but in the Ottoman maniera, (Fig. 32) as for example employed on the tile revetments on the interior walls of the Topkapı Saray enderun Library of Ahmet III (Fig. 33).

Having used one of these designs, usually described as "lily and lotus" (El Aref, 1966, 36 "Lily and Lotus Design"), as "floral patterns" (Clevenot, \& Degeorge, 2000, 24), or, as "palmette patterns" (Degeorge, \& Porter, 2002, 212. Described by Anthony-Slayter Ralph Fine Art in their catalogue to the sale of the collection of Lockwood de Forest II (1850-32), Part II, Fig. 5, as, "A stone paste tile decorated in under-glaze blue and black outline with a design of a central palmette encircled by stylised lotus with intertwining tendrils, a pair of floral quadrants at diagonally opposite corners. This tile is similar to others from the Dome of the Rock in Jerusalem that were part of the refurbishment of the mosque in the mid- $16^{\text {th }}$ century ordered by Kanuni Sultan Süleyman between 1545 and 1552. Following the completion of the work, the craftsmen responsible for the Dome of the Rock restoration dispersed and thus the design was probably carried to other Ottoman provinces. This blue and white version can also be found on the adjacent Qubbat al-Silsileh and on the Beit Jamblat in Aleppo. $16^{\text {th }}$ century"), over the past 19 years in my work, after a considerable period of ignorance, followed by some research, I realized that this tile repeat pattern is to be understood as forming a group of 4 tiles, and that this group represents in a stylised form the 4 Archangels of the Koran, each set between and joined to two circles. The circle enclosing a void, formed at the junction of these 4 tiles, which is the

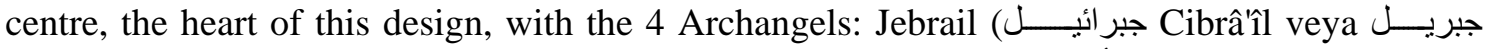
Cibrîl, 236=11=2 conveyer of Revelation to the Prophets), Azrail (قــابض الأرواتحل, Azrail, 239=5 conveyor of souls when the bodies time has come to die and the soul to depart), Mikail (إسرافيل, İsrāfîl, 371=2 conveyor of the sound of the clarion at the end of time), (In this order the initial letters of the four Archangels spelling out the word Al Jami, meaning that which unites and also, the place of the Friday-congregational prayer, and the word Al Jami provides an ebced total of 114, the number of Sura in the Holy Koran, and a number which can be read as, $1+1+4=6$ which is the numerical equivalent of the letter wav, meaning, and "Allah") standing between the "Two Worlds", of this, the realm of the relative, and that other world, that of the Absolute, and with each angel having their beginning and end in the Absolute symbolized by the circles, but with their wings spanning this world of the relative. Further, if one adds the numerical equivalent of the word Gabriel, that is, $236=2+3+6=11=1+1=2$, to Mikail, $91=9+1=1+0=1$, to Israfil, $371=11=1+1=2$, to Azrail, $239=2+3+9=14=1+4=5$, that is, $2+1+2+5=10=1+0$, one reaches the number 1, which can be "read" as the letter Alif, symbolising the One God, the Almighty. It seems clear that it was because of these four archangels and for this meaning, for this sense and reason, that Kanuni Sultan Süleyman's restoration employed this tile design on the exterior resurfacing of the Qubbat as-Sakhra. This pattern was employed in the renovation of this very important building, not because it looked pretty with a floral pattern, nor because to some today it seems to resemble a lily, lotus, palmette or a floral pattern, and this tile design has of course 
little, if anything at all to do with "palmette", "floral patterns", or "lily and lotus", the modern names given to this traditional design, through doubtless having some perceived superficial resemblance to them.

It is rather the case that The Designer can be recognised through the designs, as some are led to recognise the All Mighty through the attention they paid to the signs and wonders of the natural world, and as the designers of traditional meaningful designs placed signs within the man-made environment to be "read" and so to remind of the Almighty, through the forms, colours, letter-numbers or shapes employed, and likewise in the full understanding that the design itself is never to be mistaken for the meaning that it embodies and conveys, but is to be understood simply as another form of reminder, a sign, an indication, as likewise are the Signs provided by the Almighty including the Sign-Ayet of the Holy Koran, as also those recorded as placed by the Almighty within the natural world and within us. To mistake the sign for that which it signifies is ignorant and, within this context, simply idolatry. This point was made by Jelalad-Din Rumi in his Mathnavi:

"...take the (essential) meaning of the story, O imbecile! Not like him who has heard (some) fables, and like the "sh" stuck to the (literal) shape of them. So that he would say,

"How should Kalila, having no language, hear words from Dimna who had no power of expression? And (even) if they knew each others' accents, how should man understand it (their talk), (since it was) without any articulation? How did Dimna become a messenger between the lion and the ox, and cajole them both with his palaver? This "Kalila and Dimna" is entirely fiction, or else how should the stork quarrel with the crow?"

"O brother, the story is like a measure: the real meaning in it resembles grain (in the measure). The man of intelligence will take the grain of meaning: he will not pay any regard to the measure, (even) if it is removed (altogether)" (Mathnavi, Book 2, 3615 ff.).

It was understood in $13^{\text {th }}$ century Konya, as had been the case throughout the Islamic world since these stories had been edited, emended and translated into Arabic by "Abd Allah ibn alMuqaffa (c. 721- c. 759) during the reign of the Caliph al-Mansur, as "Kalilah wa Dimnah" (Hitti, 1991, 308; Browne, 1997, 275; Nicholson, 1998, 346; Irwin, 1999, 76-84), that the pair of jackals, "Kalila" and "Dimna", represented human courtiers to the lion, the lion representing the Sultan-ruler and that the ox symbolized his vizier. That is, beasts represented humans, and, on occasion, particular people were seen in the form of particular beasts, as Jelalad-Din Rumi relates of one of his followers: "I saw him in the form of a wild animal, upon him the skin of a fox" (Arberry, 1961, 144-145, where "him" refers to his spirit and the fox skin refers to his form. It is of importance to note that people in the past lived in far closer proximity to nature, to wild animals and birds and of a greater variety and quantity than obtains today. Both wild and working animals and birds and beasts of prey were a part of peoples every-day and they were understood to possess qualities and characteristics, to act as symbols, the way some people today invest qualities, status and a symbolic value in motor vehicles, cell phones, computers and other trappings of modernity, with the obvious difference that these creatures were alive, living and inhabiting the same space and environment as people, whereas the trappings of modernity are without The Spirit and are not alive), as also in Rumi's story where a Jew, a Moslem and a Christian are represented as birds, a crow, a falcon and an owl respectively (Mathnavi, 1982, Bk 6, $2377 \mathrm{ff}$ ). Thus, verbal, written or pictorial images were expected to have, and were understood by the educated to represent, not only, or just themselves, but also to possess a meaning, or a 
series of meanings, that is to act as reminders to, and are to be seen as symbols of, representing something other than the form itself. As for example letters in an alphanumeric script represent numbers, and for example the numbers of motifs also represent letters, and so the mirrored letter wav can be understood, like the crescent moon and the tulip, to represent the word Allah and, likewise, is not Allah. In consequence the world and the Word to the educated aware believer are certainly not wysiwyg, the computer acronym meaning, what you see is what you get. This place and all the natural things within it, also carry meaning and have value as indications, are Signs to be read, written in time and space and recorded on the tablet of the Almighty, in addition to their material physical form, and so, what you get is rather more than what is at first seen and sometimes a pattern leads a great deal deeper than any initial glance would have lead one to expect. Do you notice a sign, a design, a pattern produced within this religious-cultural climate with just the eye, with the attending informed contemplative or the distracted mind, or with the heart? Remembrance can be initiated, belief can be renewed, refreshed, through the individuals' sudden realisation of meaning, leading one to see through/beyond the physical pattern or design, as at times through the natural world, one of the reasons why although the design is itself explicit, crystal clear, sharp edged, not imprecise or fuzzy, the meaning is not necessarily immediately apparent, and deliberately has often not been made clear and explicit at first glance to the viewer; and these designs also carry a series of numerical values that can also serve as reminders of meaning pointing towards the Truth. These traditional designs were made with seriousness to this purpose. Likewise the script in the meaning that it carries to the literate is both explicit and implicit in terms of the levels of understanding and of the associations that can be made and internalised, and the letters and words employed also carry a numerical value that may also indicate a particular meaning itself, as indicated in the list above, and can also, when added together, can remind at a further level.

Likewise Rumi said: "Know that these words are as the skin (rind), and the meaning is (as) the kernel; these words are as the form, and the meaning is the spirit" (Mathnavi, Book 1, 1097), reminding of the fact that, "God speaks in metaphors to men" (Holy Koran, Sura Al-Nur, 24:35), that meaning is of the Spirit only inhabiting the form that clothes it, and to mistake the temporal form for the Truth, the skin for the meaning, the tulip or the Alif for the Almighty, is idolatry, and missing the point. Also pertinent in this respect are Rumi's words in respect to a seeker after the tree-water-Reality of Life, the Truth:

"Thou hast gone after the form, thou hast gone astray: thou canst not find it because thou hast abandoned the reality.

Sometimes it is named 'tree', sometimes 'sun'; sometimes it is named, 'sea', sometimes 'cloud.'

(It is) that one (thing) from which a hundred thousand effects arise: its least effects are everlasting life.

Although (in essence) it is single, it hath a thousand effects: innumerable names befit (may be properly applied to) that one (thing).

One person may be father in relation to thee; in regard to another individual he may be son.

In regard to another he may be wrath and a foe; in regard to another he may be graciousness and a friend.

(He hath) hundreds of thousands of names, (but) he is one man: the owner of every quality belonging to him is blind to (incapable of) giving any (true) description (of him).

Whoever seeks the mere name, if he is entrusted (with a confidential mission) he is hopeless and in distraction, even as thou art. 
Why dost thou stick to the name 'tree', so that thou art left bitterly disappointed and ill-fortuned?

Pass on from the name and look at the attributes, in order that the attributes may show thee the way to the essence.

The disagreement of mankind is caused by names; peace ensues when they advance to the reality (denoted by the name)".

(See for example, Rumi Mathnavi, 1982, Book. 2, 3670-80, for form versus reality, and name versus knowledge of the named and, Book. 3, 524-30, in regard to the sign and the reality of the imagery).

Likewise the terms classical archaeologists rightly employ, sphinx, siren, griffon, to describe winged beasts, some with human heads, to describe antique representations of these creatures, as these names are attested to in the literary sources contemporary with and issuing from the same religious-cultural climate; when these same terms are applied to objects which were produced within an Islamic context, for example in Fatimid, Ayyubid or Rum Seljuk art, this leads inevitably to confusion and to misunderstanding, as these forms within this $10^{\text {th }}-13^{\text {th }} \mathrm{c}$. religious-cultural context represent something quite different, the jinn, and have no resemblance in terms of meaning, although depicted with a similar form to the sphinx, siren and griffon of antiquity. As also the term "koç buynuzu"- rams horns, (Fig. 34) which is today frequently missapplied to describe the design, amongst others, that clearly representing the reflex bow and target, sometimes even with the siper, the attachment for flight shooting depicted (Fig. 35), as the bow was an object having great symbolic importance in Islamic culture and art unlike rams horns, with the symbol of the bow and arrow implicitly raising the matter of who truly fires the arrow at the target, "And thou didst not throw when thou threwest, but God threw" (Holy Koran, Al-Anfal 8:17, "It was not you, but God who slew them"; paraphrased by Rumi in the Mathnavi Book. V, 1. 2241, "If we let fly an arrow, that action is not from us, we are only the bow, and the shooter of the arrow is God") and, when combined with the target, was designed to remind not just of the physical practise of archery, but of its wider meaning, as to what the target of this life is, and of how to reach it, a reminder of whose assistance is needed, of whose will prevails, of whose aim is true, of the return to the Creator, etc. an important image repeatedly employed within this religious-cultural context, to direct the attention towards the target, towards the goal, the Beginning and the End, the Return. As paraphrased by the late $13^{\text {th }}$ c. teacher Nasred-Din Nasrudin on the matter of whose will is effective and how to reach the target- Whose shot was that?:

"The fair was in full swing, and Nasrudin's senior disciple asked whether he and his fellow students might be allowed to visit it.

'Certainly' said Nasrudin, for this is an ideal opportunity to continue practical teaching,' The Mulla headed straight for the shooting gallery, one of the great attractions, for large prizes were offered for even one bulls-eye. At the appearance of the Mulla and his flock, the townsfolk gathered around. When Nasrudin himself took up the bow and three arrows, tension mounted. Here, surely, it would be demonstrated that Nasrudin sometimes overreached himself...

"Study me attentively." The Mulla flexed the bow, tilted his cap to the back of his head like a soldier, took careful aim and fired. The arrow went very wide of the mark.

There was a roar of derision from the crowd, and Nasrudin's pupils stirred uneasily, muttering to one another. The Mulla turned and faced them all. "Silence! This was a demonstration of how the soldier shoots. He is often wide of the mark. That's why he loses wars. At the moment I 
fired, I identified myself with a soldier, firing at the enemy."

He picked up a second arrow, slipped it into the bow and tweaked the string. The arrow fell short, halfway to the target. There was dead silence.

"Now" said the Mulla to the company, "you have seen the shot of a man who was too eager to shoot, yet who, having failed at his first shot, was too nervous to concentrate. The arrow fell short."

Even the stall holder was fascinated by these explanations. The Mulla nonchalantly looked towards the target, aimed and let his arrow fly. It hit the very centre of the bulls-eye.

Very deliberately he surveyed the prizes and picked the one he liked the best, and started to walk away. A clamour broke out.

"Silence," said Nasrudin. "Let one of you ask me what you all seem to want to know." For a moment nobody spoke. Then a yokel shuffled forward. "We want to know which of you fired the third shot."

"That? Oh, that was me" (Shah, 1976, 31-32).

Why three arrows (for some of the associations to be made with the number 3 see those given in the list above) and in terms of archery, the first shot was to test the strength of the bow, the second was fired as an abrish-a practice arrow, to test the correct posture and position of the hands, and the third arrow, fired with intent and purpose, was fired by the Real, by "He who is", and this teaching story therefore presents in a concise form the threefold path: ignorance of means, practice and awareness of means, arrival at the target. As the hadith relates, "Learn the casting of arrows and do not be averse to it, for the area between the two targets holds a garden of the gardens of paradise." The Ottoman guild of archers trained the archer to repeat, when releasing an arrow, "What Allah wills happens. There is no god but Allah. There is no power except from Allah." and, at the competitions which were held regularly at the archery field, the Ok Meydanı in Istanbul into the $19^{\text {th }}$ c., the archers of the guild were divided into 4 groups, the first group loosing 12 arrows over the least distance, the second group loosed 9 arrows, the third group loosed 7 arrows and the last group, the master archers loosed 5 arrows over a distance of 820 yards. The total number of arrows released by one archer from each group was 33, and as each arrow was released the three part prayer was uttered, giving a total of 99 prayers; while it was taught that the elders loosed 5 arrows because tradition related that the Archangel Gabriel gave Adam two arrows from God after the expulsion from Paradise, and upon both of these were inscribed the names of five of the Prophets: Noah, Abraham, Moses, Jesus and Muhammed (Klopsteg, 1987, 116).

Sometimes with the loss over time of meaning, of sense and of the associations attached to designs within this particular cultural and spiritual context, one may think that some modern names given to designs, motifs and patterns, trivialize or obscure work that carries a meaning of some considerable religious importance. It is quite odd for example to find a kilim design clearly reminding of the word 'Allah', and another that seems to depict the letter 'alif joined to a wav letter' in kufi script, described as "Şarköy Kilimlerinde izlenen imler", as, 'marks recorded on Şarköy Kilims' (Durul, 1987, 55; as also on a page of Tirşin Yaylası Kilim motifs, the word 'Allah' as forming a part of a 'Batan güneş-Doğan güneş', a rising and setting sun motif, 95; as a "Köpek", a dog, Fig. 6, 40; and its resemblance but with an added Alif, like sunna-sanat in kufi, as a motif described as a "Tarla kuşu", a field bird, Fig 5, 39. As likewise a repeat design reminding of the word Allah mirrored in kufi script on a Medieval glazed mould-made ceramic bowl from Samsat, is recorded as depicting plant motifs, Bulut, 1994, Res. 15, Sek. 9, 10), (Fig. 36). Elsewhere, the reminder of the word 'Allah', unfortunately described as belonging to the bird type motif: "Kuş. Bird. A motif which is loaded with various meanings, ranging from good 
luck to bad luck; happiness, joy and love; the soul of the dead; women; longing; an expectation of news; power and strength" (Kilim Catalogue No: 1 prepared by Güran Erbek, Selçuk A.S., İstanbul, 1990, un-numbered page in the initial section entitled, 'Motifs', within the examples given of the bird type), as some superficial resemblance between the form of the word 'Allah' and a bird, apparently formed the basis for the modern name given to this type of kilim design (Fig. 37), although the representation of the word Allah written in Kufi script in the form of a bird has had quite a long history (Fig. 38).

Likewise, the motif today frequently described by the meaningless modern misnomer, hands on hips-elibelinde, is clearly derived at times from the word Allah in mirrored Kufi script, with the initial alifs joined together (Fig. 39, 40), at others from the word 'Muhammed' written in Kufi script, with the doubled mim letter indicated by the dot within the square mim (Or possibly a mirrored finial square kufi wav, forming the subject of a forthcoming paper), while the socalled pitrak-burdock motif contains the mirrored word Allah (Kilim Catalogue No:1 prepared by Güran Erbek, Selçuk A.S., İstanbul, 1990, un-numbered page in the initial section entitled, 'Motifs', within the examples given of the pitrak motif), (Fig. 40a).

It is quite certain that the descriptions of the $14^{\text {th }}$ century "Marby Carpet", found in the Marby Church, Jamtland, Sweden, that was woven and exported from Anatolia, and which carries the name of God, “Allah”, repeated 4 times, paired in mirror kufi script, within each of the two white ground inner fields of this carpet, above and below words stylized as birds (Fig. 41), is most ill described by calling the word Allah, woven four times in mirror Kufi script in each inner field, "a tree of life", as is the case today with the description of this carpet in many books on carpets (For example, described as, "Vögel auf einem Lebensbaum," in, Öney, G. Bauschmuck und Kleinkunst, 176-214 in, 1980, 210; "Two birds flanking a tree”, in Aslanapa, 1988, 42), or as, "two stylized red birds on an ivory ground flank a central tree whose foliage is reflected in mirror image at the bottom, replacing the roots" (Mackie, 1980, 307), the word Allah repeated 4 times in each inner field described as the central tree and its reflection; and with this design being referred to as belonging to the so-called, "animal carpets" (As for example, Aslanapa, 1988, in his chapter entitled, "Animal figured carpets", likewise, 1994, 384), so as to entirely conceal the Name of the Almighty which is clearly recorded on it. Yet, the initial Alif letter is only bent back so as to join its mirror image (Bent kufi vertical letters are not uncommon, see for example, Bierman, 1998, Fig. 24) and the word is clearly and immediately legible. The 'birds' forming the central motif on this carpet seem likewise to be based upon a word or an expression in a highly stylized ornithomorphic variant of Kufi script (The Herati master calligrapher Majnun, Schimmel, 1984, 32, fn. 107, is credited with the invention of a script of human and animal figures, although they occur much earlier on metalware, such as the Brobinsky bucket of 1163 from Herat and a pen-case probably from Merv of 1210, see, Grohmann, 1955-56, 117-22, and it may be that designs derived from examples of this script, the work of literate palace designers, migrated west into Anatolia and may have been the source of some of these script motifs and of the calligraphic devices on the so-called "animal" figured carpets). As the word Allah is mirrored, in muthanna, aynali script, and the suggested dating of the carpet is the $14^{\text {th }}$ c., the date for the origin of muthanna script should be probably be placed considerably earlier than the $15^{\text {th }}$ c. (The $15^{\text {th }}$ c. date stated by Schimmel, Adler's Foreign Books, June 1970, 11, not in the 1984 edition).

Likewise the borders of the Seljuk period carpets, found at Konya in the Alaed-din Mosque, and at Beyşehir in the Eşrefoğlu Mosque, have been frequently described as carrying "Pseudo Kufi" designs (For example in, Mackie, 1980, 304, and likewise in the works of Oktay Aslanapa; Blair, 1998, 179), but, in fact, several of these carpets have clearly legible Kufi inscriptions repeated as the border motif, including the legible word Allah at the tip of the 
horned Alif (See for example, M. E. Andersen, Thread: The Kufi border and the pelikan at: http://www.turkotek.com/misc_00113/tekke.htm) and reminders of it (Fig. 42), facing in both directions and so reminding of, Al-Baqarah Sura 2: 115, that: "To God belongs the East and the West, whichever way you turn, there is the face of God. God is omnipresent and all knowing" and Al-Baqarah 2:143, "Say, 'The East and the West are God's. He guides whom He will to a straight path". The carpet No 689, today on display in the museum of Turkish Islamic Arts in İstanbul carries a Kufi inscription which reads $L i S a$, the commonly used abbreviation of $L a$ Sahibihi, meaning "Blessings to the owner" (Fig. 43). Both Li Sa and La Sahibihi, written in Kufi script occur frequently on surviving Islamic ceramics from the $9^{\text {th }}$ through to the $13^{\text {th }}$ centuries, particularly in the area from Afghanistan to Iraq and Anatolia ruled by the Seljuks and the epigraphist Chahryar Adle has identified the use of this expression on ceramics produced in Anatolia at Diyarbakr in the $12^{\text {th }}$ century (It also occurs on later ceramics, see for example from the $14^{\text {th }}$ c. the tin-enamelled earthenware brasero in the Met Museum of Art, The Cloisters Collection, 1956 (56.171.162, where it is also described as: 'pseudo-kufic script). Another carpet fragment, which is thought to belong to the same Anatolian weaving tradition was found at Fustat, the pre Fatimid capital of Egypt used in the $13^{\text {th }}$ century as a waste disposal ground for the new city of Cairo, and this fragment is today in the National Museum in Stockholm, Sweden, Inventory Number 43/1936, and this too carries the kufi border motif of $\mathrm{Li} \mathrm{Sa}$, "Blessings to the owner", and this legible script employed as a design means something, it is an Arabic expression, it is not "pseudo Kufi", nor yet a "Kufic motif", as it has been frequently described as in the standard works, but was repeatedly employed, to remind of "Blessings to the owner", an expression which is usually interpreted as calling for blessings upon the temporal owner, but which, rather more correctly in respect to a carpet found, and perhaps originally made for the Sultan's own mosque, in the case of the Konya examples, refers to the absolute owner, that is, calling for blessings upon the Almighty, as in the Divine Name, malik ul-mulk, مَالِكُ مالك expression "Blessings to/on the owner" found recorded upon a very wide range of objects was formerly understood as being a form like the 'bismillah'. The prevalence of legible script on carpets into the $14^{\text {th }}$ c. has been noted above (see, Serjeant, 1972, 9, 51, 75, 97, 155, 156 fn. 171, 203), and remains the case today, for example on some Hakkari herke which carry the approximation of the word Allah in blue (Like the blue glazed tile kufi inscriptions of Allah, Muhammed and Ali over the exterior of the tomb of Zayn al-Mirza c. 1473, HisnkayfaHasankeyf), and upon some Yomuk kufi-taj-skull caps, words such as "Muhammed", "Ali" and "Allah" in Kufi script 'crowning' the head.

Likewise it seems that individual letters, as well as particular words and of designs resembling and so reminding of these words, were deliberately woven into carpets and kilims, to serve as signs and reminders, such as what is today often termed the çengel-hook motif (The matter of some superficial visual association, as between the letter khaf, ha and jim in kufi and a hook, the word Allah mirrored and the branches of a tree, of a reflex bow to rams horns; or of there being a visual resemblance between designs produced within different cultural contexts being indiscriminately associated together by art historians, as in the sun-swastika motif from 4000 B.C., as a repeat pattern employed on some Roman stone cornices, as employed as a joining design in kufi repeat inscriptions, and as a state symbol in 1933-45 Nazi Germany, is both meaningless and nonsensical. This is because the same design carries a different meaning within a different religious-cultural context. The meaning to be expressed comes prior to the design being made, as usually thought before speech, and in consequence, the design is related to its meaning, not necessarily to other designs that it resembles on a superficial level. This therefore also concerns the matter of the context attached to the terms and terminology employed by art historians and others in respect to a particular form, design and period, which, 
if then translated onto another period, tends to obscure the meaning and therefore our understanding of the meaning of a similar in appearance form or design, but which was made within different cultural-religious parameters and so understandably carries a different meaning. Discrimination is lost and therefore understanding is confounded if the same term/name is employed for designs/forms that superficially resemble each other but which carried different meanings), which may well be related to the initial letter $k a f$ in square kufi, which as a letter has been associated with Mount Khaf and with the Throne of the Almighty and was the letter used as an abbreviation for the Koran, or with $y a$, or to the letter haa in its isolated form, which, as a meaningful letter has been associated with weeping and with The Last, all letters which have forms in square kufi that resemble a s-like hook or its mirror image (Fig. 44); or for example, the design that is often described as a comb-tarak, to the letter sin written in square kufi, a letter which has been associated with the life bestowing (Schimmel, 1984, 153) (Allah), with humans, as also with the Sphere of Water; sometimes combined in a design to suggest Ya Sin, ياسين, one of the Prophet's names, as well as the name of the Sura in the Holy Koran, the letters Ya + Sin added together $=60=6+0=6$, that is the letter wav, meaning, 'and (Allah)'; while the letter wav also occurs, woven and embroidered in textiles, as is noted above (Figs. 12-17). Square kufi words and letters in kilim and carpet designs seems to have been employed in part at least, as a reminder of He, "who by the pen taught men" (Holy Koran, Sura 96, "Recite! Your Lord is the Most Bountiful One, who by the pen taught men what he did not know.", and with the earliest surviving Korans written in this script), and which seems to have been derived in part from the knowledge of the script used in the earliest Korans, in numerous public examples of square kufi on the exteriors of minarets, as on some turbe, on the coinage, its use in tiraz textiles and on palace carpets and ceramics, perhaps also from the importance attached to the 13 unconnected initial letters, mukette'at at the start of twenty nine Sura of the Koran: Alif, Lam, Mim, Sad, Ra, Kaf, Ha, Ya, 'Ain, Ta, Sin, Qaf and Nun, together with the three Sura that are named with a single letter, Kāf (Khaf ) ص ص ص , Sad , and Nun نhen combined with the relative ease in employing this script in designs for woven material, as a reminder, explicit or implicit of the Word and so a sign of the Almighty, when compared to employing any of the more cursive scripts.

The problem of treading with feet, ritually clean or otherwise, on the Arabic inscriptions woven in carpets, and the legitimacy of weaving carpets or cloth with Arabic texts and words on them was addressed by a "fatwa", or legal religious ruling, issued by the Chief Kadi (judge) of Damascus, the Hanbalite scholar, Taj ad-Din al-Subki (d. 1371). He issued a fatwa forbidding their use (Rosenthal, 1971, 50-56, \& cited by Schimmel, 1984, 23. The fact that hadith record the Prophet frequently prayed wearing shoes suggests that there were no carpets at that time in the place of prayer). This fatwa leads one to suspect how common the practice of weaving and owning carpets with script on them was in $14^{\text {th }}$ century Mamluke territory, with inscriptions in Arabic, employing the same words and letters as were used in the revelation of the Koran, as well as Persian inscriptions, as noted above (see, Serjeant, 1972, 9; 51; 75; 97; 155-156 fn. 171; 203). This ruling, like so many others seems to have had only a certain impact, leading at times to the use of the "similitude-semblance" of particular words and scripts, rather than being completely legible with each letter of a word present and correctly marked and joined together, as was mentioned above in the case of the $14^{\text {th }}$ century "Marby" carpet, where the two Alifs of the Name "Allah", mirrored, are joined together and so, with these joined together bent back Alifs the word itself remains legible but is not entirely correct and as such reminds, being perhaps all the more potent for its proximity to the actual word, rather than being the word itself. However, some prayer (Eg. Topkapı Sarayı Müzesi, halı Env. no.: 13/2017 and no. 13/2040, both with both Kufi and cursive script) and other rugs, tents and textiles, including shrouds, tiraz, kilims (For the early $20^{\text {th }}$ c. kilims with Kufi script including verses from the 
Holy Koran, see for examples, Görğünay-Kırzıoğlu, 1999) and carpets for wall decoration and today t-shirts, continue to be produced carrying accurate legible kufi and other Arabic scripts and also Persian inscriptions, Koran texts, phrases and individual words, as well others carrying their approximate likenesses, serving as reminders down to the present day.

The name Ali in kufi script repeated 3 times (Fig. 45a/b), forming a repeat hexagonal design in cut tile work around the mihrab of the Akşehir Congregational Mosque of 1220-36 (Fig. 46); carved in stone, probably originally inlaid with glazed cut-tile work, on either side of the framing arch over the doorway in the exterior portal of the Aksaray-Konya Sultanhan of 1236 (Fig. 47); as also carved in stone on both sides of the right hand side mihrab-like niche in the portal of the Karatay Medrese, Antalya of 1250 (Fig. 48); can be "read", not only as the name Ali repeated 3 times within the hexagon, but also, given the absence of a cogent reason for this particular repetition to be employed on this structure - there is no evidence for example to suggest that Jelal ad-Din Karatay or Sultan Ala ed-Din Keykubat I in respect to the same design on the earlier Sultanhan, publicly publicised or propagated Shii'ite-Alid-Ali ilahi belief from the evidence from the historical record, inscriptions and buildings that they ordered constructed that this repetition, and perhaps any repetition, serves as an indication to the viewer of a change in the method of "reading", as in the difference in meaning between a single wav read simply as and, or as and (Allah), and a doubled wav read as Allah. Repetition it seems was employed at times as both a written and visual marker of meaning. The use of the same word written three times may also perhaps suggest the three indicated in the Koran as being the sum of that which is dual and that which is single, the totality, as also in $66=6+6=12=1+2=3$. Consequently, if one regards this repetition of the word Ali as serving to indicate a change in "reading" the text/design, from a literary to a numerical one, if the numbers representing the letters forming the name Ali, 110, are multiplied by 3 , for the 3 times that the word Ali is repeated within the hexagon, the result is 330 , and $3+3+0=6$; this being also the sum of the numbers given by the letters in the name Muhammed, 132, 1+3+2 =6; as also the sum of 114, being the number of Sura in the entire Holy Koran, while the number 6 is represented by the letter wav meaning, given the proximity of the mihrab-like shape, and (Allah). In consequence, this hexagonal design can be "read" as indicating, and (Allah), the sum of the letters of the name Muhammed, the sum of the number of suras in the Holy Koran and, recorded in the visible script the word Ali three times. While if one adds together the numerical values of the three Ali's in the hexagon, together with the 6 represented by the points of the hexagon, one obtains $6+6=66$, the doubled wav and the numerical equivalent of the word Allah. This was probably the primary reason why the designer chose to locate these two carved designs in this position, on either side of the mihrab-like niche, in the design supplied to the head architect-başmimar for execution by a master mason, as it forms an implicit reminder to those coming to or leaving the medrese, as of the Sultanhan, that, "To God belongs the East and the West, whichever way you turn, there is the face of God. God is omnipresent and all knowing" and, "Say, 'The East and the West are God's. He guides whom He will to a straight path"; while it seems the cut tile work repeat of this design around the mihrab in the Akşehir Congregational Mosque is to be read as a wav repeat, an, "and (Allah)", or as a doubled wav repeat, from the hexagon $=6+3 \mathrm{x}$ Ali $=6$; that is "read" as 66, and meaning, Allah, meaningful words written as a design within a meaningful pattern, within the 6 of the hexagon, for the eye to see and for the mind to "read", and so serving as visual "dhikr Allah".

\section{The $13^{\text {th }} \mathrm{c}$. palace tile of the crazy donkey-ass}

One final example of the meaning conveyed by the language of Islamic design comes from the $13^{\text {th }}$ c. tile-work of the Rum Seljuk palace of Kubadabat beside Lake Beyşehir. This palace was ordered by the Rum Seljuk Sultan Alaed-Din Keykubat I, and built under the supervision of his 
director of state buildings, Sadred-Din Köpek in the mid 1230's (Uyumaz, 2003, 99; Arik, 2000, 43-44), largely completed by 1236. The palace contained superb tile-work, figural, calligraphic and patterned, some of which is today on display in the Karatay Medrese in Konya (See for example, Arik, 2000; Duggan, 2006, where many of the figural tiles are related to the four armies of the Prophet Süleyman-Solomon, of men, animals, birds and jinn, Süleyman being the name of the founder of the Rum Seljuk dynasty in Anatolia and thereby forming an additional claim to legitimacy for rule, with the ruler often described as, "The Second Süleyman"; in addition to the official recognition of Rum Seljuk rulers as Sultans by the Abbasid Caliphs in Bagdad until 1258). One 8 pointed star tile shows us a mad-grinning donkey-ass-mule, together with opium seed pods (Fig. 49). A donkey-ass-mule is a most odd motif to find in the decoration on the walls of a palace. Why was this motif chosen and used in the tile-work of this palace, given that the word donkey is often employed in the Islamic world as an insult, its mention in educated company followed by, estağfurullah, asking pardon from the Almighty for mentioning it, what reason can there be for a donkey-mule-ass to have been depicted in the tile-work revetments covering the walls of a $13^{\text {th }}$ c. palace?

In his Mathnavi, Jelal ad-Din Rumi frequently uses the donkey-ass as an image or symbol of the unaware human being filled with vain desires and fantasies issuing from a variety of sources.

"O ass who have obstinately remained in asininity, how will you get scent of (apprehend) the (life-giving) breaths which resemble those of the Messiah? If a phantasy appear (in your heart), how will you know from what hiding place it springs forth? Ere (all) phantasies are swept from the inward part, the body will become (insubstantial) as a phantasy in (consequence of) renunciation" (Mathnavi, Book. 5, verse 2814; as also for example verses 2325, and $2326 \mathrm{ff}, 2517$ ).

This imagery also forms an essential element in the stories of Jelal ad-Din Rumi's near contemporary, Nasred-Din Hodja and his donkey, where the hodja's donkey is often to be read as a symbol representing the body and the hodja himself as the intellect - hodja and donkey are therefore often to be read and to be understood as being one single person, with the intellect at times riding and controlling the body, at other times not.

The taming of the body through renunciation as described by Jelal ad-Din Rumi above is likewise indicated by Nasred-Din Hodja: "The Mulla bought a donkey. Someone told him that he would have to give it a certain amount of food every day. This he considered to be too much. He would experiment, he decided, to get it used to less food. Each day, therefore, he reduced its rations". "Eventually, when the donkey was reduced to almost no food at all, it fell over and died"."Pity,' said the Mulla. 'If I had had a little more time before it died I could have got it accustomed to living on nothing at all" (Shah, 1976, 116).

The Hodja sitting on his donkey but facing in the opposite direction to the donkey, reminds us of the orientation of the body towards the worldly and of the intellect towards the Almighty, which requires the taming of the body's worldly desires and passions (Shah, 1976, 84), as is echoed in the story concerning if the reply of the body, that of the donkey, or the reply of the intellect, the Hodja, was acceptable to the questioner (Hikmet, 1959, 134); as likewise in the story of the donkey rushing off to some unknown destination with the Hodja clinging on, reminding of the passions of the body overwhelming the intellect (Shah, 1977, 174; Hikmet, 1959, 81); as also in the story of the Hodja losing his donkey (Shah, 1977, 116). More than three hundred years earlier, on the $26^{\text {th }}$ of March 922 there was in Bagdad the execution of Mansur al-Hallaj and it was said that at the time of the death of Mansur, that a mule (Kadri, 
2011, 219), that is the symbol of the body, had replaced that of the real Mansur, that is, the body died, Mansur lived.

Consequently the depiction of a rider-less donkey-ass-mule on this Rum Seljuk palace tile (As later the İlkhan Abu Sa'id employed the donkey symbol struck on coins minted at Sinope, see for examples Perk, \& Öztürk, 2003, 124-125, Res. 7.1) can therefore be "read" within its $13^{\text {th }}$ c. religious-cultural context, and it can be understood as symbolizing the body, the passions on the loose without the aid of the guiding intellect, this animal has no rider. The addition of the opium pods to the design on this tile pointing up the madness of the body, with all its worldly desires and passions. Rather than being just decorative tiles, the tiles from the Rum Seljuk Kubadabat Palace, like most traditional Islamic design work, be it in a mosque, medrese, hospital, palace, or other building, or covering the surface of smaller objects, materials and textiles, is "only decoration", if it is clearly understood that its function as decoration is in representing and indicating, of embodying on the surface of man-made objects, signs and reminders of knowledge and meaning, that these traditional design served and continue to serve to remind us, on a number of levels, of the reality, the actualité, depth and wonder of Belief and of the presence of the Almighty.

\section{Conclusions}

It can be understood that the motivating idea behind the creation and use of all Islamic design stems from a clear understanding of the implications for the believer of the explicit statement made in the Holy Koran, Sura Al-'Ankabut, 29:46, "Nothing is greater than the remembrance of God".

And also in, Sura Al-Baqarah, 2:153 "Keep Me, therefore, constantly in mind, I shall keep you in mind".

And again in Sura Al-Ra'd, 13:28, "Surely in the remembrance of God all hearts are comforted".

As also in Sura Al-Azhab, 33:21, "There is a good example in God's apostle for those of you who look to God and the Last Day and remember God always".

And in Sura Al-Azhab, 33:41, "Believers, be ever mindful of God: Praise him morning and evening" Udhkurullaha dhikran kathira.

Likewise ahadith that relate this same meaning and expand upon it include Baghawi in his Mishkat al-Masabih who records: "Abu al-Darda' reported God's Messenger as saying, "Would you like me to tell you the best and purest of your deeds in the estimation of your Lord, those which raise your degrees highest, those which are better for you than spending gold and silver, and better for you than that you should meet your enemy and cut off one another's head?" On receiving a reply in the affirmative, he said, "It is remembering Allah, the Exalted" (Nawawi, 1989, 240, no. 1446, Tirmidhi).

Likewise Abu Said related that God's Messenger said,"Even though he plied his sword amongst infidels and polytheists till it was broken and smeared with blood, the one who made mention of God would have a more excellent degree than he" (Peters, 1994, 16).

And the Hanbalite student of Taqi ad-Din Ahmad ibn Taymiyyah, Ibn Qayyim al-Jawziyya (1292-1350) records a hadith transmitted from al-Harith al-Ash'ari, "And He enjoins upon you the remembrance of God, Most High. Verily, the parable of that is a man who goes forth while his enemies are fast upon him, then comes to a safe fortress, where he delivers himself from them. In the same way, a servant shall not deliver himself from the Devil save by the remembrance of God, Most High” (al-Jawziyya, 2004, 22).

It is this imperative, "to remember God", to remember, to keep constantly in mind and 
always to recollect as far is humanly possible The One, which is the heart and the very essence of Islam, and, it is from the practice of this remembrance, not in any way any simple or any easy task, given the enormous distractions of this temporal world, particularly in the modern world today, and given the distractions of the passionate - the distracted speculative soul, the nafs, that all else of any real importance in this domain both stems and is validated. Consequently Islamic design, - calligraphy, motif, letter-number, colour and symbol - served and can continue to serve as an essential aid to this vital practice, by creating within our man-made environment a climate within which the recollection of the Almighty, the greatest of our human undertakings, is facilitated, and it can today include for example the designs printed on mass produced manmade objects of daily use such as matchbox covers and other objects, both large and small.

It is within this same context that the Mesnevi of Jelal ad-Din Rumi records a passage, which seems to have originated with ibn Arabi: "The house that is without a window is Hell; to make a window, O Servant of God, is the foundation of the true religion. Do not ply the axe in every thicket, Oh, come and ply the axe in excavating a window" (Mathnavi Book. 3, l. 2404-05).

The "axe" employed in this context being the remembrance of God and "the house" being, this temporal world and, at the same time, this particular human being of vain, distracted and forgetful fancy. And the window? Well the window when excavated allows access out from this imprisoning, finite temporal-material world, and can let inside inshalla that light which is greater than the sun, "Light upon light; God guides to His light whom He will".

Seljuk, Beylik and Ottoman design, along with all other truly Islamic design: the meaningful employment of motif and pattern, number and colour, as likewise of script, served and continues to serve in the visual domain as aids to this remembrance of God, as visual reminders of " $d h i k r$ Allah". This is why for example the word 'Allah' forms a border motif on some Seljuk carpets; while 'Muhammed', in a variety of Kufi scripts occurs frequently in the tile work on Seljuk minarets, the minaret like the manar being the marker, the sign of The One, the alif, the reminder of the vertical dimension as distinct from the worldly horizontal, the reminder of the upright (Jelalad-Din Rumi also alludes to the body of a believer (in Islam) as like a minaret, a straight, upright form Mathnavi 1982, Book. 6, v. 1145, that is like an Alif, hat-1 evvel, the first letter of Allah. This relationship believer-minaret-Alif, is unfortunately given an obscure interpretation by Blair, 2008, 11, where, in respect to the upright alif, she writes, "and often compared metaphorically, particularly by mystics, to a standing person who refused to prostrate". Rather, the upright believer prostrates only to the Almighty and refuses to prostrate to the temporal world, "As men by nature upright", Sura Al-Beyyinah, 98:5; "Is he who goes groping on his face more rightly guided, or he who walketh upright on a straight road?" Sura Al-Mulk, 67: 22), is combined with the name of the Almighty's last Prophet on this alif, the minaret being a reminder of The One and of the Prophet's recital learnt from Gabriel, as for example on the minaret of the İnce Minareli Medrese, Konya of 1258 (Fig. 50), and it is content of this nature which provides the meanings to the designs traditionally repeatedly employed in Islamic art, as an aid to the practice of this remembrance by the members of the community.

It seems reasonable therefore to suggest that the sooner this high art of meaningful design is restored to our man-made environment and to the surfaces of the objects in our daily use, the easier it will be for at least some of us to regain our state of recollected-ness of who and what we truly are in this caravanserai of two doors. As the adhan marks the day into five parts, just five audible reminders per day (Initially prayer was twice a day towards Jerusalem, Quran 50:39. Following the hijra to thrice, Quran 17:79, 52:49, towards Mecca in 624, 2:143-144 five times per day. The tradition related by Ibn Abbas states that during the Night Journey-Miraj the Prophet was initially told to institute prayers 50 times per day, indicating the importance of this practice of remembrance. At the instigation of the Prophet Musa-Moses, who thought this was 
too great a demand placed upon the Muslims by the Almighty, as the Jews were only obliged to pray twice a day, the number of obligatory prayers for Muslims was successively reduced by 5 , until only 5 remained and, from the end of the Prophet's Night Journey these five, from the original 50, became the Muslims' five obligatory, distinct from any number of supererogatory prayers in the course of a night and a day), so manmade objects carrying a surface covering of meaningful designs, in addition to Islamic calligraphy, mark and can serve to remind us within the manmade environment during the long hours between these audible reminders. The remembrance of God is work for the seeing eyes (In respect to the importance of seeing: "Say: "It is He Who has created you (and made you grow), and made for you the faculties of hearing, seeing, feeling and understanding: little thanks it is ye give", Al-Mulk, Sura 67:23; "The blind and the seeing are not alike”, Fatir, Sura 35:19; “can the blind be held equal to the seeing?” AlAnaam, Sura 6:50; "This is my way: I do invite unto Allah,- on evidence clear as the seeing with one's eyes,- I and whoever follows me. Glory to Allah! and never will I join gods with Allah!", Yusuf, Sura 12:108; "And We had firmly established them in a (prosperity and) power which We have not given to you (ye Quraish!) and We had endowed them with (faculties of) hearing, seeing, heart and intellect: but of no profit to them were their (faculties of) hearing, sight, and heart and intellect, when they went on rejecting the Signs of Allah; and they were (completely) encircled by that which they used to mock at!", Al-Ahqaf, Sura 46:26), the windows to the soul, as it is for the mind and ear and for the hand, as it is for the tongue and for the heart. It is therefore perhaps one the greatest tasks facing the Muslim community of today, to return once again, refreshed and renewed, these lost visual markers into our man-made everyday environment, in order to facilitate that greatest task for the individual believer, which is the remembrance of God; wa la dhikrullahi akbar.

"And prayer is more

Than an order of words, the conscious occupation

Of the praying mind, or the sound of the voice praying" (Eliot, 1942).

The antidote to the forgetfulness of mankind is dhikr, and dhikr, the act of remembrance, is both verbal and visual, through spoken or silent $d h i k r$, and through once again seeing, absorbing and reflecting upon, as inhabiting once again in the increasingly largely man-made environment of this modern world, a man-made environment of surfaces carrying the language of reminders and signs, that once again can carry refreshed, the same sense and meaning of the traditional designs formerly applied to the surfaces of materials, and which would thereby return visual reminders carrying significant meaning into our modern man-made environment; an environment which is otherwise composed of bare naked material, uninformed, unenlightened, untransformed, otherwise bare of clearly articulated spiritual content and in consequence, is leading us to inhabit "the world of appearances,", that is, "the house without a window," the imprisoning man-made temporal reality, un-reminded of, and so absenting ourselves from our responsibilities as those who have submitted, and denying ourselves access to 'The Light' that can be incurred through this remembrance. 


\section{REFERENCES}

Acar, B. B. (1982). Kilim, Cicim, Zili, Sumak Türk Düz Dokuma Yaygıları. İstanbul: Eren Yayınları

Addas, C. (1993). The Quest for Red Sulphur: The Life of Ibn 'Arabi. Cambridge: The Islamic Texts Society.

Aksoy, Ş., \& Milstein, R. (2000). “A collection of Thirteenth century illustrated Hajj certificates”. M. Uğur Derman 65th Birthday Festchrift. 101-134 . Ed. Cemil Schick. İstanbul: Sabancı University.

İbn Arabi, (2000). Harflerin İlmi. Çev. M. Kanık. Bursa: ASA.

Aref, A. El (1966). A Brief Guide to The Dome of the Rock and Al-Haram Al-Sharif, Jerusalem: The Supreme Awqaf Council.

Arberry, A. J. (1977). Discourses of Rumi. New York: Samuel Weiser.

Arık, R. (2000). Kubad Abad. Ankara: İş Bankası Yayınları.

Arnold, Sir T. W. (1965). Painting in Islam: A Study of The Place of Pictorial Art in Muslim Culture. London: Dover.

Aslanapa, O. (1988). One Thousand Years of Turkish Carpets. İstanbul: Eren Yayınları.

Atasoy N., \& Raby J. (1994). Iznik, The pottery of Ottoman Turkey. London: Alexandria Press.

Atıl, E. (1975). Art of the Arab World. Freer Gallery of Art Washington D.C.: Smithsonian Institution.

Atıl, E. (1987). The Age of Süleyman the Magnificent. New York: Harry N. Abrams.

Austin, R. W. J. (1971). Sufis of Andalusia: The Rūh Al-quds and Al-Durrat Al-fäkhirah of Ibn 'Arabī. London: Allen \& Unwin.

Barışta, H. O. (1999 Ekim). Karaman Taşkale Halıları. ERDEM, Halı Özel Sayısı-1 Cilt:10, Sayı:28, 4348. Ankara: AKM.

Barkırer, Ö. (2000). Onüç ve Ondördüncü Yüzyıllarda Anadolu Mihrapları. Ankara: Türk Tarih Kurumu Yayınları.

Bayrak al-Jerrahi al- Halveti, Sheikh T. (1985). The Most Beautiful Names. Vermont: Threshold Books.

Bennett, I. (1977). Teppiche der Welt. München: Mosaik Verlag.

Bernardi, G. (2007). Monete cufiche. Appunti per la lettura. Trieste, Bernardi, 2007.

Bierman, I. A. (1998). Writing Signs: The Fatimid Public Text. London: University of California Press.

Birol, İ. A., \& Derman, Ç. (2001). Motifs in Turkish Decorative Arts. İstanbul: Kubbealtı.

Black, A. (2001). The History of Islamic Political Thought. New York: Routledge.

Blair, S. S. (1998) Islamic Inscriptions. New York: New York University Press.

Blair, S. S. (2008). Islamic Calligraphy. Edinburgh: Edinburgh University Press.

Bosworth C. E. (1977). The Later Ghaznavids. New York: Columbia University Press.

Brend, B. (1991). Islamic Art. London: British Museum.

Brown, J. P. (1968). The Darvishes or Oriental Spiritualism. London: Frank Cass.

Browne, E. G. (1997). A Literary History of Persia: From the Earliest Times Until Firdevsi. Vol. 1, Maryland: Iranbooks.

Bulut, L. (1994). “Kabartma Desinli Samsat Ortacağ Seramikleri”. Sanat Tarihi Dergisi VII 1-18. İzmir: Ege Üniversitesi.

Burckhardt, T. (1989). Mystical Astrology according to Ibn 'Arabi. Trans. B. Rauf, Abingdon: Beshara.

Busbecq, O. G. de (2001). Turkish Letters. Trans. Edward Seymour Forster. Introduction P. Mansell. London: Sickle Moon Books.

Busbecq, O. G. de (1927). The Turkish Letters of Ogier Ghiselin de Busbecq Imperial Ambassador at Constantinople 1554-1562. Trans. E. S. Forster. Oxford: Clarendon Press.

Çaycı, A. (2002). Anadolu Selçuklu Sanatı’nda Gezegen ve Burç Tasvirleri. Ankara: Türk Tarih Kurumu Yayınları.

Chittick, W. C. (1994). Imaginal Worlds: ibn al-'Arabi and the problem of religious diversity. Albany: Suny.

Clevenot, D., \& Degeorge, G. (2000). Ornament and Decoration in Islamic Architecture. London: 
Thames \& Hudson.

Caiger-Smith, A. (1985). Lustre Pottery: Technique, Tradition and Innovation in Islam and the Western World. London: Faber \& Faber.

Çağlıtütüncügil, E. (Ekim 1999) Cami Tasvirili Yahyalı (Kayseri) Halıları. Halı Özel Sayısı-1, Cilt:10, Sayı:28, 87-83. Ankara: AKM.

Degeorge, G., \& Porter, Y. (2002). The Art of the Islamic Tile. Paris: Flammarion.

Derman, M. U. (1998). Letters in Gold: Ottoman Calligraphy from the Sakıp Sabancl Collection. İstanbul: Los Angeles County Museum of Art, Exh. Cat.

Duggan, T. M. P. (2006). 'The motifs employed on Rum Seljuk 13th century eight pointed star tiles from Antalya Province and elsewhere in Anatolia: an interpretation'. ADALYA IX, 149-219.

Durul, Y. (1987) “Türk Kilim Motifleri”. Türk Kültürünü Araştırma Enstitüsü, Yay: 62 Seri: V; Sayı: A. 3, Ankara.

Eliot, T. S. (1942). Little Gidding-in Four Quartets. 1944. London: Faber \& Faber.

Erbek G. (1990). Kilim Catalogue No:1, İstanbul: Selçuk A.S.

Ettinghausen, R., \& Graber, O. (1994). The Art and Architecture of Islam 650-1250. Newhaven \& London: Yale University Press.

Falk, T. (1985). Treasures of Islam. Exh. Cat. Geneva: Phillip Wilson Publications.

Al Ghazali, (1992). The Ninety-Nine Beautiful Names of God: al-Maqsad al-asna fi sharh asma'Allah alhusna. Trans. D. B. Burrell \& N. Daher. Cambridge: The Islamic Texts Society.

Görgünay-Kırzıoğlu, N. (Ekim 1999). "Yazılı Bardız Kilimi”. ERDEM, Halı Özel Sayısı-1I, Cilt:10, Sayı:29, 321-6, Resim 1-6. Ankara: AKM.

Goodwin, G. (1992). A History of Ottoman Architecture. London: Thames \& Hudson.

Grohmann, A. (1955-56). "Anthropomorphic and Zoomorphic Letters in the History of Arabic Writing". Bulletin de l'Institut d'Égypte, 38, 117-22.

al-Jawziyya, Ibn Qayyim (2004). The Invocation of God: Al-Wabil al-Sayyib min al-Kalim al-Tayyib. Trans. M. A. Fitzgerald, \& M. Y. Slitine, Cambridge: The Islamic Texts Society.

Hikmet, M. (1959). One Day the Hodja. Ankara: Tarhan.

Hillenbrand, R. (1999). Islamic Art and Architecture. London: Thames \& Hudson.

Hillenbrand, R. (2005). Islamic Art and Architecture. London: Thames \& Hudson.

Hitti, P. K. (1991). History of the Arabs. London: Macmillan.

Irwin, R. (1997). Islamic Art. London: Laurence King.

Kadri, S. (2011). Heaven on Earth: A Journey through Shari'a Law. London: The Bodley Head.

Karatepe, İ. (2008). Askeri Müze Bayraklar ve Sancaklar Koleksiyonu. İstanbul: Askeri Müze ve Kültür Sitesi Komutanlı̆̆ı.

Kayıpmaz, F., \& Kayıpmaz N. (1999 Ekim). “Anadolu Köy El Halılarının Gelenekli Tasarım Alışkanlıkları ve Aykırı Bir Üslup”. ERDEM, Halı Özel Sayısı-II, 10 (29), 369-74, 489-93. Ankara: AKM.

Klopsteg, P. E. (1987). Turkish Archery and the Composite Bow. Manchester: Simon Archery Foundation

Mackie, L. W. (1980). 'Rugs and Textiles'. Turkish Art, 301-73. Ed. E. Atıl, New York: Smithsonian Institution Press-Harry N. Abrams.

Mardrus, J. C., \& Mathers, P. (1996). The Thousand Nights and One Night. Vol. 2. London \& New York: Routledge.

Mercanlıgil, M. (1960). EBCED Hesabı. Ankara.

Miles, G. C. (1952). "Mihrab and 'Anazah: A study in early Islamic Iconography". Archaeologica Orientalia in Memoriam Ernst Herzfeld, 156-171. New York: Locust Valley.

Jokisch, B. (2007). Islamic Imperial Law: Harun-Al-Rashid's Codification Project. Berlin, Germany: Walter de Gruyter.

Imam Nawawi, (1989). Gardens of the Righteous: Riyadh as-Salihin. Trans. M. Z. Khan. London: Curzon Press. 
Nizami, (1924). Haft Paikar (The Seven Beauties). Trans. C. E. Wilson, London, Vol. 1. London: A. Probsthain.

Ögel, S. (1994). Anadolu’nun Selçuklu Çehresi. İstanbul: Akbank Yayınları.

Ögel, S. (2002). “Anadolu Selçuklu mimarisinda Taş Süsleme”. D. Kuban. Selçuklu Çağında Anadolu Sanatı, 311-28. İstanbul: Yapı Kredi Yayınları.

Öney, G. (1992). Anadolu Selçuklu Mimari Süslemesi ve El Sanatları. Ankara: İş Bankası Kültür Yayınları.

Öney, G. (1980). 'Bauschmuck und Kleinkunst'. Ed. E. Akurgal. Kunst in der Türkei, 176-214. Fribourg: Edition Popp.

Peters, F. E. (1994). A Reader on Classical Islam. Princeton, New Jersey: Princeton University Press.

er-Ravendi, M. b. Ali b. Süleyman (1999). Rahat-üs-Sudur ve Ayet-üs Sürur. Cilt II. Çev. A. Ateş, Ankara: Türk Tarih Kurumlarl.

Ettinghausen, R. (1984). Islamic Art and Archaeology. Ed. Rosen-Ayalon Collected Papers. Ed. M. Rosen-Ayalon. Berlin: Gebr. Mann Verlag.

Rosenthal, F. (1971). "Four Essays on Art and Literature in Islam”. The L. A. Mayer Memorial Studies in Islamic Art and Archaeology, II. Leiden: E. J. Brill.

Rumi J. (1982). The Mathnawi of Jalalud'din Rumi. Books I-VI. Trans. R. A. Nicholson. Cambridge: Gibb Memorial Trust,

Rumi J. (1977). Selected Poems from the Divani Shemsi Tabriz. Trans. R. A. Nicholson, Cambridge: Cambridge University Press.

Padwick, C. E. (1969). Muslim Devotions, A Study of Prayer-Manuals in Common Use. London: S.P.C.K. Perk, H., \& Öztürk, H. (2003). “XIV. Yüzyılın ilk yarısında Anadoludaki İslam Paralar üzerinde görülen bir kısım damgalar”. VII. Ortaçağ ve Türk Dönemi Kazı ve Sanat Tarihi Araştırma Sempozyum 7-9 Nisan 2003, 118-126. İstanbul, Mimar Sinan Üniversitesi Yayınlarl.

Peters, F. E. (1994). The Hajj: The Muslim Pilgrimage to Mecca and the Holy Places. Princeton: Princeton University Press.

Porter, V. (1995). Islamic Tiles. London: British Museum Press.

Renard, J. (1996). Seven Door to Islam: Spirituality and the religious life of Muslims. Berkley: University of California Press.

Serjeant, R. B. (1972). Islamic Textiles: Material for a History up to the Mongol Conquest. Beirut: Libraire du Liban.

Schimmel, A. (1984). Calligraphy and Islamic Culture. London and New York: New York University Press.

Shah, I. (1976). The Exploits of the Incomparable Mulla Nasrudin. London: Pan.

Shah, I. (1977). The Pleasantries of the Incomparable Mulla Nasrudin. London: Pan.

Treadwell, L. (2005). "Mihrab and 'Anaza or Spear-in-Sacrum?: A reconsideration of the iconography of an early Marwanid silver drachm”. Muaqarnas, 22, 1-28

Uyumaz, E. (2003). Sultan I. Alaeddin Keykubad Devri Türkiye Selçuklu Devleti Siyasi Tarihi (12201237). Ankara: Türk Tarih Kurumu Yayınları.

Williams, J. A. (1962). Islam. New York: George Braziller.

Wilson E. (1992). British Museum Pattern Books. Islamic Designs. London: British Museum Publications.

Yakıt, İ. (1992). Türk-İslam Kültüründe EBCED Hesabı ve Tarih Düşürme. İstanbul: Ötüken Yayınları. 


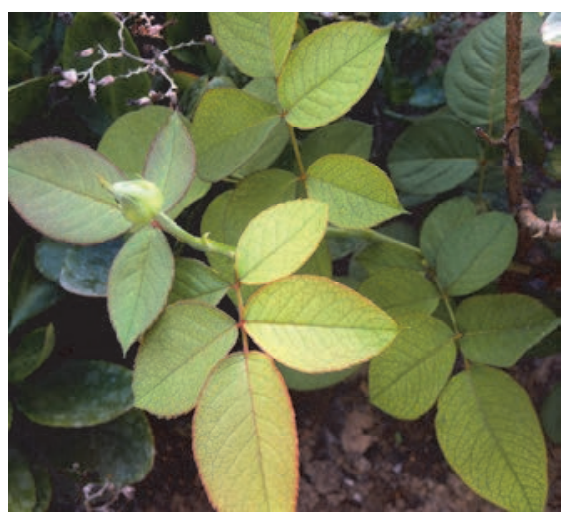

Figure 1. 3-5-7 leaves and the rose bud which can be read as $3+5+7=15$, which reads $5+1=6$ which equal the letter wav meaning, and (Allah). The rose bush reading therefore, Muhammed (the rose) and Allah.

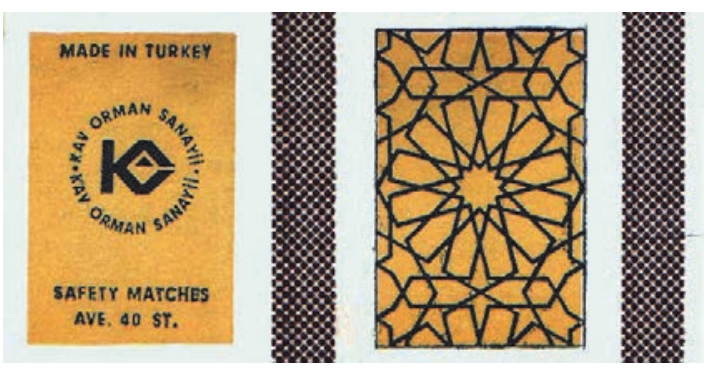

Figure 3. Seljuk-Beylik "kafes" design on KAV 1980's matchbox.

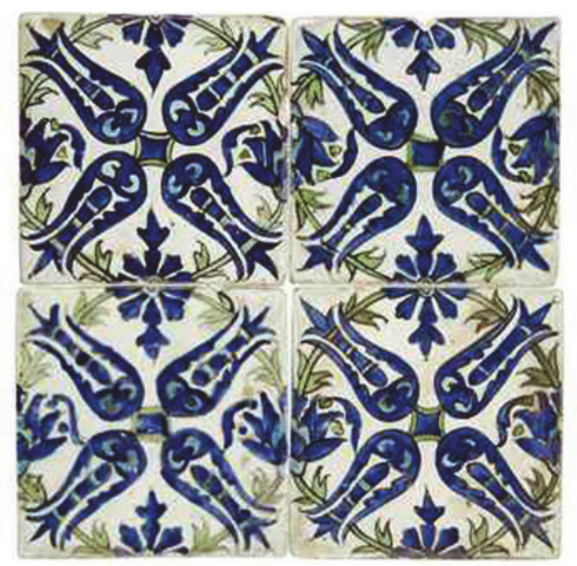

Figure 5. Tulips on four $17^{\text {th }}$ c. Ottoman Damascus tiles. (Sold Christies 2011).

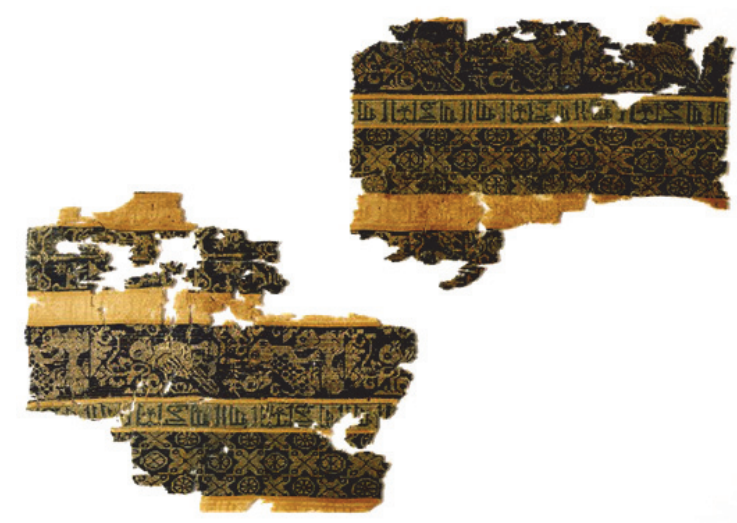

Figure 2. Example of tiraz. Inv. No. 10.14-251992-David Collection. The Arabic inscription in Kufi reads, al-mulk l-illah ("sovereign power belongs to God").

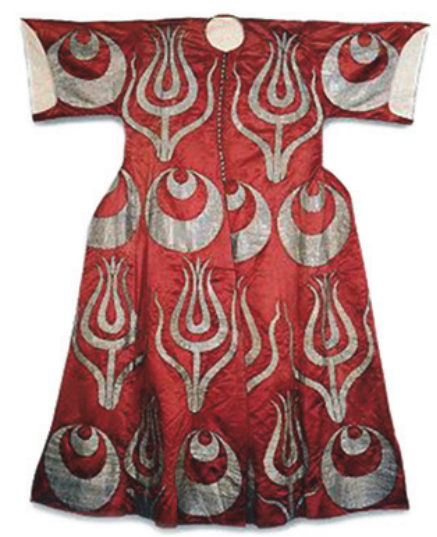

Figure 4. Tulips and crescent moons on kaftan, Topkapı Palace Col., İstanbul. Tulip=lale=66; Crescent moon=hilal= 66 .

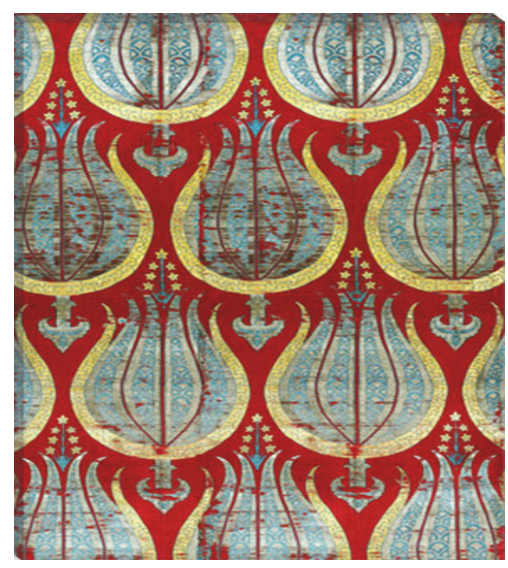

Figure 6. Tulips-lale $=66$ and crescent moons, hilal $=66$, woven in a $16^{\text {th }}$ c. Ottoman silk. 


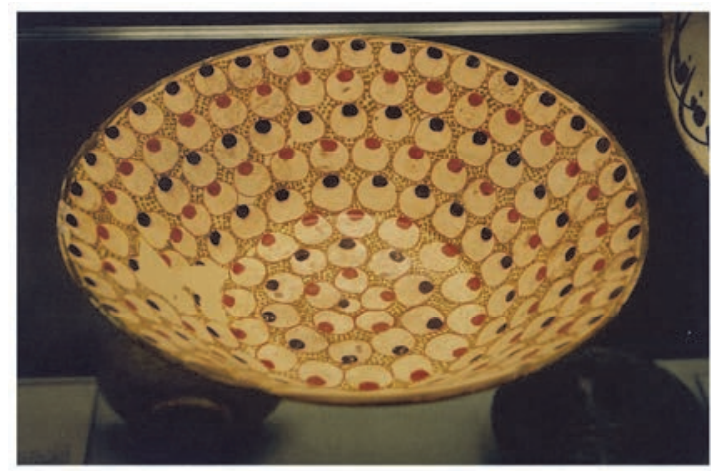

Figure 7. A crescent moon repeat pattern painted on a Nishapur $10^{\text {th }}$ c. bowl, V\&A, London, Inv. No. 1945-10-19264.

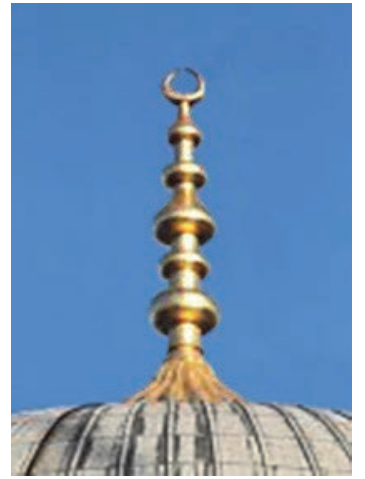

Figure 8. Crescent moon, alem crescent moon= hilal=66 and so can be read as signifying Allah.

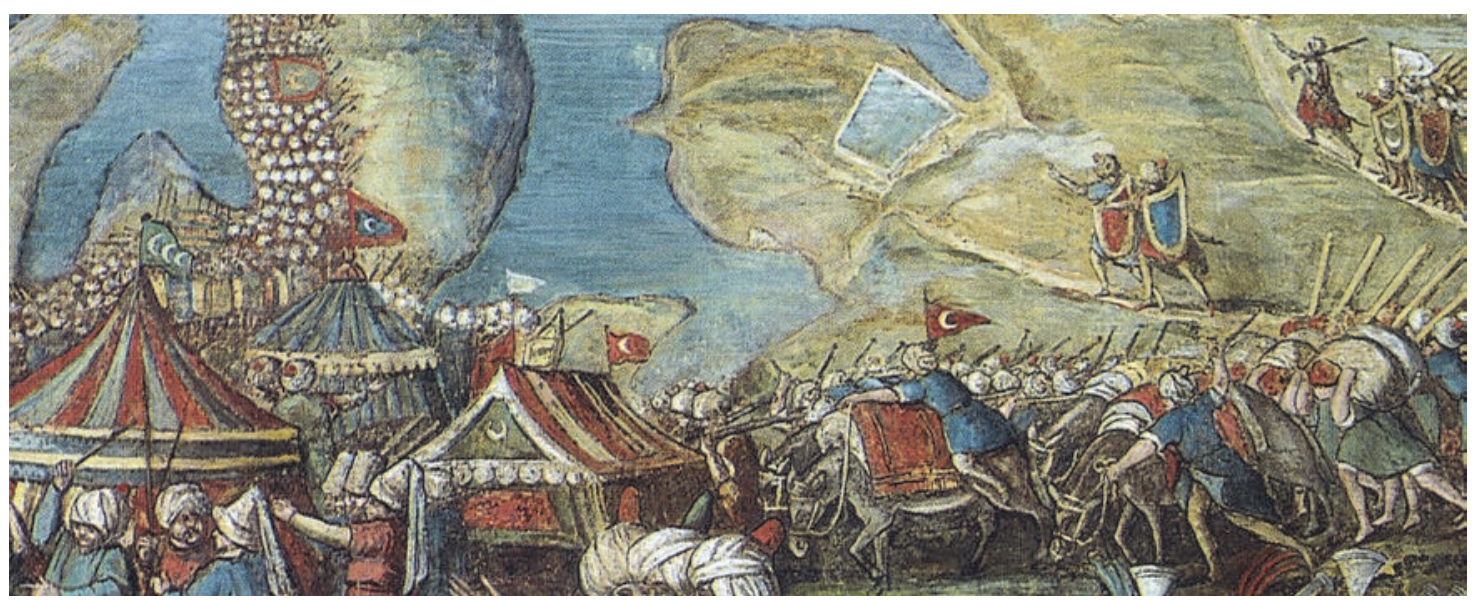

Figure 9. Crescent moons on Ottoman flags and tents. Detail from the 1570's painting of the 1565 Siege of Malta by Matteo Perez D’Aleccio, in the Grand Master's Palace, Valletta, Malta.

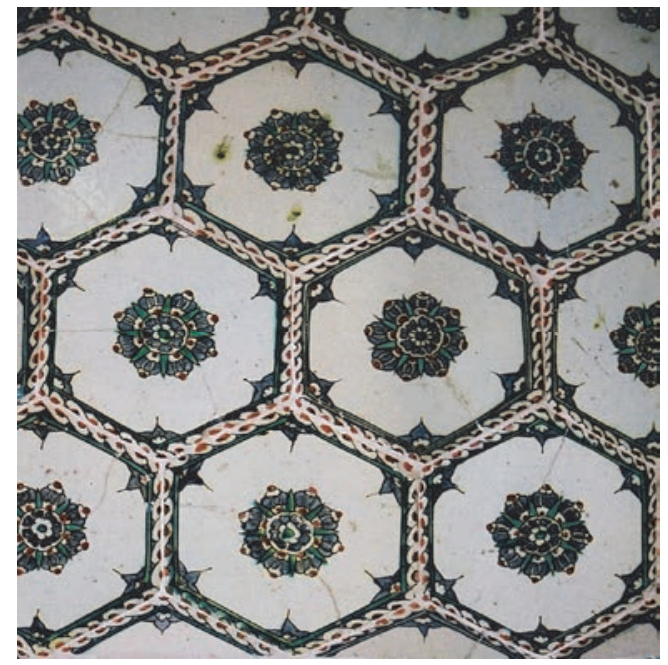

Figure 10. Revetment of hexagonal tiles, a rose within each hexagonal tile, Emanat-1 Mukaddese, TSM, İstanbul.

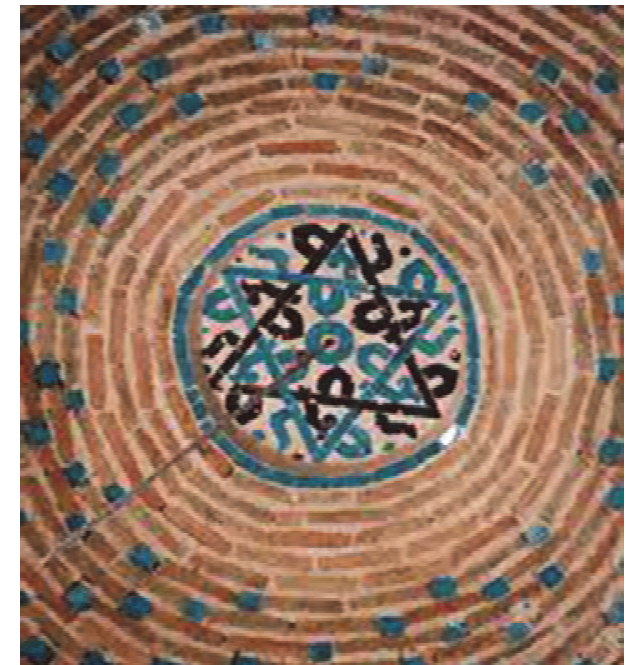

Figure 11. Interior of the dome of the Seljuk Ulu Camii, Eski Malatya. 6-pointed star and 6 times in kufi, Muhammad. It can consequently be read as 66=Allah. 


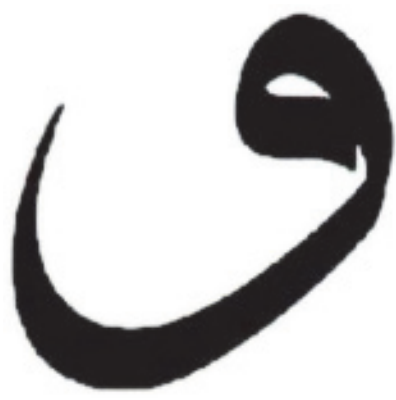

Figure 12. The letter wav, meaning, And=6. As also, And (Allah).

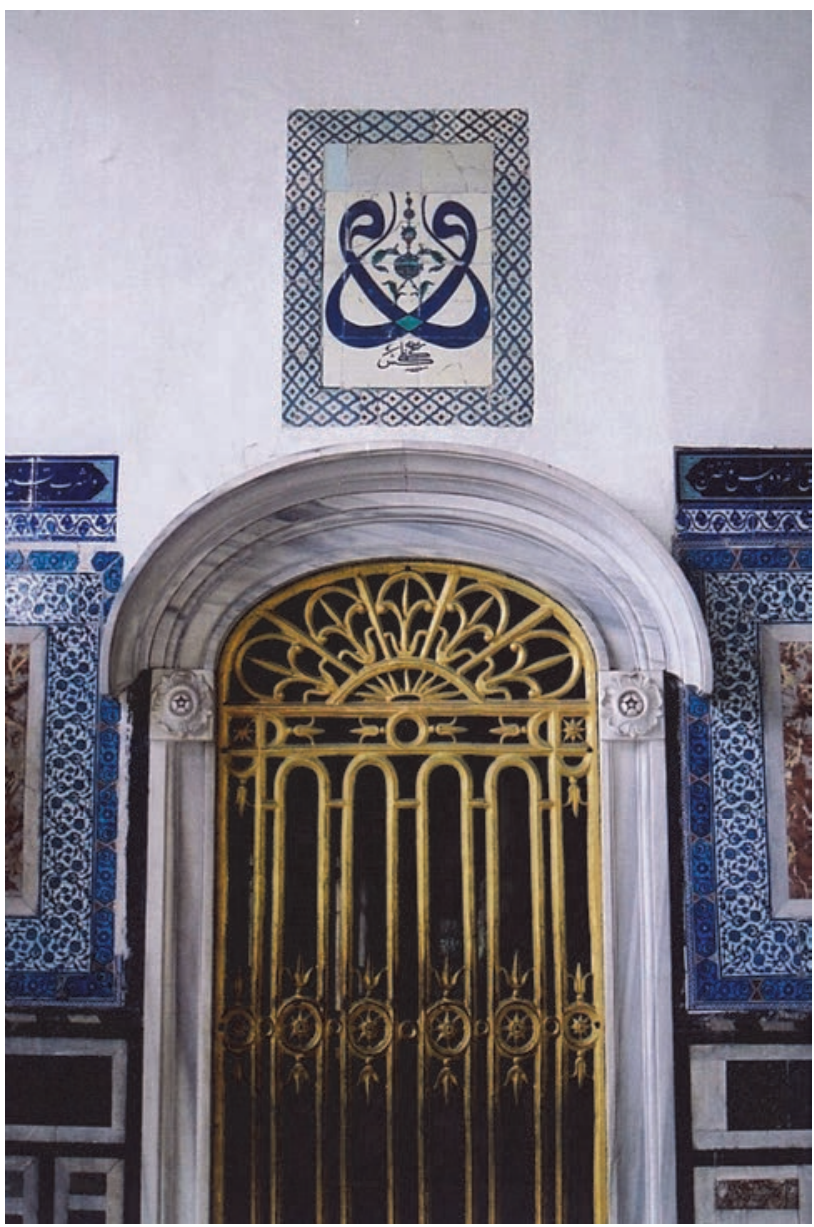

Figure 14. Wav mirrored on tile work, exterior of chambers housing the Emanat-ı Mukaddese, TSM, İstanbul.

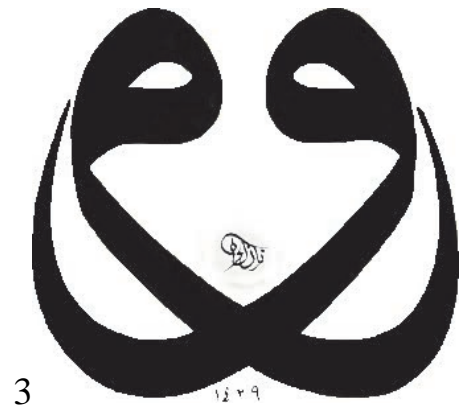

Figure 13. Mirrored wav letter, 6 \& 6=66.

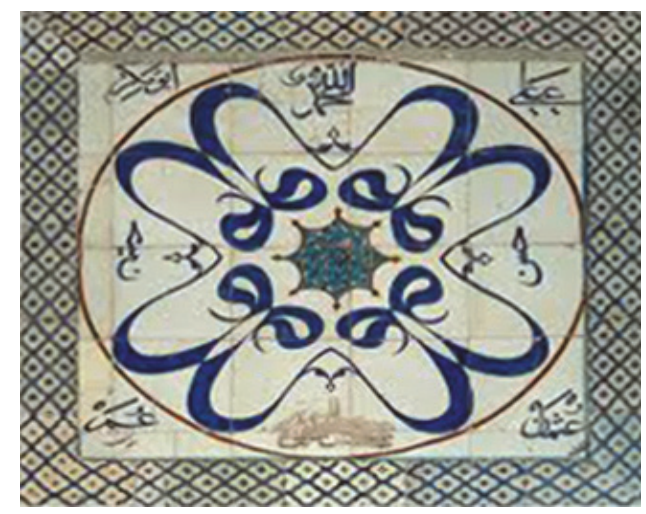

Figure 15. Tilework of 4 mirrored wavs, TSM, Istanbul. Which can be read as $6+6=$ Allah repeated 4 times.

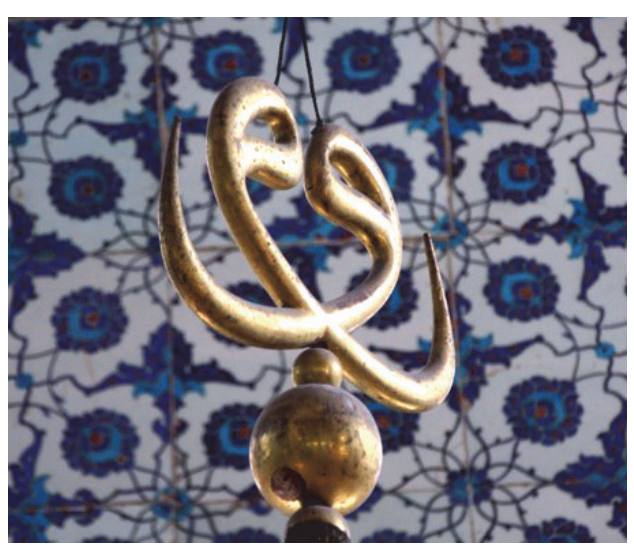

Figure 16. Sculpture of the letter wav, mirrored $=6+6=66=$ the 66 of the letters forming the word Allah, hanging suspended in Enderun Ahmet III library, TSM. İstanbul. 


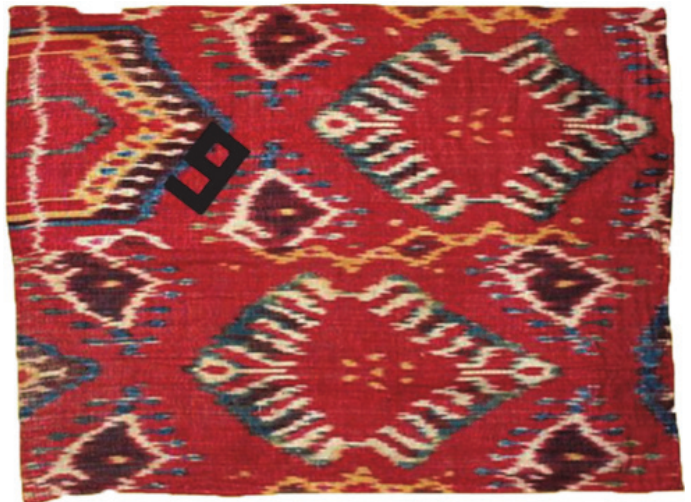

Figure 17. Wav letter repeated and mirrored on a Central Asian ikat silk fragment.

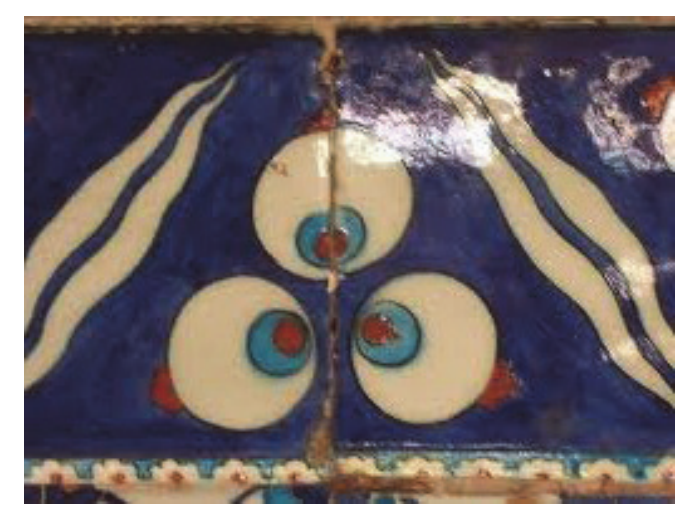

Figure 19. Crescent moons in groups of 3's. İznik $16^{\text {th }}$ c. tile border work, İstanbul.

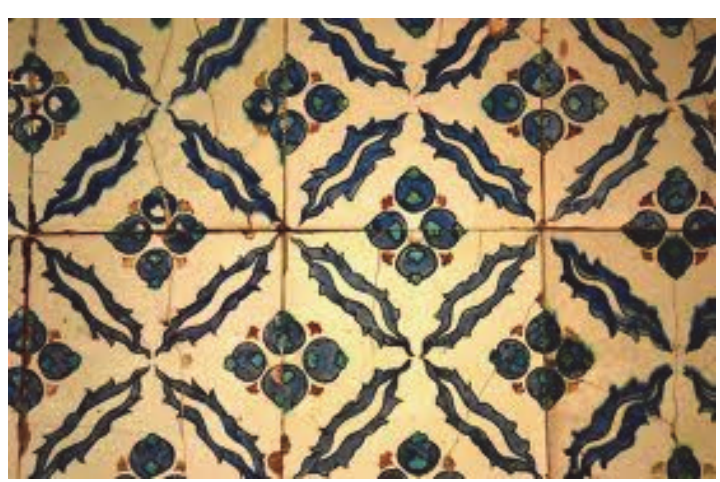

Figure 21. Tile revetment of crescent moons in fours.

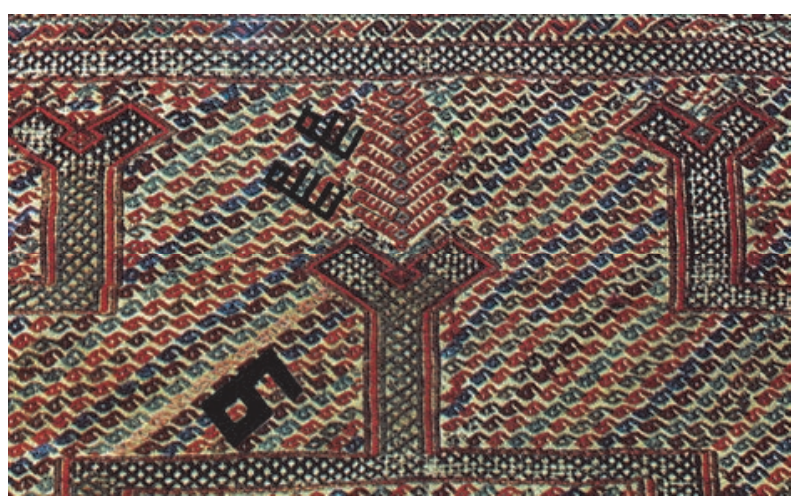

Figure 18. The letter wav in a woven repeat, and, Allah and Sanat, on a Keçimuhsin Köyü, seccade. Figure 16 in Kilim-Cicim Zili-Sumak, B. B. Acar, İstanbul. Eren Yayıncılık.

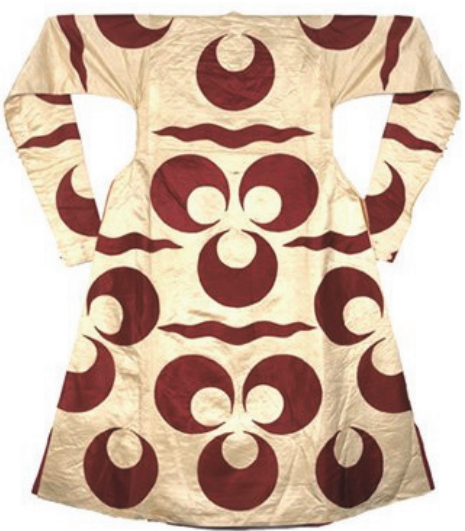

Figure 20. Crescent moons in 3's. Ottoman kaftan, TSM, İstanbul. Hilal $=66 \times 3=198=$ the name of the Prophet Yacub-Jacob.

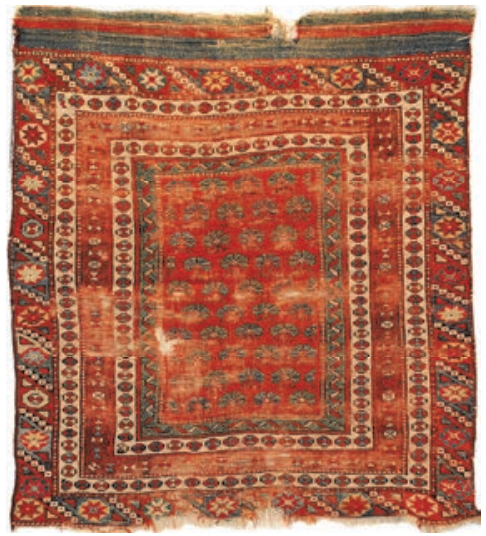

Figure 22. 40 carnations in centre field, 33 stars in the border, Bergama-Döşemealtı, 333 x33= 99 and 40 representing the many Names of God. 


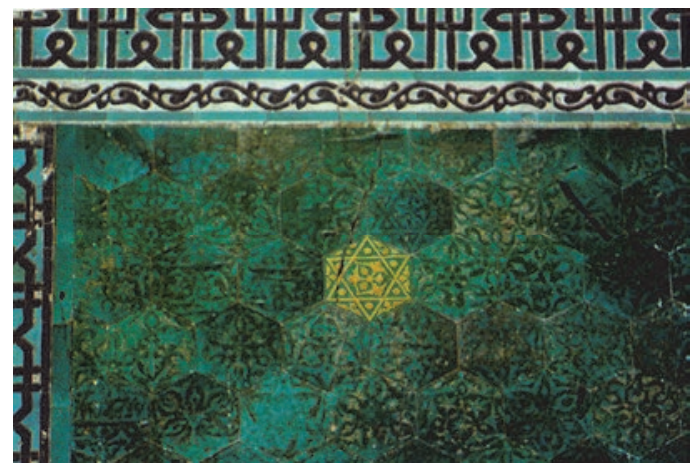

Figure 23. Seljuk hexagonal-6 pointed tiles, 1251, Karatay Medrese, Konya.

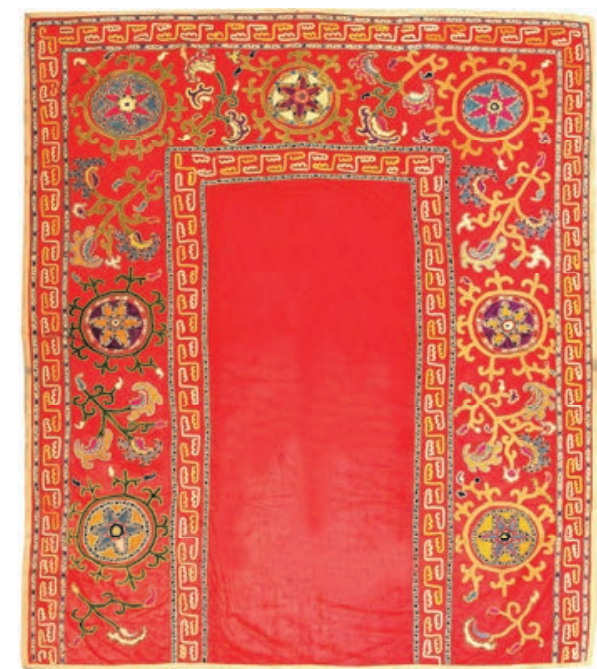

Figure 25. Central Asian Susani of a mihrab with a border of 7 roundels.

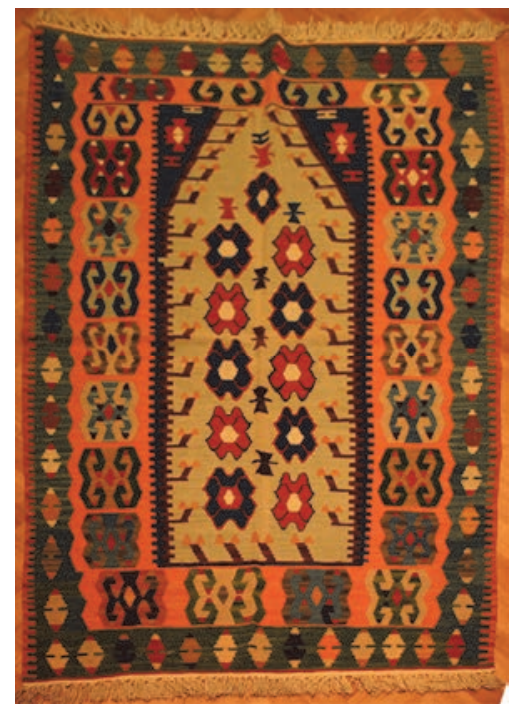

Figure 27. 11 rose-like beads in mihrab, 50 beads in the outer border, Durukök kilim, seccade, Kayseri.

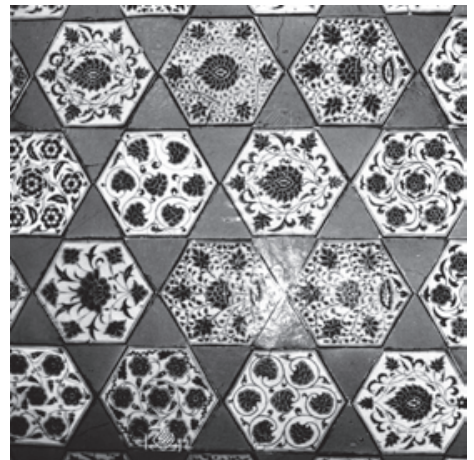

Figure 24. Hexagonal and triangular tile revetment. $6+6$ triangles $=66$. Muradiye, Edirne.

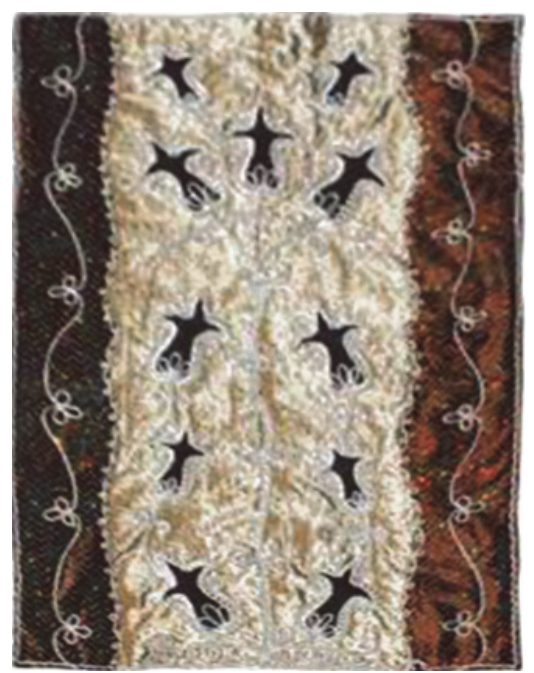

Figure 26. 11 motifs in the mihrab of a Pullu seccade in 3 colours, Kayseri.

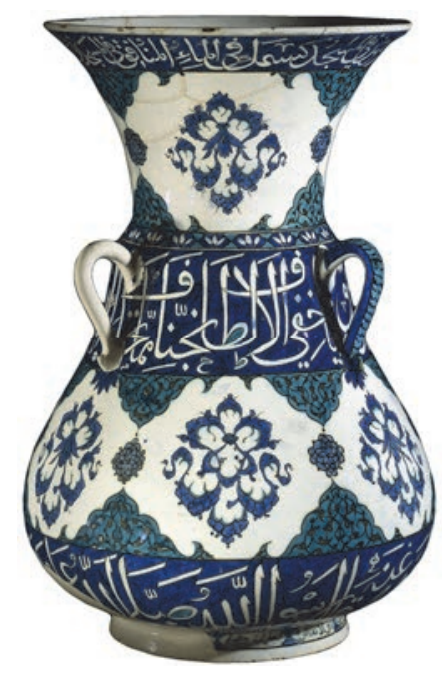

Figure 28. İznik $16^{\text {th }}$ c. symbolic mosque lamp. 


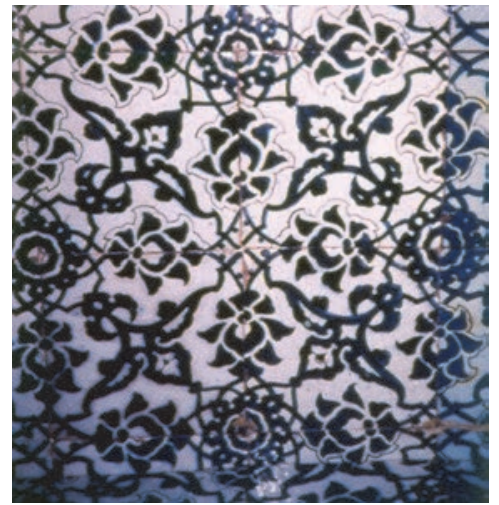

Figure 29. Ramazanoğlu Camii-Adana c. 1540 tile revetment of the 4 Archangels.

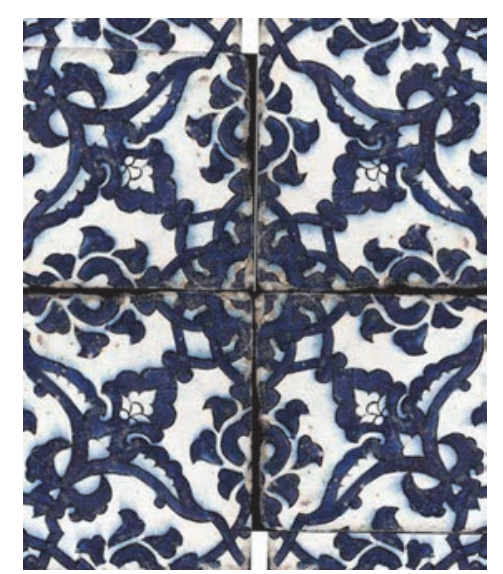

Figure 31. The 4 Archangels tiles from the Dome of the Rock.

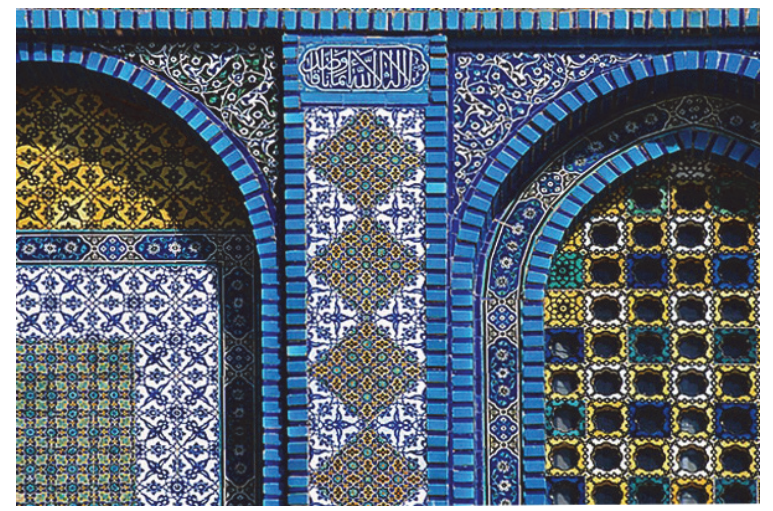

Figure 30. Archangel tiles on the exterior of the Dome of the Rock, Jerusalem.

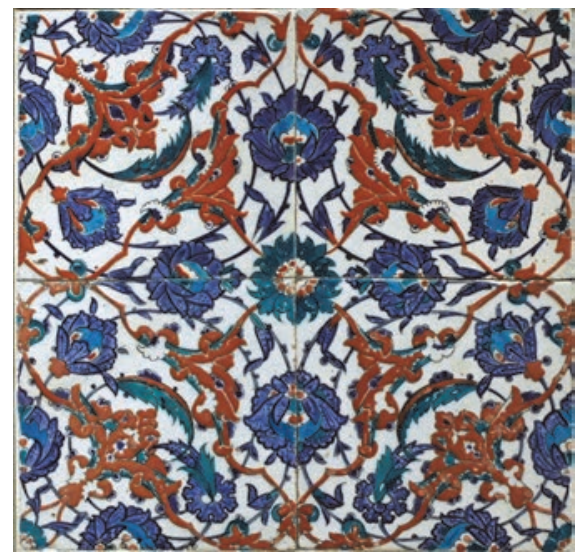

Figure 32. Reworked Archangel tile panel. Ottoman, $16^{\text {th }}$ c. İznik. (catalogued as flowers) Louvre No. OA3919-2-297.

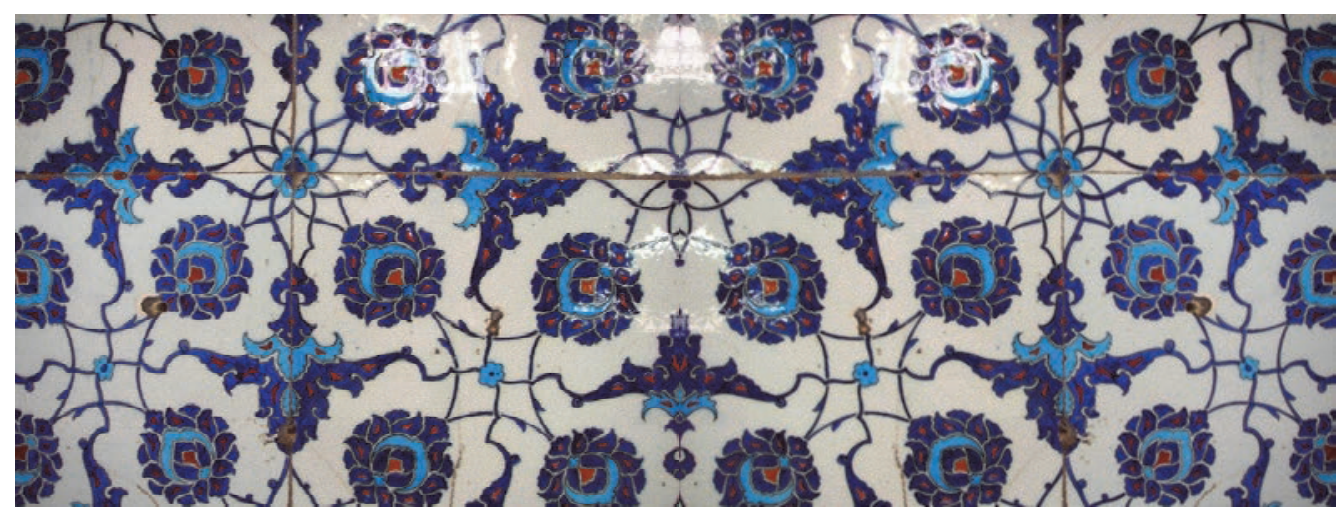

Figure 33. Reworked tilework pattern of the 4 Archangels, İznik, Enderun-Ahmet III Library, Topkapı Palace, İstanbul. 


\section{WD OVR AP

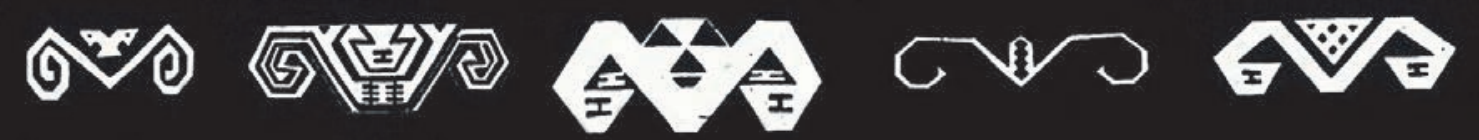

Figure 34. So-called rams horns motifs from Kilim Catalogue No1 prepared by Güran Erbek 1990.

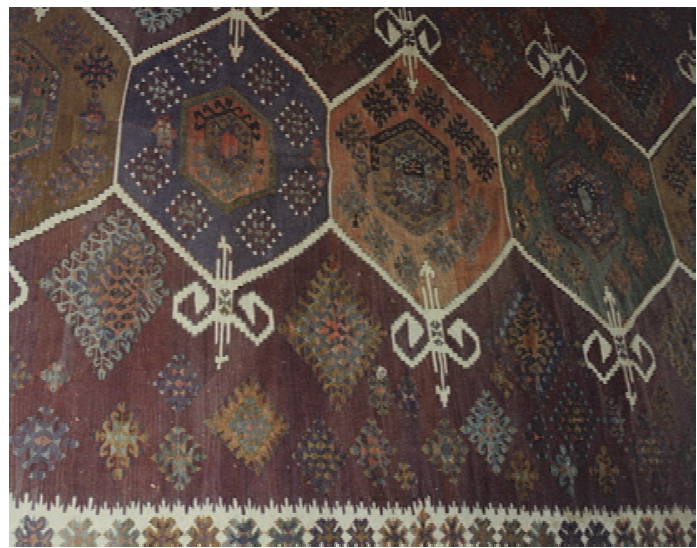

Figure 35. Bows, with siper, arrows and targets on a 10 arrow-On Ok Kilim

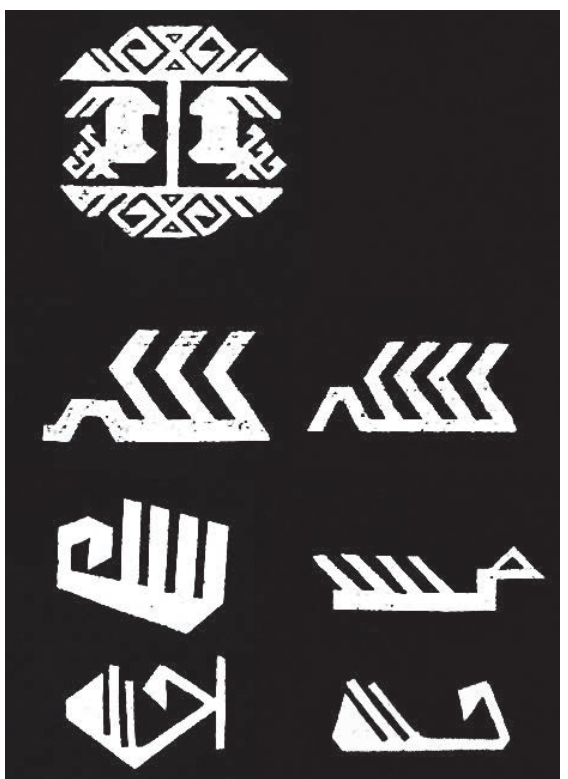

Figure 37. So-Called Birds-Kuşlar motif from Kilim Catalogue No. 1 prepared by Güran Erbek, 1990. Kufi script.

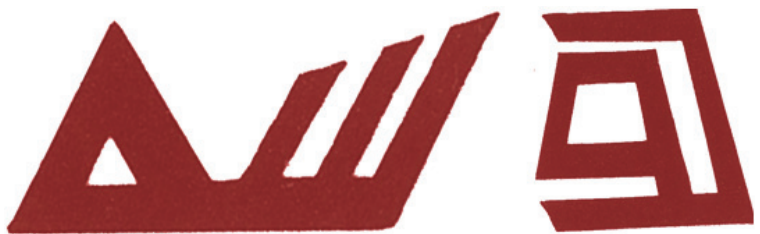

Figure 36. So-called "Sarkoy kilim motifs", Kufi Allah \& Alif +wav

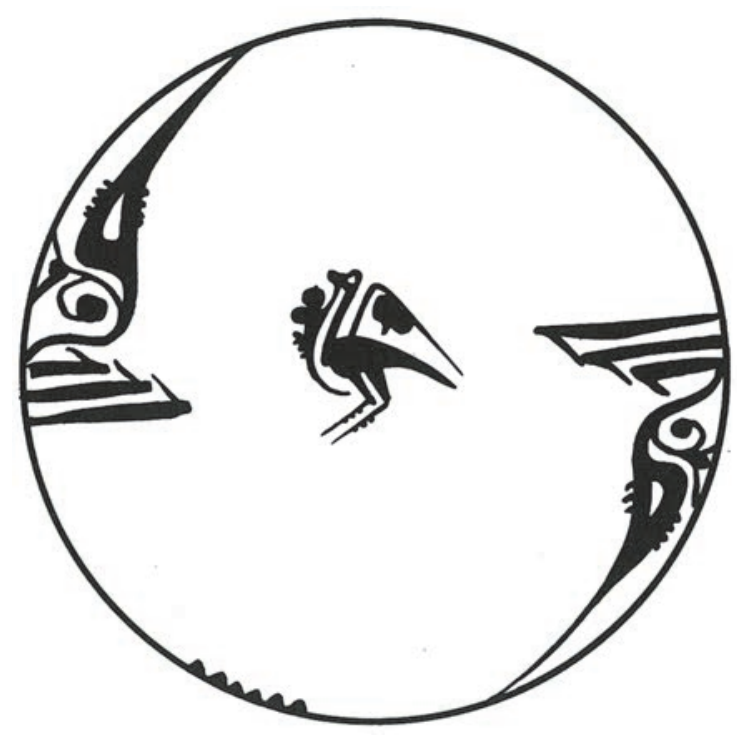

Figure 38. Allah written on either side of a $10^{\text {th }} \mathrm{c}$. Iranian bowl in the form of a bird, from $\mathrm{E}$. Wilson, 1992, Islamic design. 


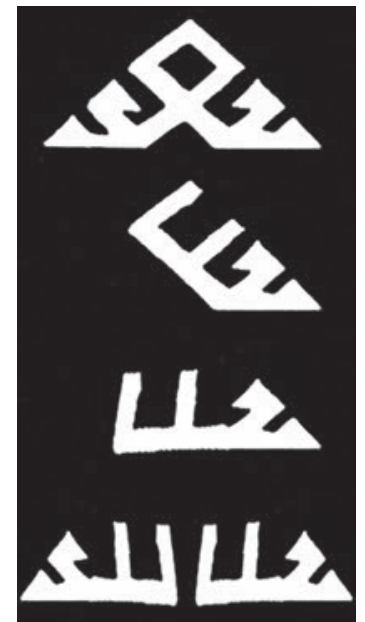

Figure 39. The so-called Eli Belinde motif. Kilim Catalogue No. 1 prepared by G. Erbek, 1990, Mirrored kufi Allah.

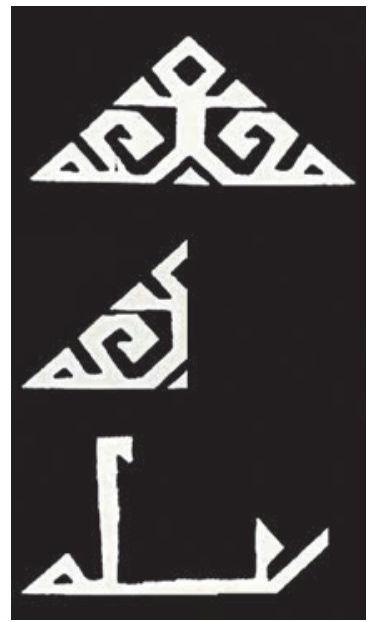

Figure 40. The so-called Eli Belinde motif. from Kilim Catalogue No. 1 prepared by G. Erbek, Mirror kufi, Allah.

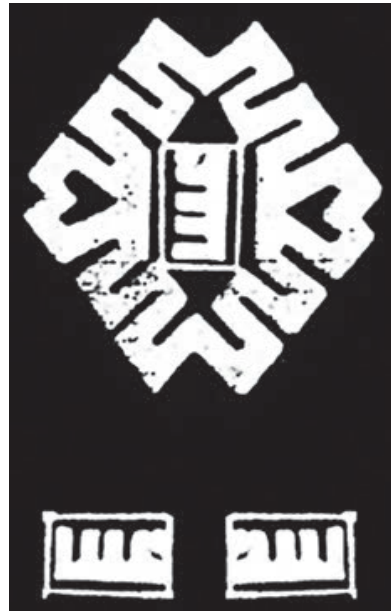

Figure 40a. So-called Pitrak motif From Kilim Catalogue No1 prepared by G. Erbek. The mirrored kufi word, Allah.

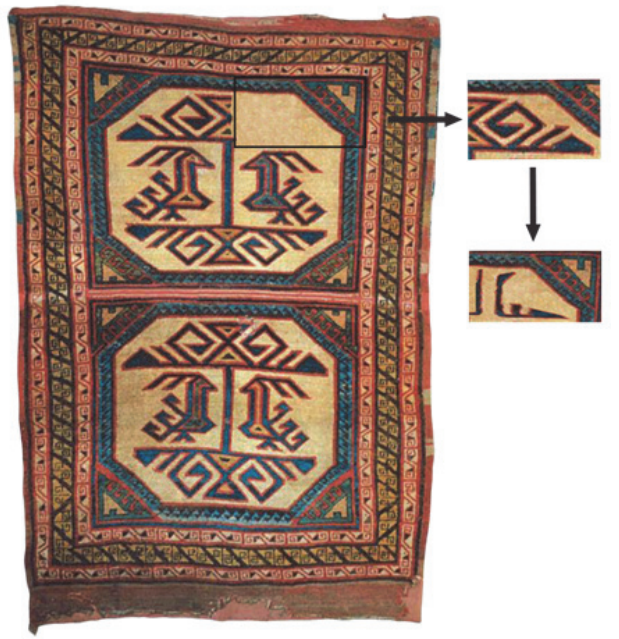

Figure 41. The mirrored kufi Allah on the $14^{\text {th }}$ c. Marby carpet.

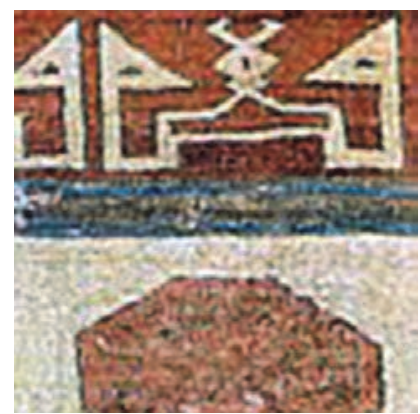

Figure 43. Li-Sa border design Konya Seljuk carpet, Türk İslam Eserleri Müzesi.

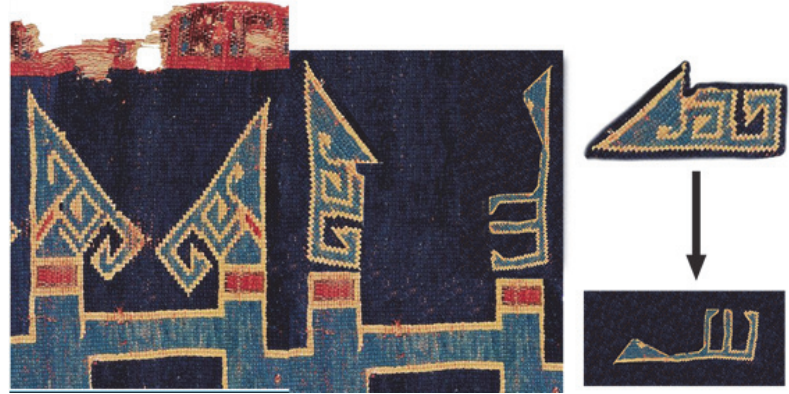

Figure 42. Seljuk $13^{\text {th }}$ c. Konya carpet, each horned Alif containing the Name Allah.

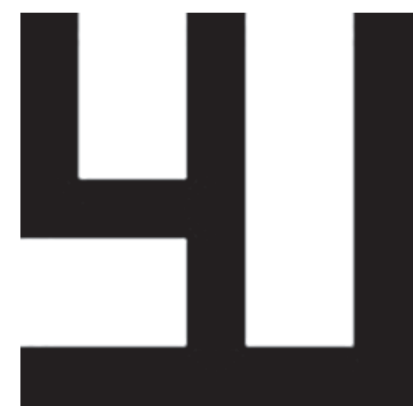

Figure 44. The word Ali in square kufi script. The letters giving the numerical total of 110 . 


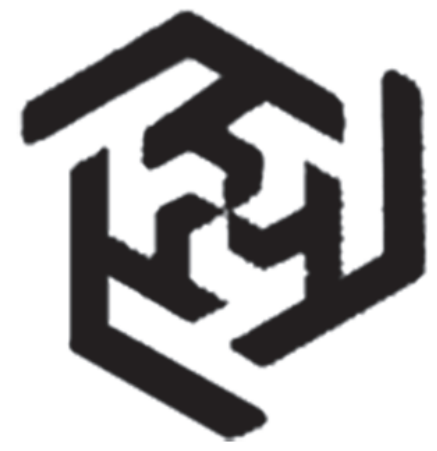

Figure 45. The word Ali repeated 3 times in kufi script forming a hexagon. Ali $=110 \times 3=$ $330=3+3+0=6$ represented by the letter wav, meaning, and (Allah), while the wav + hexagon can be read as $6+6=66$.

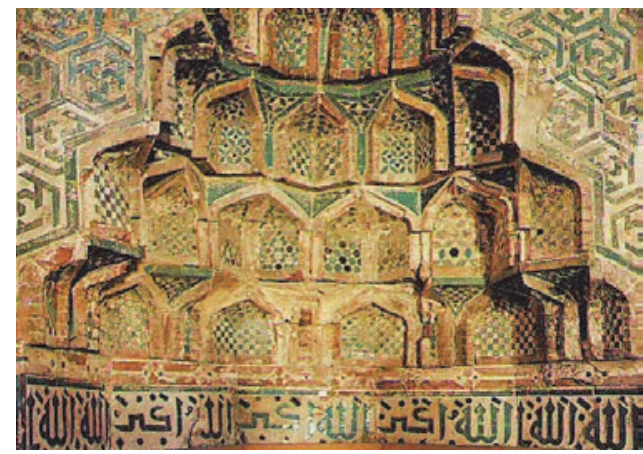

Figure 46. Seljuk tile mosaic Ali repeat around the mihrab, Akșehir Ulu Camii. Ali $=110 \times 3=$ $330=3+3+0=6$ which is represented by the letter wav, meaning - And (Allah), while the wav + hexagon can be read as $6+6=66$.

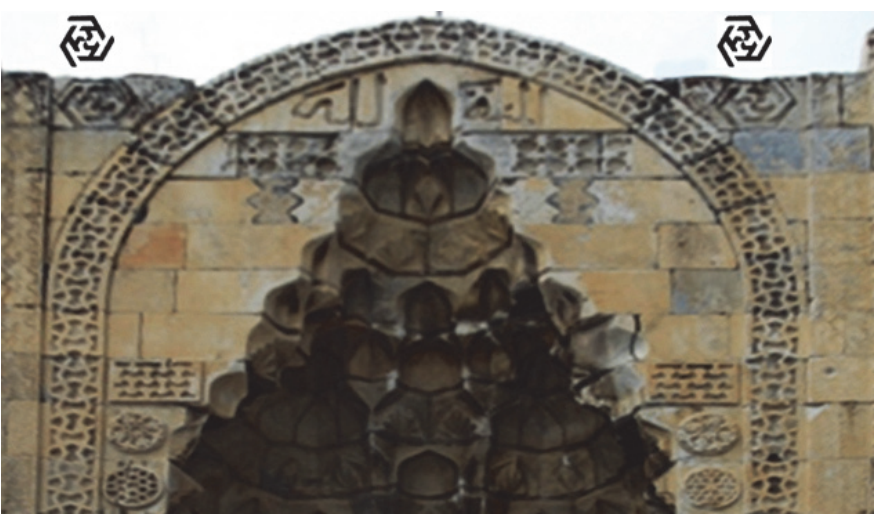

Figure 47. Aksaray Sultanhanı, Ali carved 3 times in kufi forming a hexagon, on either side of the arch of the main portal.

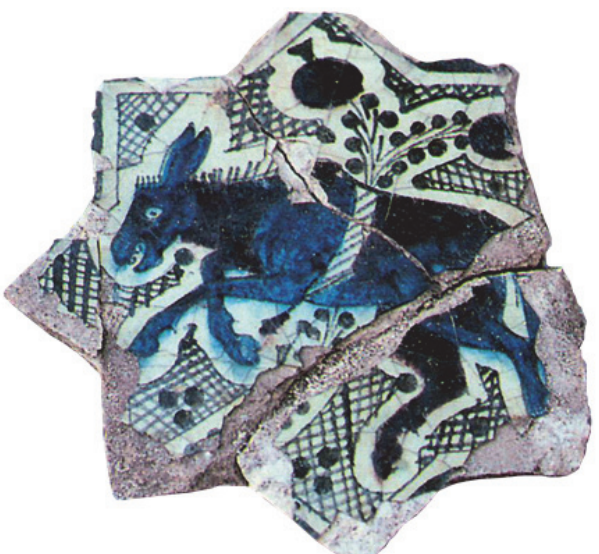

Figure 49. 8 pointed star tile with donkey and opium pods from the Kubad abad Palace, Beyşehir, c. 1236.

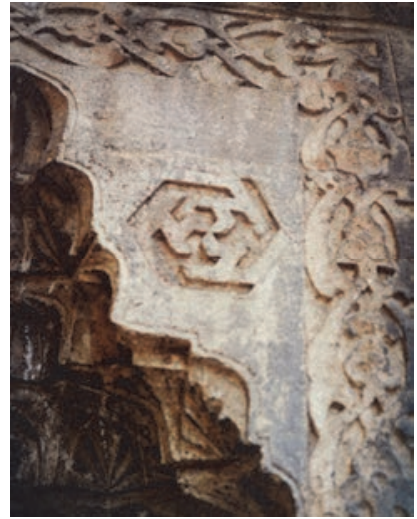

Figure 48. Ali carved 3 times in kufi, Karatay Medrese Antalya, forming a hexagon, on either side of the portal mihrab.

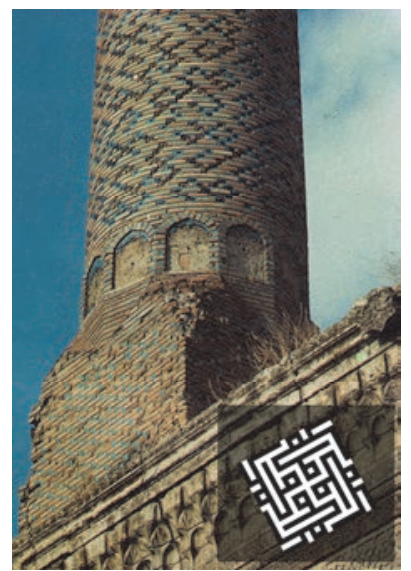

Figure 50. İnce Minareli Medrese, Konya of 1258 , square kufi cut-tile mosaic, the Word, Muhammad. Inset Square kufi Muhammed repeated 4 times in a square. 
